Artigo original

Hegemonia - Revista Eletrônica de Relações Internacionais do Centro

Universitário Unieuro

ISSN: $1809-1261$

UNIEURO, Brasília, número Especial, 2016, pp. 121-174.

Recebido em: 2/4/2016

Avaliado em: $1 / 5 / 2016$

Aprovado em: 9/6/2016

\title{
El Hinterland Sudamericano en su Trágico Laberinto Fluvial: Reconstrucción Biogeográfica y Etnopolítica o
} su Hilo de Ariadna (Segunda Parte)

Eduardo R. Saguier ${ }^{1}$

Resumen: La integración de las cuencas hidrográficas, la globalización del mercado interior, la recuperación de la memoria histórica por parte de los grupos étnicos avasallados, la integración etno-lingüística, la internacionalización de las hidrovías interiores y la construcción de obras hidráulicas en istmos o varaderos --cruciales para la navegación fluvial-cumpliría entonces los sueños de un mar dulce interior surcado por múltiples, entrelazadas y competitivas hidrovías, que incrementaría el potencial económico, demográfico, lingüístico, y turístico de todo un sub-

\footnotetext{
${ }^{1}$ Doutor em História. Docente e pesquisador do Museo Roca-CONICET. El autor agradece la contribución cartográfica y digital del Arquitecto e historiador José Antonio Hoyuela Jayo Director del Seminario (TERYSOS, Valladolid, España).

Cabe consignar que este trabajo no hubiera sido posible sin el apoyo moral e intelectual de mi esposa María Cristina Mendilaharzu, de amigos como Juan Méndez Avellaneda y Mariana Canale Oliver, y de los parroquianos de un popular café palermitano. Asimismo, cabe relatar que este trabajo fue el feliz derivado de una obra colectiva centrada en la construcción de un relato historiográfico para una eventual audiovisual a elaborar, que luego fue deslizándose al estudio de la fiebre cauchera del siglo XIX, y desde este al boom del narcotráfico en el siglo XX, y finalmente, merced al conocimiento de los ríos de la cuenca amazónica recayó en los descubrimientos de Ernesto Baldasarri, Horacio Gallart y Gabriel del Mazo acerca de la frustrada vía hídrica entre Manaos y Buenos Aires. Y finalmente, las vías hidrográficas nos llevaron a tomar conciencia de la relevancia política de los grupos étnicos existentes en la amazonía y el chaco, a la íntima conexión entre los mismos, y eventualmente a la "raza cósmica" de la que nos hablaba Vasconcelos.
} 
Artigo original

Hegemonia - Revista Eletrônica de Relações Internacionais do Centro

Universitário Unieuro

ISSN : $1809-1261$

UNIEURO, Brasília, número Especial, 2016, pp. 121-174.

continente y que les otorgaría a sus pueblos una motivación política y una política exterior que excedería intereses meramente regionales o nacionales. En la práctica concreta de los pueblos ancestrales de la Amazonía, la prolongada convivencia cotidiana ha venido erosionando las identidades nacionales, las antiguas identidades étnicas y cosmológicas, y las tradicionales prácticas endogámicas, estimulando una nueva identidad socio-regional chaco-amazonense con sus propios idearios e instituciones colegiadas e incluso nuevas identidades lingüísticas, culinarias, farmacológicas, simbólico-rituales, habitacionales y artísticas (canto, danza, música y pintura), y nuevos modos de pensamiento, de tradiciones y de entender la vida.

Palabras claves: Etnopolítica, etnocosmogonía, ancestralidad, comunalismo, enclave regional, silvícolas, caboclos, indigenismo, cuencas hidrográficas, hinterland amazónico, laberinto fluvial, dualismo geográfico, peregrinación mística, frontera populista, obras hidráulicas, hidrovías, etno-botánica, hibridaciones internas, sincretismos chamánicos, mar dulce interior, operación "Fitzcarraldo", cabotaje interior, familia extensa poligámica, mesianismo animista chamánico, objetos rituales, máscaras y bastones ceremoniales, politización de la etnicidad, geografización de la etnicidad.

\section{Apéndice-A.-Circuito laberíntico fluvial en el espacio amazónico- platino (Mapa I)}

A los efectos de un minucioso análisis etnográfico e hidrográfico que corroboren las tesis e hipótesis arriba enunciadas, debemos configurar como corpus histórico-geográfico una red de cursos fluviales o laberíntico espacio en el hinterland amazónico, que configura una curva ondulatoria irregular; ${ }^{2}$ es decir un circuito sumamente complejo compuesto por seis 
Artigo original

Hegemonia - Revista Eletrônica de Relações Internacionais do Centro Universitário Unieuro

ISSN: $1809-1261$

UNIEURO, Brasília, número Especial, 2016, pp. 121-174.

(6) corredores o circuitos principales, que recogen las aguas de diecisiete (17) grandes afluentes (de más de mil km de longitud cada uno), y estos a su vez de más de un millar de sub-afluentes, íntimamente ligados entre sí, pero muy diferentes en materia hidrológica, económica, demográfica, étnica, artística y cosmológica.

Estos seis (6) corredores o circuitos, que solo en el Amazonas alcanzan a veinte mil km navegables, son sucesivamente de sur a norte y siguiendo las agujas del reloj, el tramo boliviano amazónico terraplenado y elevado con sus cuatro (4) afluentes del Itenéz/Guaporé, el circuito amazónico peruano endogámico y monolingüe con sus cuatro (4) grandes afluentes (Urubamba, Tambo/Apurimac, Marañón/Ucayali, Napo), el tramo amazónico colombiano exogámico y multilingüe y el corredor brasileño septentrional con sus tres (3) grandes afluentes (Putumayo/Ica, Caquetá/Japurá y Negro), el circuito amazónico brasileño y caboclo, de la margen derecha del río Amazonas, con sus siete (7) grandes afluentes (Javary, Juruá, Purús, Madeira, Tapajós, Xingú, y Tocantins-Araguaia) que recogen el tráfico de los ríos procedentes de los macizos charqueño y central brasilero-platino, el circuito fluvial brasilero meridional o frontera populista (Guaporé), y por último el circuito fluvial paraguayoplatino de la peregrinación mística. Asimismo, el circuito fluvial amazónico ondulatorio debe contemplar necesariamente itinerarios laberínticos de ida y de vuelta, así como los trayectos locales río arriba y río abajo. ${ }^{3}$

\footnotetext{
2 Ver Fonseca Gadelha, 2002.

3 http://3.bp.blogspot.com/-YxtY3xjQ88s/VV_1fEvKKpI/AAAAAAABHo4/yVoX8yA700/s1600/200906_mapa\%2BRIOS.jpg
} 
Artigo original

Hegemonia - Revista Eletrônica de Relações Internacionais do Centro Universitário Unieuro

ISSN : $1809-1261$

UNIEURO, Brasília, número Especial, 2016, pp. 121-174.

Para consumar el intrincado cabotaje fluvial de todo el circuito, o Hilo de Ariadna del laberinto sudamericano, se puede iniciar en cualquiera de los seis (6) tramos, desde la Amazonía boliviana a Manaos, hasta Buenos Aires o Montevideo; o viceversa desde Buenos Aires y Montevideo hasta Corumbá y Manaos (Brasil), Mocoa y Florencia (Colombia), El Coca (Ecuador), Iquitos, Pucallpa y Puerto Maldonado (Perú), y Cobija y Trinidad (Bolivia). Para ello es preciso remontar los seis (6) corredores amazónicos mencionados siguiendo un curso de rotación fluvial en el sentido de las agujas del reloj, que atraviese en dirección sur-norte los ríos de llanura de Bolivia, los ríos de montaña del Perú, y en dirección oeste-este los ríos de Ilanura selvática de Colombia; o cortando camino bajando un río de llanura brasileño, el río Madeira, en dirección a Manaos; y en dirección norte-sur los ríos de llanura del Alto Paraguay y Paraná.

Y en el circuito inverso, de vuelta o retorno, el cabotaje fluvial circularía en sentido contrario a las agujas del reloj, desde Manaos (Brasil) hasta el Alto Paraguay (Brasil) y el Río de la Plata, recogiendo en dirección nortesur el tráfico que baja de los ríos de llanura brasileños de la vertiente meridional del Amazonas, el tráfico que baja de los ríos de llanura de Ecuador y Colombia (Napo, Putumayo, Caquetá, Negro), atraviesa los ríos de montaña del Perú, y los ríos de llanura de Bolivia. O, alternativamente, el cabotaje fluvial podría cortar camino remontando ríos de llanura como los ríos Madeira, Guaporé y Alegre, hasta alcanzar los ríos Aguapey, Jaurú y el Alto Paraguay mato-grossenses.

A todos los que practican estos laberínticos y borgianos cursos de agua les deberían asistir los derechos soberanos de libre tránsito, flujo o 
Artigo original

Hegemonia - Revista Eletrônica de Relações Internacionais do Centro Universitário Unieuro

ISSN: $1809-1261$

UNIEURO, Brasília, número Especial, 2016, pp. 121-174.

circulación a través de ambos estuarios y cuencas, el del Plata y el del Amazonas, garantizados por las normas del derecho internacional público que estipulan la libre navegación de los ríos, y el derecho a exigir la construcción de obras de infraestructura que viabilicen la interconexión entre cuencas fluviales antagónicas.

\section{A-I.-Primer tramo o corredor boliviano, de actividad antropogénica en camellones y terraplenes (Mapa II).}

Una vez dejadas las localidades ribereñas brasileras del estado de Rondonia, remontando el río Madeira, o las localidades ribereñas del río Itenez/Guaporé, cuyas cabeceras se conectan con el Alto Río Paraguay a través de la Chapada dos Parecis, se alcanza la Bolivia amazónica, frontera que se destaca por sus ríos de llanura (Mamoré, Beni, Acre, y Madre de Dios), donde cada localidad se caracteriza por su altura promedio sobre el nivel del mar (de ahora en más msnm). También se destacan por su particular litología de suelos arcillosos y limosos, la terra preta o tierra negra (o de ácidos orgánicos) en el río Blanco, afluente del río Itenéz/Guaporé, territorio de los indios Baures (de lengua arawak), ${ }^{4} \mathrm{y}$ los canales y campos elevados (para preservarse de las inundaciones) o cultura de la sabana tropical inundable, y los montículos habitacionales o lomas de tierra en los Llanos de Moxos, conocida como la cultura hidráulica de las lomas.

\footnotetext{
${ }^{4}$ ver Erickson, 2000; y Erickson, Alvarez, y Calla, 2008. Para la tierra negra del altiplano boliviano, ver Apffel-Marglin, 2013.
} 
Artigo original

Hegemonia - Revista Eletrônica de Relações Internacionais do Centro Universitário Unieuro

ISSN: $1809-1261$

UNIEURO, Brasília, número Especial, 2016, pp. 121-174.

Se estima existieron unas veinte mil lomas artificiales de una extensión promedio de veinte hectáreas cada una, lo que supone una superficie total de medio millón de hectáreas. Estas lomas en parte estaban unidas entre sí por camellones y terraplenes de entre 15 y 30 kilómetros de longitud, sobre los que se podía caminar y a cuyos lados hay canales en los que podían navegar canoas transportando materiales. ${ }^{5}$ Eriksen (2011) emparenta estas estructuras agrarias con la cultura Tiwanaku de hace veinte siglos, ${ }^{6}$ parentesco que se vuelve verosímil por cuanto se han encontrado urnas funerarias, es decir cementerios pre-históricos, ${ }^{7}$ vasijas de cerámica, hachas, figurines, fogones y hornos que se remontan a esos tiempos. ${ }^{8}$

También se destaca este primer tramo por el mesianismo y el milenarismo peregrinatorio de los grupos étnicos tupí-guaraní en busca de la Tierra $\sin$ Mal y la Loma Santa, protectora del flagelo inundatorio, ${ }^{9}$ por la difusión de la propiedad de la tierra entre la elite indígena Beniana; ${ }^{10}$ por la inmigración cosmopolita que en el siglo $X X$ incluyó colonos japoneses; ${ }^{11}$ y menonitas o pietistas rusos de habla plautdietsch

\footnotetext{
${ }^{5}$ ver Mann, 2008.

${ }^{6}$ ver Eriksen, $2011,75,78$ y 80.

7 ver Eriksen, 2011, 81.

${ }^{8}$ ver Durán Coirolo y Bracco Boksar, 2000.

${ }^{9}$ Riester y Fischermann, 1976.

10 ver Guiteras Mombiola, 2010.

${ }^{11}$ Siemann, 2012; Suzuki, 2010.
} 
Artigo original

Hegemonia - Revista Eletrônica de Relações Internacionais do Centro Universitário Unieuro

ISSN: $1809-1261$

UNIEURO, Brasília, número Especial, 2016, pp. 121-174.

o bajo alemán; ${ }^{12}$ y por numerosos viajes de exploración practicados en el siglo XIX.13 También se da cita en esta región la etnía arawak, cuyo idioma en sus cuatro variantes (ignaciano, javeriano, loretano y trinitario) los jesuitas quisieron imponer como lengua franca pero que fracasaron quedando esta región como una de las más lingüisticamente prolíficas. ${ }^{14}$ Y su milenarismo peregrinatorio se habría volcado a aquellos santuarios ilustrados por petroglifos o pictogramas, tales como los sarcófagos de Chachapoyas; y los frescos o petroglifos de Las Juntas, provincia de Bagua; Balsapuerto, Loreto; Quillabamba, Provincia de La Convención, Cuzco; y Pusharo y Paucartambo, departamento de Madre de Dios en Perú, o el de Chiribiquete en la cuenca del Caquetá, Colombia. ${ }^{15}$

En la larga ruta fluvial del Guaporé/Iténez, que arranca en la localidad matogrossense de Pontes y Lacerda, y luego alcanza varios destinos diferentes a distintas alturas sobre el nivel del mar, alcanzándose primero la desembocadura de ríos de llanura boscosa, paralelos entre sí y cuasiperpendiculares, que de este a oeste son los ríos Baures, Mamoré, Beni, y el Madre de Dios que desemboca en forma oblícua o en diagonal, con aguas procedentes de los Andes meridionales peruanos (de los ríosafluentes Caspajali y Manu), y en cuya desembocadura arborescente se

\footnotetext{
12 Hedberg, 2007.

13 ver Jetté y Suárez, et.al., 2003, 25.

14 Ver Rose, 2012. Para los caripunas y pacaraguas de la amazonia boliviana, ver Córdoba, 2014.

${ }^{15}$ Eriksen, 2011, 46, ftnt. 60.
} 
Artigo original

Hegemonia - Revista Eletrônica de Relações Internacionais do Centro Universitário Unieuro

ISSN: $1809-1261$

UNIEURO, Brasília, número Especial, 2016, pp. 121-174.

encuentra con el río Beni, el cual al unirse con el Mamoré da lugar al río Madeira. ${ }^{16}$

La cuenca del río Mamoré se extiende a lo largo de $1.300 \mathrm{~km}$. (cuyo cauce divaga o muda unos seis $\mathrm{km}$ y tiene por ende dos o tres ubicaciones distintas, entre ellas Puerto Ganadero y Puerto Almacén luego Puerto Ballivián), departamento del Beni, desemboca en el río Iténez/Guaporé, y llega a la ciudad de Guayamirím o Guayaramerín (128 metros sobre el nivel del mar, de ahora en más msnm; 39.000 habitantes, de ahora en más h.; y 4,12 metros de profundidad o calado), antiguo Puerto Palmira, fundada por los pioneros bolivianos del caucho, en la que hay una base naval con sucursal en Puerto Villarroel, y una Casa de la Cultura donde se encuentra el Archivo de la afamada Casa Suárez. ${ }^{17}$

Dicha ciudad está situada frente a la ciudad gemela de Guajara Mirim, en el estado de Rondonia, con la cual mantiene una suerte de área de libre comercio. ${ }^{18} \mathrm{El}$ Mamoré recoge como afluente al río Ytenéz/Guaporé, y más arriba en la confluencia de los ríos Yacuma y Mamoré se llega a las Pampas del Yacuma (un verdadero humedal) y a la localidad de Santa Ana del Yacuma (123 a 194 msnm, fue de 10,26 metros y hoy tiene una lectura de 0,60 metros de calado, 24.680 h.), donde persiste la etnía y la lengua movima, y donde el ingeniero boliviano Agustín Palacios, inspirado en el botánico checo Tadeo Haenke, pensó construir en 1850 un canal

\footnotetext{
16 En la desembocadura con el río Beni, se pueden ver arenas que se mueven cíclicamente por efecto de la curva de remanso que se presenta por diferentes condiciones hidrológicas de ambos ríos

17 ver Perea Borda, 1998, 124; y Jetté y Suárez, et.al., 2003, 30, nota 10.

18 Gemaque Souza, 2014, 74.
} 
Artigo original

Hegemonia - Revista Eletrônica de Relações Internacionais do Centro Universitário Unieuro

ISSN : $1809-1261$

UNIEURO, Brasília, número Especial, 2016, pp. 121-174.

hasta el Lago Rogagua, que produzca la interconexión del Rio Yacuma con el río Negro, afluente del Beni. ${ }^{19}$ Más arriba, a orillas del río Ichilo, también afluente del Mamoré, se llega en la región del Alto Mamoré en ocho (8) días de navegar en lancha al Puerto Trinidad, ex Misión jesuítica de la Santísima Trinidad, fundada en 1687, capital del Beni (160 msnm y 110.000 h.), y luego a Puerto Ballivián (155 msnm), y más arriba aún al Puerto Villarroel (180 msnm, 2,72 metros de profundidad, y 1.778 h.) y a Villa Tunari (298 msnm y 3213 h.), donde desembocan primero el río Chapare, y más arriba el río Grande, en cuyas orillas se encuentra la ciudad capital de Santa Cruz de la Sierra. Lo cual suma en la totalidad del Mamoré $65.458 \mathrm{~h}$.

En la cuenca del río Beni, o río que corre (de 1053 km de largo y solo 890 $\mathrm{km}$ navegables que toman dos semanas recorrerlos), conocida como Llanos de Moxos o llanura Beniana (de suelos aluviales de origen cuaternario, con un humedal transitorio tres meses al año), y también en el departamento de Pando, se llega primero en la margen izquierda del río Beni a la desembocadura de muchos ríos en forma arborescente, entre ellos el río Orthon. Remontando este último, en su nacimiento se da la confluencia de los ríos Tahuamanu y Manuripi, que a su vez nacen en la región peruana de Madre de Dios. Luego, más arriba por el río Beni se llega a su confluencia con el río Bajo Madre de Dios (o Amarumayo o río de las serpientes, de $1150 \mathrm{~km}$ de largo, de los cuales $665 \mathrm{~km}$ transcurren en Perú), y en ella se encuentra la localidad de Riberalta (130 msnm, 2,

\footnotetext{
19 Perea Borda, 1998, 230; y Eriksen, 2011, 77. Para los humedales de Bolivia, ver Beck, Sarmiento, Paniagua Z., Miranda \& Ribera, 2000.
} 
Artigo original

Hegemonia - Revista Eletrônica de Relações Internacionais do Centro Universitário Unieuro

ISSN: $1809-1261$

UNIEURO, Brasília, número Especial, 2016, pp. 121-174.

20 metros de calado, y 95.000 h., fundada por el pionero Antonio Baca Díaz), sumando en el río Beni una totalidad de 100.000 h.. ${ }^{20}$

Y remontando el Bajo Madre de Dios, desde Guayaramerín, por su margen derecha, a $72 \mathrm{~km}$ de haber dejado la confluencia con el río Beni, se da con las poblaciones indígenas piros y takanas, y con muchos poblados permanentes que fueron viejas barracas caucheras y donde hoy se produce almendra (en Brasil se la denomina castaña) con mano de obra femenina (quebradoras, descascadoras), entre ellas los poblados de Miraflores y La Conquista, y más arriba con los ríos-afluentes Colorado y Heath, y en sus orillas con el Puerto Heath y la Reserva Nacional ManupiriHeath, y más arriba entramos en territorio peruano, donde tropezamos con el Medio Madre de Dios y luego navegando río arriba, a razón de 8 km cada hora, que insumen 4 días de navegación, damos con Puerto Maldonado, cuya distancia con el Guajará-Mirim alcanza los 957 km.

Y retomando el río Beni se alcanza 370 km más arriba la región del Alto Beni, donde por su margen izquierda se llega a la desembocadura de los ríos Tuichi, Quendeque y Madidi, donde se encuentra el Parque Nacional del Alto Madidi (entre 5700 y 180 msnm), asiento de los ocultos indios toromonas (en cuya investigación exploratoria desapareció recientemente el biólogo noruego Lars Hafskjold), y donde también se ha programado un istmo-atajo con el río Heath, proyecto que había sido ideado por Tadeo Hanke en $1799 .{ }^{21}$ Luego retomando de nuevo el río Beni se alcanza aguas

\footnotetext{
20 Perea Borda, 1998, 127. Para la cultura reduccional-jesuítica de los Llanos de Mojos, ver Block, 1997; y Querejazu Lewis, 1991.

${ }^{21}$ Perea Borda, 1998, 129.
} 
Artigo original

Hegemonia - Revista Eletrônica de Relações Internacionais do Centro Universitário Unieuro

ISSN: $1809-1261$

UNIEURO, Brasília, número Especial, 2016, pp. 121-174.

más arriba y en su margen derecha con el río Negro, que conecta con el Lago Rogagua; 22 y más arriba con la confluencia de los ríos Kaka y Alto Beni (que da origen al río Beni), donde se encuentra la localidad de Puerto Linares. Terminada la Ilanura, en el Alto Beni, se llega a la localidad de Rurrenabaque (229 msnm y 8460 h.), donde como culto a la virilidad una población rural muy mestizada celebra torneos con jocheo de toros (también se celebra en San Ignacio de Mojos y en Puerto Trinidad), y más arriba aún se llega a su naciente la montaña de Chacaltaya. ${ }^{23}$

Más al oeste del Beni, bajan primero el río Abuná y luego el Acre, este último afluente del Purús, río que va por Brasil hasta el Amazonas. Subiendo el Abuná se llega a la población de Puerto Rico (320 msnm y 4.494 h.); y subiendo Acre, se llega al afluente Río Yaco, y al puerto de Cobija (235 msnm y 42.200 h.), capital del departamento de Pando (antiguo territorio de Moxos y hoy conocido como amazonía pandina, de selva alta, más geológicamente elevada que el Beni). Más arriba y siempre a orillas del río Acre, en el punto tripartito o triple frontera BrasilPerú-Bolivia se hallan las localidades de Assís (239 msnm y 5351 h.), Iñapari (230 msnm), y San Pedro de Bolpebra (278 msnm y 400 h.), productoras de frutos naturales como la moringa (árbol proteico), el asaí (palmera nativa), el majo (palmera que da leche), el pejibaye (fruto amarillo rojizo que se da en racimos en una palmera de tronco espinoso, recolectado por los indios yuracaraes y que fue domesticado hace miles

\footnotetext{
22 Está pensado construir una interconexión fluvial entre los ríos Mamoré y Beni atravesando los ríos Yacuma y Negro (Perea Borda, 1998, 230)

${ }^{23}$ Ver Perea Borda, 1998, 125.
} 
Artigo original

Hegemonia - Revista Eletrônica de Relações Internacionais do Centro Universitário Unieuro

ISSN: $1809-1261$

UNIEURO, Brasília, número Especial, 2016, pp. 121-174.

de años conjuntamente con la yuca o mandioca), y el copoazú (fruta con propiedades cosméticas y nutricionales). ${ }^{24}$

Finalmente, para el entero del primer tramo se alcanza una totalidad de 165.000 h. Mientras la población de la ribera del río Mamoré es de 65.458 habitantes, y la del río Beni de 100.000 h. (funcionó como vínculo entre las tierras altas del Lago Titicaca y las bajas de los Moxos), en el departamento del Beni (Bolivia); ${ }^{25}$ sin tomar en cuenta su ciudad capital Puerto Trinidad (160 msnm y 130.000 h.), el total es menos del doble, de $300.000 \mathrm{~h}$. Esta diferencia obedecería a que no se computaron los numerosos grupos étnico-lingüísticos takanas (takana había sido el indio arquero Bruno Racua clave en la recuperación para Bolivia de la ciudad de Cobija en la Guerra Acreana), ${ }^{26}$ yuracarés; ${ }^{27}$ yukis (tupi-guaraní); ${ }^{28}$ baures (arawacos localizados en el río Blanco, afluente del Itenez, y procedentes de Moxos); iténez (localizados en el río Guaporé); chimanes; lecos (canoeros y remeros especializados en transporte fluvial); mosetenes; ${ }^{29}$ moxeños ignacianos, loretanos, javerianos y trinitarios (arawak, responsables de la introducción de trompetas de madera (corteza de abedul) que algunos como Izikowitz la atribuyen a la etnía

\footnotetext{
24 Ver Paredes Pando, 2013, 249-256.

${ }^{25}$ ver Eriksen, 2011, 78.

${ }^{26}$ ver Ponz Sejas, 2005.

27 ver Nordenskiöld, 2003; persiguen la Tierra sin Mal, y consideran al fruto conocido como pejibay como su madre, porque durante los meses de febrero a marzo con el pejibay "tenían la vida".

${ }^{28}$ ver Querejazu Lewis, 1991.

${ }^{29}$ ver Gómez-García Krust, 2010.
} 
Artigo original

Hegemonia - Revista Eletrônica de Relações Internacionais do Centro Universitário Unieuro

ISSN : $1809-1261$

UNIEURO, Brasília, número Especial, 2016, pp. 121-174.

Uru; ${ }^{30}$ chamas, pacawaras; ${ }^{31}$ araonas (exógamos entrelazados con los kavineños, muy vinculados a los franciscanos); ${ }^{32}$ kavineños de lengua takana (exógamos, vinculados a los araonas, localizados cerca del río Beni); reyesanos o maropas (región de Reyes y Santa Rosa, en la provincia Ballivián, departamento del Beni); chácobos (departamento del Beni); sirionós o mbía (sur del Beni); 33 cayubabas (El Beni); e itonamas (El Beni), procedentes de distintas familias lingüísticas, entre ellas la lengua chapakura, que también hablan los Wari en Brasil. ${ }^{34}$

Cabe destacar, que en la comunidad takana, se registra la presencia de asociaciones y comunidades excepcionalmente productivas. Entre ellas se han hecho conocer la Asociación de Artesanos Tacanas del Madidi y la Comunidad de Santa Rosa de Maravilla (provincia Ballivián, departamento del Beni).

\section{A-II.- Segundo tramo o corredor peruano-ecuatoriano, de selva alta, endogámico y monolingüe (Mapa III)}

Dejando las localidades bolivianas y remontando el río Madre de Dios, se alcanzaría el segundo tramo del circuito amazónico-platino, el corredor

${ }^{30}$ ver Eriksen, 2011, 80.

31 ver Villar, Córdova, y Combés, 2013.

32 para el idioma araona, ver Emkow, 2012.

33 ver Nordenskiöld, 2003.

${ }^{34}$ Conklin, 2005, 47. Para los panos bolivianos en el imaginario cauchero, ver Córdoba, 2014. 
Artigo original

Hegemonia - Revista Eletrônica de Relações Internacionais do Centro

Universitário Unieuro

ISSN: $1809-1261$

UNIEURO, Brasília, número Especial, 2016, pp. 121-174.

amazónico peruano, donde cada localidad se caracteriza por su altura promedio sobre el nivel del mar (de ahora en más msnm).

En la frontera peruana con Bolivia y Brasil, departamento Madre de Dios, la localidad potencialmente más rica, territorio que fue el espacio frecuentado por Fitzcarraldo, y hoy por el narcotráfico, se alcanza en la confluencia del turbulento río Tambopata con los ríos Alto Madre de Dios y las Piedras, la localidad de Puerto Maldonado (139 msnm, 210.524 h., dista de Pucallpa $1894 \mathrm{Km}$ ), en cuya área de influencia viene depredando el eco-sistema la minería de oro a cielo abierto (con el método de la chupadera), impulsada desde el London Bullion Market y sus compañías filiales (Ohio Precious Metals, Dubai Multicommodities Centre, Engelhard Corporation, etc.). ${ }^{35}$ Esta minería que ha depredado miles y miles de hectáreas consiste según García-Morcillo (1982) "...en talar el bosque y cavar hasta llegar al cascajo [existente debajo del manto arcilloso amazónico], que se lava,..., de uno a dos metros cúbicos de grava para obtener [por lixiviación o amalgama de cianuro] un gramo de oro". ${ }^{36}$

Entre Puerto Maldonado y el río Heath, la profundidad del canal fluctúa entre $4 \mathrm{~m}$ y $12 \mathrm{~m}$; entre la boca del río Inambarí y Puerto Maldonado el canal de navegación tiene profundidades que fluctúan entre $2.5 \mathrm{~m}$. y 5.0 m.; y en algunos tramos la distancia alcanza hasta $18 \mathrm{~m}$. Más arriba, en la cuenca del Alto Madre de Dios, se debería construir un canal a través

\footnotetext{
35 Perea Borda, 1998, 127. El río Colorado desagua por la margen derecha en el río Madre de Dios, que tiene por afluente al río Puquiri, de una longitud aproximada de 80 $\mathrm{km}$., y este tiene por afluente al río Huepetuhe, donde actualmente se recolecta oro a un tremendo costo ecológico, ver Castilla C., Luna Amancio y Torres López, 2015.

${ }^{36}$ Ver García-Morcillo, 1982.
} 
Artigo original

Hegemonia - Revista Eletrônica de Relações Internacionais do Centro Universitário Unieuro

ISSN: $1809-1261$

UNIEURO, Brasília, número Especial, 2016, pp. 121-174.

de un istmo de once kilómetros que inaugure la interconección del río Caspajali afluente del Manu, a su vez afluente del Alto Madre de Dios con el río Serjali, afluente del Mishagua-a su vez afluente del Urubamba, que lleva a Puerto Atalaya. ${ }^{37}$ Este último dista hacia el sur, hasta Puerto Maldonado, un trayecto de 1.349 km.; y hacia el norte, hasta Pucallpa, otros $650 \mathrm{~km}$. , combinando vías terrestres con las fluviales.

En cuanto a diferencias estadísticas, en la cuenca de Madre de Dios, estas fueron muy marcadas, pues su población indígena está compuesta por más de medio centenar de grupos étnicos que pertenecían a una docena de familias lingüísticas. Mientras en la confluencia del Alto Madre de Dios y el río Tambopata la población es de 210.524 h., la del departamento de Madre de Dios es inferior en casi la mitad, un total de 109.555 habitantes. Esta diferencia en menos obedecería a que no habrían sido computados los grupos étnico-lingüísticos de las familias harákmbet (arasaeri, kishambaeri, pukirieri, sapiteri, toyoeri, wachipaeri, amarakaeri), y arawak (piros o yines y machiguengas), ${ }^{38}$ localizados a orillas del río Urubamba, de 8.679 h.. ${ }^{39}$

Este tramo o corredor peruano prosigue con el río Urubamba y se continúa con el Ucayali, y fue tenido --antes y después de la conquista-- como el vínculo clave para el transporte de mercancías (coca, algodón, plumas,

\footnotetext{
${ }^{37}$ A la vera de los ríos Mishagua y Serjali, en el asentamiento de Santa Rosa de Serjali, vive la reserva de los indios Nahuas, recientemente contaminados con mercurio.

38 ver Sánchez Vásquez, 2010.

${ }^{39}$ para el vínculo genético entre los Harakmbut y los Katukina, los mismos que recrearon la Asociación Katukina de Campinas-AKAC, del Alto Juruá, ver Gray, 1996; y Adelaar, 2000.
} 
Artigo original

Hegemonia - Revista Eletrônica de Relações Internacionais do Centro Universitário Unieuro

ISSN: $1809-1261$

UNIEURO, Brasília, número Especial, 2016, pp. 121-174.

resina, cera, madera y tintes o colorantes) entre las tierras altas de los Andes (Cuzco) y las tierras bajas, donde la ruta para el norte se hacía bajando por la acentuada pendiente fluvial del Ucayali, y para el sur conectando vía terrestre se baja por los ríos Caspajali, Manu y Madre de Dios, en dirección a Puerto Maldonado, al río Beni y a su cuenca receptora el río Madeira. ${ }^{40}$

La región fue ocupada por poblaciones de habla arawak y también por grupos pano incluídos los shipibo y los konibo. ${ }^{41}$ Su hidrografía se caracteriza por la combinación de tres (3) grandes afluentes sucesivos, de ríos de montaña de pronunciada pendiente procedentes de las laderas orientales de los Andes (de 300 a mil msnm), donde prevalecen territorios de selva alta de intensa pluviosidad (de tres mil a seis mil mm. anuales), y también de ríos de llanura y selva baja, alineados de sur a norte, donde el margen o vertiente izquierdo es occidental y el derecho oriental, que son el Tambo/Apurimac, el Marañón/Huallaga, y el Napo. Al bajar del macizo andino, dichos ríos y sus afluentes en forma dendrítica o arborescente (son ríos más cortos, rectos y veloces) vienen cortando los relieves cordilleranos a través de pongos (cañones o gargantas), que son los que separan a cada uno de ellos. ${ }^{42}$ Es en estos pongos donde se han encontrado inscriptos extensos petroglifos como el de Pusharo, en Madre de Dios. Los shipibo y los konibo (de habla pano, de cerámica con diseños laberínticos, y residentes a lo largo de los ríos Aguaytía y Pachitea,

\footnotetext{
40 Eriksen, 2011, 46. Para los contactos españoles y el cambio social en el río Ucayali, ver Myers, 1974.

${ }^{41}$ Eriksen, 2011, 41-42.

42 para la etnogeografía y dinamica de "frontera": y las nuevas territorialidades indígenas de los pueblos Arawak de la amazonia occidental, ver Deus, 2009.
} 
Artigo original

Hegemonia - Revista Eletrônica de Relações Internacionais do Centro Universitário Unieuro

ISSN: $1809-1261$

UNIEURO, Brasília, número Especial, 2016, pp. 121-174.

afluentes del Ucayali, donde en el período de creciente el Pachitea puede ser navegado por embarcaciones a vapor de hasta cuatro pies de calado) controlaban el Ucayali medio comerciando río arriba hacia el sur con los piro o yines (arawak), y hacia el norte río abajo con las tribus de habla tupí, los cocama, cocamilla y omaguas. ${ }^{43}$ Fueron los shipibo y los konibo conjuntamente con los ashaninka y los amuesha (o yanesha, de la familia lingüística arawak) la base social de la rebelión mesiánica del cusqueño Juan Santos Atahualpa (1742-56), es decir, las poblaciones que habitaban el Gran Pajonal, territorio de las Misiones Franciscanas, en las cuencas de los ríos Tambo y Perené.

En la cuenca del Urubamba, que nace en el nudo de Vilcanota (4.314 msnm), verdadera fuente originaria del río Amazonas, tienen sus orígenes la nación Piro (grandes remeros, navegantes, políglotas, y conocedores de una astronomía ancestral), cuya lengua es de la familia arawak (que comerciaban loros, algodón, canoas, goma, resinas, y aceite de tortuga); ${ }^{44}$ y que en la rebelión de Juan Santos Atahualpa (1742) oficiaron de guías y colaboradores, y durante la fiebre cauchera pasaron a residir en el río Alto Purús. ${ }^{45}$ Al descender por el río Urubamba se da el encuentro con el santuario nacional Megantoni (provincia de La Convención en el departamento de Cusco) y con el Parque Nacional Otishi (500 msnm), y con el primer afluente de este tramo o corredor peruano, el río Tambo, donde la diferencia entre la creciente máxima y mínima alcanza un rango

\footnotetext{
43 Eriksen, 2011, 46. Para la ambigüedad epistemológica y moral en el cosmos social de los yine o piros, ver Opas, 2012.

${ }^{44}$ ver Eriksen, 2011, 47.

${ }^{45}$ ver Gow, 2006; Ramírez Ponce, 2008.
} 
Artigo original

Hegemonia - Revista Eletrônica de Relações Internacionais do Centro Universitário Unieuro

ISSN : $1809-1261$

UNIEURO, Brasília, número Especial, 2016, pp. 121-174.

de $12 \mathrm{~m}$.. Pero al remontar el Tambo, y luego el río Ene se llega al río Apurimac, que más arriba recoge las aguas del río Mántaro (antes conocido como río Jauja). Más abajo por el Urubamba se confronta con Puerto Ocopa (390 msnm y 2159 h.) y con Sepahua (276 msnm), y en la confluencia del río Ene y el Perené tiene lugar Puerto Pardo, y más abajo en la confluencia del Urubamba con el Tambo, tiene nacimiento formal el río Ucayali y se alcanza Puerto Atalaya (220 msnm, con embarcaciones de hasta doce [12] pies de calado, y 10.243 h. que dista de Puerto Maldonado 1.349 km.), capital del distrito Alto Ucayali, y bajando 66 msnm por el Ucayali damos con la ciudad de Pucallpa (154 msnm, entre la creciente máxima y mínima un rango de 9.3 m., y 204.772 h.), capital del departamento de Ucayali, reino de los mototaxis, y sede en la Laguna de Yarinacocha del Instituto Lingüístico de Verano (ILV), fundado por Guillermo Townsend en 1945.46 En su puerto compuesto de cinco pontones flotantes de acero conectados a tierra con dos puentes basculantes atracan simultáneamente nueve barcos. ${ }^{47}$

En materia de duración y distancias fluviales, desde Pucallpa (Puerto La Hoyada, a 2,5 Km. de la ciudad), hasta Iquitos, vía el río Ucayali, con paradas en los puertos de Requena y Contamana, el viaje en deslizador demora 1 o 2 días, a razón de $33 \mathrm{~km}$. por hora o 4 veces la velocidad en vapor, dependiendo del nivel del río; y en lancha o "motonave" demora 4 o 5 días, a razón de $8 \mathrm{~km}$. por hora, dependiendo de la corriente del río.

\footnotetext{
${ }^{46}$ sobre el Instituto Lingüístico de Verano (ILV), ver Drumond Mendes Barros, 2004.

47 Aguas arriba de Pucallpa se forman bancos de arena que dan lugar a la isla Angamos (Perea Borda, 1998, 162).
} 
Artigo original

Hegemonia - Revista Eletrônica de Relações Internacionais do Centro Universitário Unieuro

ISSN: $1809-1261$

UNIEURO, Brasília, número Especial, 2016, pp. 121-174.

Bajando aún más por el Ucayali (posee un calado mayor a 2.10 m., que comienza a capturar ríos de menor caudal como el río Aguaytía asiento de la etnía shipibo), tropezamos por izquierda con el puerto de Requena (153 msnm y 20.000 h.), distrito de Alto Tapiche, y con la boca del segundo gran afluente, el río Marañón o Tungurahua así denominado por los indígenas. Este río nace en el nevado de Yarupa, entre las cordilleras occidental y central, donde tuvo su sede originaria la cultura Chavín de Huántar que fue bisagra con el mundo amazónico, tal como el arqueólogo peruano Julio Tello lo probó mediante la iconografía zoomórfica (monos, jaguares y serpientes). El Marañón atraviesa luego dos cordilleras cortando camino por varios pongos muy difíciles de navegar.

En la confluencia del Ucayali con el Marañón damos con el pueblo de Nauta (111 msnm, a $3800 \mathrm{~km}$ del océano Atlántico, y 28.681 h.) y con los Shipibo-Konibo de la familia lingüística Pano (enemigos de los Piro). ${ }^{48}$ En esta región se registra la provincia de Requena (153 msnm y 65.692 hab.), departamento de Loreto, que comprende once (11) distritos que son Alto Tapiche, Capelo, Emilio San Martín, Maquía (habita una etnia tupi-guaraní), Puinahua, Saquena, Soplin, Tapiche, Jenaro Herrera, y Yaquerana (habita una etnia pano grupo mayoruna o matzés).

Remontando ahora el Marañón damos en la margen izquierda primero con el río Tigre (a $240 \mathrm{~km}$ de Iquitos, donde desaguan las aguas del río Corrientes), y con el puerto de Saramiriza (145 msnm y 2.000 h.), sumando en toda la cuenca del Marañón y el Ucayali 235.453 h.. Entre los ríos Tigre y Pastaza (Laguna de Chirapa), a orillas del río Chambira

\footnotetext{
${ }^{48}$ para la vida e historia de los Shipibo-Konibo, ver Tournon, 2002.
} 
Artigo original

Hegemonia - Revista Eletrônica de Relações Internacionais do Centro Universitário Unieuro

ISSN: $1809-1261$

UNIEURO, Brasília, número Especial, 2016, pp. 121-174.

(provincia de Loreto, departamento de Loreto), se registra la presencia del grupo étnico Urarina, célebre por las formas locales de su práctica chamánica. El grupo étnico Urarina es también conocido por el equilibrio de poder que practica con las etnías vecinas jívaras y tupís, y por su particular convencimiento de que no sólo la gente produce gente en el trato con terceros, sino que también experimenta sus propias acciones en forma personal. ${ }^{49}$ Por otro lado, la identidad lingüística urarina se caracteriza por sus dialectos diferenciados en materia fonológica, sintáctica y léxica. La lengua urarina es vecina a otras lenguas como el candoshi, shapra o murato (de la familia jíbara), 50 el cocama (de la familia tupí), el yameo (de familia peba-yagua), ${ }^{51}$ y el cuasi-extinto jébero (cuyos pobladores canjeaban personas cautivas con los españoles de Moyobamba a cambio de herramientas de hierro que a su vez las comercializaban con los indios cocama por canoas o piraguas. ${ }^{52}$

Más arriba, en la margen izquierda del Marañón damos sucesivamente con la boca del río Pastaza (ríos de aguas blancas o limosas, donde desagua el río Bobonaza, el mismo que recorriera río abajo el antropólogo francés Philippe Descolá en su investigación de los indios Achuar), más arriba se comunica con el Lago Rimachi (al que fluyen los ríos Capuri y Rimache, que a su vez alimentan al río Pastaza, pertenece a la Comunidad Nativa de Cadoshi), y luego con la de los ríos Morona (a 680 km de Iquitos) y Santiago (sus aguas traen oro y últimamente se han visto

\footnotetext{
49 Walker, 2014.

50 Para el destino, muerte y regeneración entre los Candoshi, ver Surrallés, 2013.

51 ver Morales Chocano, 2004; y Walker, 2009.

52 Eriksen, 2011, 44.
} 
Artigo original

Hegemonia - Revista Eletrônica de Relações Internacionais do Centro Universitário Unieuro

ISSN: $1809-1261$

UNIEURO, Brasília, número Especial, 2016, pp. 121-174.

navegar deslizadores), que bajan de los Andes ecuatorianos. ${ }^{53}$ En esta región se registra la provincia de Datem del Marañon (49.571 h.), departamento de Loreto, con capital en San Lorenzo (133 msnm y 6.532 h.), y donde se encuentra la Escuela de Acuicultura de la Universidad Nacional de la Amazonía Peruana (UNAP). Esta provincia comprende seis (6) distritos, que son Barranca (554 h.); Manseriche (con población de la etnia aguaruna o awajun, cultora en el pasado de la práctica jíbara de reducir cabezas, y hoy vecina de ricos yacimientos petrolíferos, donde a partir del pongo de Manseriche río abajo el río Marañón se vuelve navegable), Morona (habita la etnia cahuapana grupo que incluye las lenguas chayahuita y jébero, a orillas del Paranapura con 13.700 h.), Pastaza (donde habita en forma impuesta la etnia quechua, grupo quechua del río Pastaza), y Andoas (con capital en el pueblo de Alianza Cristiana (156 msnm y 471 h.), Nuevo Andoas (624 h.), Vista Alegre y Sauki, de los pueblos achuar, kichwa, wampes y sharpa.

Luego damos en la margen derecha del Marañón con la boca del río Huallaga (nace entre las cordilleras central y oriental, en el departamento de Loreto). El río Huallaga fue la ruta necesaria del tráfico de mercancías de la selva alta del Ecuador o de la red de intercambio mindalá, desde donde se traía sal y veneno para cerbatanas (curare y barbasco) a cambio de pescado, cera, mandioca, coca y sombreros de plumas que venían del Putumayo y el Caquetá. ${ }^{54}$ La red de intercambio mindalá era

\footnotetext{
53 Para las rutas del oro ilegal en la amazonía, ver Valencia, 2015.

54 Eriksen, 2011, 43. El barbasco es un bejuco que machacado y mezclado con ceniza sirve para envenenar a los peces sin peligro alguno para su consumo (Dominguez, 1987).
} 
Artigo original

Hegemonia - Revista Eletrônica de Relações Internacionais do Centro Universitário Unieuro

ISSN: $1809-1261$

UNIEURO, Brasília, número Especial, 2016, pp. 121-174.

protagonizada antiguamente por una elite de comerciantes de habla barbacoa (etnías cara y yumbo) que comerciaban oro, conchas de hueso, algodón, pescado, sal, pimienta, y coca. ${ }^{55}$ Mientras la población de la ribera de los ríos Marañón y Ucayali es de 235.453 h., la población en el departamento del Ucayali es de 205.000 h.. Sin contar su capital Pucallpa, la población es mayor en apenas unos $30.000 \mathrm{~h}$. Esta diferencia tiene su explicación pues el departamento comprende también las poblaciones de Puerto Atalaya (10.000 h.), y Contamana (134 msnm y 17.000 h.), y grupos étnicos como los Kulina (865 h.), Sharanaguas, Shaninahuas, Mastanahuas (79 h.), Marinahuas, y Amahuacas, a orillas del Alto Purús (Perú) y sus afluentes del margen izquierdo, los ríos Cújar, Curiuja y Curanja (explorados por Chandless). ${ }^{56}$

Remontando ahora el río Huallaga (de $1350 \mathrm{~km}$ de longitud), navegable solo en balsas y en canoas con motor fuera de borda o peque peque, y también últimamente en deslizadores, primero en la confluencia de los ríos Huallaga y Paranapura Ilegamos a Yurimaguas (de 148 a 179 msnm, $12 \mathrm{~m}$. de calado al pie del muelle, y 45.348 h., situada en el límite de la navegación del Huallaga), que cuenta con un embarcadero flotante compuesto con pontones de acero, conectados a tierra con unos puentes basculantes. En materia de distancias fluviales, desde Yurimaguas bajando hasta Iquitos, que son 388 km., vía los ríos Huallaga y Marañón, con una parada en el puerto de Nauta, demora en deslizador, de 12 a 15

\footnotetext{
55 Eriksen, 2011, 43.

56 para reflexionar sobre los grupos amazónicos del Perú desde una perspectiva de ecología humana, ver Follér, 1999; para la vigencia de lo ancestral en la Amazonía peruana, ver Mouriès, 2014. Para los Kulinas transformados en Marubos, ver Fleck, 2007.
} 
Artigo original

Hegemonia - Revista Eletrônica de Relações Internacionais do Centro Universitário Unieuro

ISSN: $1809-1261$

UNIEURO, Brasília, número Especial, 2016, pp. 121-174.

horas $040 \mathrm{~km}$. por hora, dependiendo del caballaje del motor; y en lancha o "motonave" de 3 a 4 días a razón de $100 \mathrm{~km}$. cada día, o 4 km. por hora, dependiendo del nivel de los ríos. Yurimaguas era tenida por la Perla del Huallaga, fundada en 1710 por la fusión de los indios Yuris con los Omaguas, donde luego tuvieron su asiento los amuesha o yanesha, de la familia lingüística arawak y de una cosmogonía animista que creía que los animales fueron antiguamente seres humanos. ${ }^{57}$ En la confluencia de los rios Caynarachi (afluente del Huallaga) y Yanayaku, llegamos a Barranquita (168 msnm) y luego subiendo casi un centenar de metros a Quillacaca y Chazuta (260 msnm y 14 comunidades), donde desagua el río Mayo (territorio de los antiguos Chankas). ${ }^{58}$

Y siguiendo el río Huallaga hacia arriba damos primero con Picota (223 msnm y 7.941 h.), y luego con Bella Vista (249 msnm y 22.116 h.), capital de la provincia de Bella Vista; Juanjuí (283 msnm), cuna histórica del Gran Pajatén o ciudad perdida en la selva (legado arqueológico de la cultura Chachapoyas) a orillas del río Abiseo; ${ }^{59}$ y también Puerto Pizana (465 msnm, distrito de Pólvora, provincia de Tocache); Tocache (497 msnm y 23.611 h.), capital de la provincia de Tocache; y se llega luego a Tingo María (600 msnm y 50.000 h.), capital de la provincia Leoncio Prado, departamento de Huánuco, conocida como la «Puerta de la Amazonia» o la Ciudad de la Bella Durmiente (por una cadena montañosa que parece una mujer recostada), donde tiene su sede la Misión

\footnotetext{
57 Perea Borda, 1998, 153; y Santos Granero, 2009, 5

${ }^{58}$ para la mitología y ritual entre la gente yanesha o amuesha, ver Santos Granero, 2004.

59 ver Bonavía Berber, 1968; ante los rumores de que El Dorado se encontraba en las montañas del naciente, el conquistador Alonso de Alvarado funda en 1538 San Juan de la Frontera de los Chachapoyas.
} 
Artigo original

Hegemonia - Revista Eletrônica de Relações Internacionais do Centro Universitário Unieuro

ISSN: $1809-1261$

UNIEURO, Brasília, número Especial, 2016, pp. 121-174.

Evangélica de la Amazonia Peruana (MEAP). Huánuco es actualmente un centro hortícola (camote, frijol, apio, col, papa, yuca etc.) y frutícola de primer orden, produciendo palta, mango, plátanos, papayas, y naranjas. Y remontando ahora el río Shilcayo, afluente del Mayo, alcanzamos Santa Cruz de los Motilones de Tarapoto o Tarapoto (250 msnm y 108.142 h.), donde suman en toda la cuenca 153.490 h. Tarapoto, fundada en 1782, es sede de congresos internacionales sobre medicinas tradicionales convocados por una comunidad terapéutica para recuperar adictos a las drogas denominada Takiwasi, verdadera puerta de entrada al chamanismo amazónico o turismo ayahuasca. 60

En este caso del río Huallaga, afluente del Marañón, las diferencias estadísticas y demográficas de sus cuencas y sub-cuencas fueron también muy marcadas. Mientras la población residente en la ribera del río Huallaga es de 153.490 h., la población en el departamento de Loreto (Perú) descontando la de su capital Iquitos, es casi cuatro veces mayor, de un total de 540.732 h. Esta diferencia obedece a que no hemos computado las poblaciónes de las provincias de Maynas (550.031 h.) que incluye a la capital Iquitos y una gran población mestiza, a la provincia de Loreto (62.165 h.), que incluye los distritos de Parinari (donde habita una etnia Tupi-Guaraní con 324 h.); a Tigre con capital en Intuto, y a Trompeteros con capital en Villa Trompeteros (126 msnm). La provincia de Alto Amazonas (104.667 h.) del departamento de Loreto, incluye como su capital la ciudad de Yurimaguas, que concentra la mitad de la población

\footnotetext{
60 sobre chamanismo y ciencia en la Alta Amazonía Peruana, ver Labaté, 2009; para la etnobotánica de la Amazonía Peruana, ver Vega Orcacitas, 2001; y Couly, 2013; para el turismo ayahuasca en el Huallaga, ver Homan, 2011; y para el comercio de la cultura en la amazonia brasilera, ver Chaumeil, 2009.
} 
Artigo original

Hegemonia - Revista Eletrônica de Relações Internacionais do Centro Universitário Unieuro

ISSN: $1809-1261$

UNIEURO, Brasília, número Especial, 2016, pp. 121-174.

provincial, y otros seis poblados urbanos: Santa Cruz, Lagunas, Balsapuerto (con petroglifos y poblado con indios chayahuita, autodenominados shawi), Shucushyacu, Jéberos (comerciantes en canoas), y Pampa Hermosa (donde habita la comunidad achuar, en el río Corrientes), y 107 comunidades correspondientes a grupos étnicolingüísticos de las familias Pano (shipibos del Ucayali), Arawaco (piros, campas), Tucano (orejones de cosmología creacionista), y Cahuapana (cashivos), a orillas de los ríos Huallaga, Morona y Pastaza. ${ }^{61}$

Volviendo al Ucayali, y descendiendo aún más por el mismo se alcanza la ciudad de Iquitos (104 msnm, entre la creciente máxima y mínima un rango de 8 m., 370.962 h., y con calados proyectados para la Hidrovía Amazónica de seis [6] pies en los Malos Pasos y nueve [9] pies en el Acceso a Iquitos), a orillas del ahora río Amazonas, verdadera confluencia de los ríos Ucayali y Marañón. Más abajo, la provincia de Mariscal Ramón Castilla (54.829 h.) comprende cuatro (4) distritos, Ramón Castilla (habitan etnias del grupo conocido como tikuna oriental), Pebas (tiene medio centenar de comunidades), San Pablo, y Yavarí (habita la etnia tikuna). En materia de duración y distancias fluviales, desde la ciudad de Iquitos hacia el norte río abajo hasta Caballococha (Provincia de Mariscal Ramón Castilla) son 311 km. navegables en 2 días de lancha y medio día o 12 horas en deslizador. Pero hacia el sur río arriba, hasta Nauta (Provincia de Loreto) son $115 \mathrm{~km}$. , que demora 14 horas de lancha a razón de 7 km. cada hora; hasta Requena (Provincia de Requena) son 157 km., en 19 horas de lancha a razón de $8 \mathrm{~km}$. cada hora; hasta Contamana (Provincia de Ucayali) son $431 \mathrm{~km}$. en 3 días de lancha a razón

${ }^{61}$ para los cashivos, ver Descola, 2012, 339-41. 
Artigo original

Hegemonia - Revista Eletrônica de Relações Internacionais do Centro Universitário Unieuro

ISSN: $1809-1261$

UNIEURO, Brasília, número Especial, 2016, pp. 121-174.

de $6 \mathrm{~km}$. cada hora; hasta Pucallpa siete días en embarcación común; y hasta la ciudad de Yurimaguas (Provincia de Alto Amazonas) aunque la distancia es más corta pues son 388 km., por ser muy corriente arriba demora 4 días de lancha.

Iquitos es la sede capital del depártamento de Loreto, donde funcionó la célebre Fiscalía de Iquitos, que a fines del siglo XIX procesó judicialmente a los caucheros esclavistas sin que ninguno de los inculpados purgara sus crímenes. Descendiendo entonces por el Amazonas, en su margen o vertiente derecha topamos con la boca del río Yavarí, provincia Mariscal Ramón Castilla del Departamento de Loreto, donde nos encontramos con la Isla de Santa Rosa del Yavary (90 msnm, 2.500 h., calados de 0,80 m.), frente a las ciudades de Tabatinga y Leticia, y con el puerto Benjamin Constant. El río Yavarí de color cepia consta de $930 \mathrm{~km}$ de longitud y está formado de la unión de los ríos Gálvez y Yaquerana. ${ }^{62}$ Remontando el Yavarí damos con la localidad de Santa Fe Islandia (2.310 h.), que suma en el lado peruano un total de $5.000 \mathrm{~h}$. (el lado brasileño del Yavari lo estudiamos cuando tratamos el primer afluente del cuarto tramo o corredor brasilero), y entre ellos el grupo étnico yagua de la familia lingüística peba. ${ }^{63}$ Finalmente, para el segundo tramo alcanzamos una totalidad de $600.000 \mathrm{~h}$.

Bajando por el Amazonas damos por la margen izquierda con el tercer afluente, el río Napo, un río de llanura rodeado de territorios de selva

\footnotetext{
62 Perea Borda, 1998, 166.

63 para la construcción de cultura para el consumo y el turismo étnico entre los yagua, ver Chaparro Ortiz de Zevallos, 2008.
} 
Artigo original

Hegemonia - Revista Eletrônica de Relações Internacionais do Centro Universitário Unieuro

ISSN: $1809-1261$

UNIEURO, Brasília, número Especial, 2016, pp. 121-174.

baja, cuya naciente (encuentro de los ríos Anzu y Verdeyacu) se encuentra en los Andes Ecuatorianos (volcán Cotopaxi tenido por montaña sagrada), y cuya boca fuera copada por el Perú desde Iquitos (en un mecanismo muy semejante al que Brasil practicara desde Manaos con el Putumayo). ${ }^{64}$ Remontándolo, alcanzamos río arriba, en la región del Alto Napo, a Puerto Arica, a la altura de Flor de Agosto (sobre el Putumayo), y luego con Santa Felicia, Santa Clotilde, y con la última localidad peruana, en la confluencia por su margen izquierdo con el río Aguarico, el embarcadero Cabo Pantoja ( $89 \mathrm{msnm}$ y capital del distrito Torres Causana, provincia de Maynas). Una vez en el Ecuador amazónico, en la desembocadura del río Mazán, damos primero con Puca Urco (105 msnm y 13098 h.), distrito de Alto Nanay, provincia de Maynas; luego con Puerto Pompeya; más arriba por su margen izquierda con el río Tamboryacu, y su poblado Moñoz de Tamboryacu, donde se da la interconexión Tamboryacu-Campuya (Napo-Putumayo), y con la desembocadura del río Curaray, con Nuevo Rocafuerte (200 msnm), y con El Coca o puerto Francisco de Orellana (255 msnm y 2.131 h., navegado por embarcaciones de hasta 3 pies de calado en la época de menos caudal), muy poblado por grupos étnicos, entre los cuales se destacan los Huaorani o Waorani, llamados peyorativamente "aucas", y los Taromenane con quienes entraron recientemente en guerra, escenario de una producción cinematográfica titulada "Soy Huao", del cineasta argentino Juan Baldana; y también la del italiano Carlos Crespi "Los invencibles shuaras del Alto Amazonas" estrenada en 1926; la del naturalista sueco Rolf Blomberg "En canoa a la tierra de los reductores de cabezas", de

${ }^{64}$ para llegar a Puerto Campuya en el Putumayo se requieren 29 días de navegación, y se ha programado un atajo con un canal piloto a través del cual se llegaría en sólo un día y medio, ver Perea Borda, 1998, 156. 
Artigo original

Hegemonia - Revista Eletrônica de Relações Internacionais do Centro Universitário Unieuro

ISSN: $1809-1261$

UNIEURO, Brasília, número Especial, 2016, pp. 121-174.

1937; la de Elisabeth Elliot, viuda de uno de los cinco sacrificados en 1955 "Por las puertas del esplendor"; la del ecuatoriano Omar Burneo "Los shuar"; y finalmente la del indígena Eriberto Gualinga "Soy Defensor de la selva, estrenada en 2003.65 También se destacan multitud de etnías de origen preincaico, como por ejemplo los omaguas-yetes (cazadores de esclavos), los záparos (productores de hamacas), ${ }^{66}$ encabellados, abjiras, payaguas, ciecoyas, icahuates, ciguagues, guaciguagues, y masamaes. ${ }^{67} \mathrm{Y}$ remontando el Napo, en la región del Alto Napo, abordamos la boca de varios sub-afluentes, el río Payamino y, justo al lado, el río Coca o Papallacta, y más adelante el Aguarico (la confluencia con el Coca es el factor geográfico que divide el curso del Napo en dos partes: el Alto Napo y el Bajo Napo). ${ }^{68}$

Y descendiendo una vez más por el Amazonas, pero ensanchándose al extremo de no visualizarse ya sus orillas ( $4 \mathrm{~km}$ de anchor), habiendo dejado el Perú, se alcanza el corredor amazónico colombiano, las regiones de selva baja menos urbanizadas de la Amazonía, poblada por numerosas etnías indígenas, que fueron duramente diezmadas durante la Fiebre del

\footnotetext{
65 ver Rival, 1998 y 2012; y Doughty, 2010; para la resistancia de la communidad huaorani, ver Ziegler-Otero y Ziegler-Otero, 2004; y para la etnomedicina de los waorani del Ecuador amazónico, ver Davis y Yost, 1983. Para una breve historia del documentalismo ecuatoriano, ver Larrea Arias, 2012.

${ }^{66}$ ver Eriksen, 2011, 50.

67 para las exploraciones de las regiones ecuatoriales a lo largo del Napo, ver Osculati, 2003; para la complejidad social en las estribaciones andinas orientales durante el período pre-incaico tardío, ver Lara, 2010; y para la relación entre parentesco y lenguaje en el Alto Napo, ver Uzendoski, 2006.

68 para la cosmovisión y participación política de los indígenas en el Ecuador, ver Hidalgo, 2006.
} 
Artigo original

Hegemonia - Revista Eletrônica de Relações Internacionais do Centro Universitário Unieuro

ISSN: $1809-1261$

UNIEURO, Brasília, número Especial, 2016, pp. 121-174.

Caucho (pero que con posterioridad se recuperó asombrosamente, pues los puertos actuales revelan una población muy sostenida).

\section{A-III.-Tercer tramo o corredor colombiano-brasileño, de selva baja, exogámico y multilingüe (Mapa IV).}

Dejaríamos entonces los ríos de montaña, los que se transformarían ahora en ríos de llanura selvática, de intensa selva baja, alcanzando el tercer tramo del circuito amazónico-platino la llamada Colombia amazónica. Esta inmensa región se caracteriza por la combinación de tres (3) grandes afluentes y redes de drenaje (Putumayo, Caquetá y Negro), localizadas en el largo y extenso arco o curva continua que da el Amazonas entre la desembocadura del Napo y la boca del río Negro. Para su descripción, debemos ordenar los ríos en cinco (5) variantes, de oeste a este, desde las márgenes o vertientes izquierdas de los ríos de llanura a las márgenes derechas de los mismos, desde su desembocadura hasta sus propias nacientes o cabeceras, en su direccionamiento ya sea río arriba o río abajo, se trate de ríos meándricos o anastomozados, y en la distinción ecológica y étnico-demográfica del hábitat, se trate de "tierra firme" (no inundable, poblada por las etnías tikunas, yaguas y mayorunas o matsés) o de "zona de várzea" (ribereña, poblada por las etnías omaguas o guaraníes, cazadores de esclavos, enemigos de los tikunas), y por los cocama, cocamilla, ibanomas, y yurimaguas [en tiempos del P. Fritz los yurimaguas fueron desterritorializados y destribalizados y trasladados a 
Artigo original

Hegemonia - Revista Eletrônica de Relações Internacionais do Centro Universitário Unieuro

ISSN: $1809-1261$

UNIEURO, Brasília, número Especial, 2016, pp. 121-174.

la cuenca del Huallaga]), y por grupos étnicos diferenciados y rivales entre sí. ${ }^{69}$

En ese detallado orden geográfico, ecológico, y cartográfico (topónimos y nomenclaturas) con sus derivaciones chamánicas, farmacológicas y etnobotánicas alcanzamos las bocas de los ríos Putumayo/Içà, Caquetá/Japurá, y Guainia/Negro, cuyas nacientes y sus cabeceras administrativas se encontraban en las muy lejanas faldas de la cordillera oriental colombiana. Sin duda esta lejanía y la ausencia de una jurisdicción amazónica como Manaos en Brasil, Puerto Trinidad (Beni) en Bolivia, o Iquitos en Perú, fue la principal dificultad de las autoridades neogranadinas y colombianas, incluidas las autoridades de la orden capuchina, para generar en los siglos XIX y XX un interés regional propio. Sus largos, oblícuos y lentos drenajes en la curvatura del río Amazonas, con abundantes humedales y con semejanzas en la representación cartográfica a una bayoneta calada, río que viene ascendiendo de este a oeste, pero que luego tras el giro hídrico va remontando en dirección norte-sur, en un movimiento geológico muy semejante al del río Orinoco, que le permite ir capturando todos los ríos que en el Perú bajan de los Andes (Napo, Marañón, Urubamba, Apurimac). Este circuito del Amazonas, entre la boca del Napo y la del Negro estuvo siempre desde el siglo XVII disputado política y militarmente por la potencia lusitana, pues primero en 1743 alcanzó a controlar la desembocadura del Negro; poco después y río arriba la boca del Japurá/Caquetá; y luego con la Paz de Paris, en 1762, más río arriba aún, las bocas del Putumayo y del Yavarí,

69 Zárate Botía, 2001, 235. 
Artigo original

Hegemonia - Revista Eletrônica de Relações Internacionais do Centro Universitário Unieuro

ISSN: $1809-1261$

UNIEURO, Brasília, número Especial, 2016, pp. 121-174.

con la retención de Tabatinga pese a lo dispuesto por el Tratado de Madrid de $1750 . .^{70}$

Más abajo de la desembocadura del Napo, a orillas del Amazonas, en su margen izquierda, llegamos primero a la boca del río Loretoyacu, a cuyas orillas se halla Puerto Nariño (159 msnm y 6.983 h.), antiguo Puerto Espejo, el "pesebre del Amazonas", y luego más abajo del Amazonas la ciudad de Leticia (90 msnm y 37.832 h., fundada por los peruanos pero transferida a Colombia por el presidente Augusto Leguía conjuntamente con el territorio que comprende el Trapecio Amazónico, a cambio del Triángulo de Sucumbíos (frontera con Ecuador), por virtud del Tratado Salomón-Lozano de 1927.71 Leticia e Iquitos están separadas por 370 km., y está ubicada frente a la desembocadura del río Yavarí, la ciudad peruana de Ramón Castilla y la aldea misionera de Tabatinga, fundada en el siglo XVII y transformada en vila en 1759 (de Tabatinga a Iquitos 370 km. con calado de 5 m., y de Tabatinga hasta Manaos 1069 km. con calado de 6 a $8 \mathrm{~m}$.), la cual había sido reforzada militarmente por Pedro II en 1867 de manera tal de capturar la boca del Putumayo frente a la desembocadura del río Tonantins. ${ }^{72}$ Tabatinga es también la sede del Museo Etnográfico del Hombre Amazónico, ubicado en la Biblioteca del Banco de la República. El río Içà-Putumayo es un río internacional (significa en quechua río de vasija de fruto de árboles) que bordea desde su boca en el Amazonas cuatro países: Brasil, Colombia, Perú y Ecuador;

\footnotetext{
70 Zárate Botía, 2001, 254.

71 ver Uribe Mosquera, 2013, 41.

72 para las tres ciudades gemelas del Amazonas y su rol como mercado financiero del narcotráfico, ver Gemaque Souza, 2014, 73.
} 
Artigo original

Hegemonia - Revista Eletrônica de Relações Internacionais do Centro Universitário Unieuro

ISSN: $1809-1261$

UNIEURO, Brasília, número Especial, 2016, pp. 121-174.

que en Brasil se llama Içà, como lo denominaban los indios omahuas (de familia guaraní), y que al remontar en dirección a Colombia, al norte de Leticia, cambia de nombre llamándose Putumayo. ${ }^{73}$

Los pobladores de esta región pertenecen a grupos étnicos de la familia makuna (con malocas rectangulares), y de la familia tucano oriental (tanimuca, letuama, cabiyari, yuhup, yauna, con malocas circulares), y estuvieron al comienzo bajo la jurisdicción Popayaneja de San Juan de Pasto y más recientemente bajo la jurisdicción de la ciudad de Florencia (fundada en 1902), capital del departamento del Caquetá y puerta de entrada a la Amazonía colombiana (también estuvo bajo esa jurisdicción la familia Tucano Occidental de los siona y los coreguajes, originarios del río Caguán y luego trasladados por el asedio de los caucheros a las orillas del Orteguaza). ${ }^{74}$ De todas las regiones amazónicas, la colombiana fue la más trágicamente vulnerable a la penetración lusitana y a la cacería de esclavos para las plantaciones azucareras del nordeste, por la circunstancia de haber controlado Portugal/Brasil desde el Tratado de Madrid (1750) --pero más fuertemente desde que Pedro II reforzó Tabatinga--la boca de los tres ríos que vienen de Colombia, primero lo fue el Negro, luego río arriba el Caquetá, y más arriba el Putumayo. Pretendió también Portugal controlar la boca del río Napo pero fracasó en

\footnotetext{
73 Perea Borda, 1998, 143. Para la conservación de la diversidad biológica, botánica, zoológica y cultural en el piedemonte amazónico colombiano y la herencia del botánico Richard Evans Schultes, ver Zuluaga Ramírez, 2005.

74 La terminación guaje significa "gente" (Chaves Ch. y Vieco A., 1987). Y para la etnohistoria de los coreguajes del piedemonte subandino amazónico colombiano, ver Marín Silva, 2013, 2014.
} 
Artigo original

Hegemonia - Revista Eletrônica de Relações Internacionais do Centro Universitário Unieuro

ISSN: $1809-1261$

UNIEURO, Brasília, número Especial, 2016, pp. 121-174.

el intento, y Brasil buscó recién entonces, infructuosamente, asignar esos territorios a Ecuador. ${ }^{75}$

Se debe señalar lo que el colombiano Germán Grisales (2008) viene sosteniendo desde hace un tiempo, las frontera entre Brasil y Colombia fue delimitada por ambos países sin que sus dirigentes la conocieran personalmente y sin tampoco conocer a sus pobladores autóctonos, quienes fueron las víctimas de estos trazados cartográficos, pues en muchos casos incluso se los desterritorializó. En ese sentido, las Misiones Jesuíticas --cuando arreciaban las cacerías de esclavos por parte de los bandeirantes y los sertanistas de contrato-- se ofrecían a los grupos étnicos como santuarios y oficiaban también como impulsoras de expediciones para recolectar sal y otras especies caras a la vida doméstica indígena (que se solía cocinar mediante la técnica culinaria del moqueado). Las rutas comerciales y comunicacionales frecuentadas por las Misiones Jesuíticas, una vez que se los expulsó fueron asumidas como propias por los comerciantes criollos o blancos, y por los llamados cacharreros, comerciantes minoristas que traficaban en grandes canoas atoldadas, en forma ambulante. ${ }^{76}$

Fue esta región, primero el escenario del boom de la zarzaparrilla, el cacao, la cascarilla, la quina (1830-1880), luego la fiebre cauchera (18801912), en la década del 70 la fiebre petrolera y también la pugna pseudoreligiosa entre el Instituto Lingüístico de Verano (ILV), de filiación

\footnotetext{
75 Zárate Botía, 2001, 246.

76 Eriksen, 2011, 49-51.
} 
Artigo original

Hegemonia - Revista Eletrônica de Relações Internacionais do Centro Universitário Unieuro

ISSN: $1809-1261$

UNIEURO, Brasília, número Especial, 2016, pp. 121-174.

evangelista, y los Javerianos de Yarumal (católicos conservadores del Instituto de Misiones Extranjeras), luego de la Guerra de 1932 entre Perú y Colombia, y recientemente del narco-paramilitarismo anti-guerrillero de Gonzalo Rodríguez Gacha. ${ }^{77}$ La fiebre cauchera había intensificado las migraciones internas a través de los ríos de la cuenca, y ocasionó un genocidio practicado por la peruana Casa Arana y sus socios británicos, y un desplazamiento forzado vía fluvial, al sur del Putumayo (al río Momón afluente del Nanay, pero procedentes del río Ampiyacu, en el departamento de Loreto), de miles de familias uitotos, boras y ocaínas, tragedia que dejó su secuela indeleble hasta la propia actualidad. ${ }^{78}$

Llegando a la boca del primer afluente, el río Putumayo-Içá (o en quechua río de las vasijas, el más navegable en sus $1.850 \mathrm{~km}$. de longitud pero de escurrimiento lento, y a diferencia del Caquetá carece en el Medio y BajoPutumayo de sub-afluentes significativos), y remontando la margen izquierda o septentrional del mismo (que tiene la barranca más alta que el margen derecho o meridional del río) se alcanzan primero el destacamento militar brasilero de Ipiranga, y luego cruzando la despoblada frontera con Colombia, donde la infraestructura portuaria existe solo en la margen colombiana, que es la más alta, se llega en el Bajo Putumayo a Tarapacá ( 96 msnm y $3.950 \mathrm{~h}$. navegado por barcos de 6 pies [1,8 m.] de calado), a La Pedrera (100 msnm y 4985 h. ), a Puerto Arturo (140 msnm), y luego más arriba a la estación Indiana de Benjamín Larrañaga, que luego pasó a manos de la Casa Arana renombrada La

\footnotetext{
77 ver Stoll, 1985.
}

78 Pineda, 2000; Stanfield, 2009; y Polanco Ochoa, 2013; sobre Roger Casement y EI Sueño del Celta de Vargas Llosa, ver Lesmes Guerrero, 2012; y para el testimonio de Ramiro Rojas Brown, nieto del testigo que informó a Roger Casement, ver Gómez J., 2013. 
Artigo original

Hegemonia - Revista Eletrônica de Relações Internacionais do Centro Universitário Unieuro

ISSN: $1809-1261$

UNIEURO, Brasília, número Especial, 2016, pp. 121-174.

Chorrera (184 msnm), en el curso medio del sub-afluente Igara Paraná, y Puerto Campuya; y más arriba a El Encanto, a orillas del sub-afluente Cará Paraná (escenario de la resistencia del jefe witoto Nofurema), ${ }^{79}$ y más arriba aún al puerto de Leguízamo (177 msnm y 46.602 h.), ex colonia Caucayá, y luego al puerto de Ospina (182 msnm y 1.250 h., frente a la localidad ecuatoriana de Puerto Carmen del Putumayo, cerca de donde desagua por la margen derecha el río San Miguel, navegado por embarcaciones de cuatro pies de calado y con muelle propio).

Más arriba, en el Medio Putumayo, se encuentran Puerto Asís (250 msnm y 55.759h., a $400 \mathrm{~km}$ de Leguízamo, fundado en 1912 por los Misioneros Capuchinos), Puerto Caicedo (290 msnm, 14.206 h., antiguamente caserío El Achiote), Orito (310 msnm y 19.179 h., con explotación petrolífera), Villagarzón (426 msnm y 9342 h.), Puerto Guzmán (557 msnm y 22.679 h. ), y los rastros donde antaño estuvo la colonia penal de La Tagua, que suman en toda la cuenca del Putumayo $103.611 \mathrm{~h}$. Leguízamo se llamaba antiguamente La Perdiz y luego Puerto Caucayá o río de las garzas, en lengua siona, y es la sede colombiana de la Fuerza Naval del Sur, cuya mira está puesta en la guerrilla de las Farc, en el narcotráfico y en la minería ilegal. ${ }^{80}$ En materia de distancias y duración de navegación, desde Puerto Leguízamo bajando hasta su desembocadura en el río Amazonas, próximo a la ciudad de Santo Antônio do Içá (75 msnm y 24.000 h.), y siguiendo el trayecto río arriba por el Amazonas hasta la ciudad de Leticia, unos dos mil km., se empleaba en

\footnotetext{
79 Ver Calle Restrepo, 1970.

${ }^{80}$ para el desplazamiento forzado de los grupos étnicos, ver Soledad Suescún y Egea Jiménez, 2008.
} 
Artigo original

Hegemonia - Revista Eletrônica de Relações Internacionais do Centro Universitário Unieuro

ISSN: $1809-1261$

UNIEURO, Brasília, número Especial, 2016, pp. 121-174.

promedio un lapso de diez días; y hasta Iquitos llevaba quince días de navegación o sea cinco días más (a razón de $200 \mathrm{~km}$. por día u ocho km. cada hora, precisando que río arriba insumía casi el doble de tiempo que río abajo, a razón de $5 \mathrm{~km}$. por hora en vapor de línea), lugar donde los precios eran más razonables que en Manaos. ${ }^{81}$

Paralelamente, remontando el Putumayo por su margen derecha o meridional y en territorio peruano, atravesamos desde la desembocadura del río Yaguas y a lo largo de 1380 km, en el Bajo Putumayo las localidades de Remanso, San Antonio del Estrecho (8000 h.), Puerto Limón (126 msnm), y Flor de Agosto (118 msnm y 414 h.), donde se encuentra la interconexión Vidal Sangano - Flor De Agosto que conecta con el río Napo. Y en el Medio Putumayo atrsavesamos la localidad de Angusilla (225 msnm), y alcanzamos la desembocadura del río Güeppi, punto fronterizo tripartito o triple frontera entre Perú, Colombia, y Ecuador (hasta Gueppí pueden llegar embarcaciones de 4 pies de calado). A la vera del río Putumayo, pero en territorio ecuatoriano, se llega a Puerto El Carmen de Putumayo (230 msnm, 198 h., y de hasta 3 pies de calado en la época de menos caudal), famoso por regir la regla "ver, oir y callar". Más arriba, donde el río Putumayo es colombiano en ambos márgenes y se lo conoce por el Alto Putumayo o Valle de Sibundoy (o la Suiza de Colombia), se llega --luego de haber fatigado la más extensa región amazónica de selva baja y suelos arenosos-- a la ciudad de Mocoa (595 msnm y 48.000 h.), capital del Departamento de Putumayo,

81 Pineda Camacho, 1988. 
Artigo original

Hegemonia - Revista Eletrônica de Relações Internacionais do Centro Universitário Unieuro

ISSN : $1809-1261$

UNIEURO, Brasília, número Especial, 2016, pp. 121-174.

escindida a partir de 1845 de la provincia de Popayán (sobre la ribera del río Mocoa), a la altura de las bocas de los ríos Mulato y Sangoyaco.

Volviendo al Amazonas, llegando río abajo a la boca del segundo afluente, el río Caquetá/Japurá, cuyas aguas proceden del macizo cordillerano y de la planicie sabánica, y que en Colombia separa sus departamentos de Amazonas y Caquetá (es un río de aguas blancas o limosas, y a diferencia del Putumayo le sobran sub-afluentes significativos). Este afluente, en Brasil, se convierte en un río anastomosado o trenzado, pues desagua en varios brazos (entre ellos el Tarara y el Ararapú, los únicos navegables), en forma de delta, y desemboca frente a la ciudad brasilera de Tracuatuva de Tefé o Tefé, que fuera fundada por el padre jesuita Samuel Fritz. ${ }^{82}$ Remontando el Japurá/Caquetá, en la región del Bajo Caquetá, se llega primero al destacamento militar brasilero de Vila Bittencourt (60 msnm, km 747 y 600 h., con barcos de 1, 20 m de calado), y más arriba cruzando la frontera con Colombia se alcanza el célebre pueblo mestizo de La Pedrera (200 h.), las Serranías del Araracuara (hogar o nido de las guacamayas y también colonia penal) y de Cupatí, escenario de los incidentes militares con el ejército peruano en 1911, conocido como Conflicto de La Pedrera, y citado en las narraciones del escritor colombiano Germán Castro Caycedo (Perdido en el Amazonas y Mi alma

\footnotetext{
82 Ver Mejía Valenzuela, 1983. Para la construcción del territorio amazónico colombiano del Caquetá, ver Llanos y Pineda, 1982; y Arcila Niño, et.al., 2000.
} 
Artigo original

Hegemonia - Revista Eletrônica de Relações Internacionais do Centro Universitário Unieuro

ISSN: $1809-1261$

UNIEURO, Brasília, número Especial, 2016, pp. 121-174.

se la dejo al diablo). ${ }^{83}$ La Pedrera se encuentra frente al Cerro Yupatí, lugar sagrado para las etnias indígenas de la región del Caquetá y el Apaporis. ${ }^{84}$

Río arriba en el Bajo Caquetá se llega a la boca del sub-afluente río Apaporis, donde cerca de su estuario o Bajo Apaporis se había radicado a principios del siglo XX la Casa cauchera Calderón, que luego fue fagocitada por la Casa Arana. ${ }^{85}$ Es necesario pensar el eje fluvial del río Amazonas como la columna vertebral de un sistema de humedales sudamericanos que tiene al cananguchal de San Vicente del Caguán (Caquetá, escenario de las FARC y su guerrilla) como componente Oeste, al delta del río Beni (Pampas del Yacuma) como componente sur, y al gran archipiélago de Marajó al oriente, en la boca del Amazonas. ${ }^{86}$ Remontando el curso del Bajo Apaporis, que son aguas negras, tal como nos ilustra el geógrafo Domínguez Ossa (1975), se alcanza por el margen izquierdo el río Cananarí con la población de los Kavillarí, las localidades de Ocaso y Buenos Aires de Lérida, y la desembocadura del río Patá; y más arriba tropezamos con el raudal del Yavareté, y con el río Jotaveyá, con la población Makú de la familia lingüística Puinave.

\footnotetext{
83 se entiende por Bajo Caquetá-Putumayo la faja propiamente ecuatorial, localizada al oriente del río Caguán (afluente del Caquetá), y del río Caucayá (tributario del Putumayo), definida, en su otro costado, por la frontera colombo-brasilera. Para una lectura sociológica de la obra de Castro Caycedo, ver Gómez-Quintero, 2009.

84 Para una visión antropo-geográfica del río Apaporis, ver Domínguez Ossa, 1975.

85 Hildebrand y Reichel, 1987.

${ }^{86}$ Para el manejo indígena de la fauna en el medio y bajo río Caquetá, ver Rodríguez, y van der Hammen, 2012.
} 
Artigo original

Hegemonia - Revista Eletrônica de Relações Internacionais do Centro Universitário Unieuro

ISSN: $1809-1261$

UNIEURO, Brasília, número Especial, 2016, pp. 121-174.

En la región del Apaporis Medio, ahora objeto de un documental por el realizador inglés Mike Slee, titulado "Colombia Magia Salvaje", filmado entre las Cachiberas del Venado (que el botánico Schultes bautizara en 1940 como Chiribiquete, declarado recientemente Parque Nacional Natural, entre los ríos Apaporis y Mesay, afluente del Yarí, por su riqueza pictográfica de miles de petroglifos o pinturas rupestres milenarias) y los saltos del Jirijirimo, en un tepuy amazónico, perteneciente -a juicio de Castaño-Uribe-- a la Formación Roraima y al propio Escudo de Guyana, es decir con basamentos geológicos del precámbrico y del paleozoico, y que se ha llegado a conocer como la "Capilla Sixtina de la Amazonía".87 En esa región, poblada por los indios Karijona (de filiación macro lingüística Karibe), el Apaporis Medio recibe por el lado izquierdo al subafluente Pirá-Paraná, que es un río con aguas "color de té bien macerado que fluye en un lecho de arena blanca". ${ }^{88}$ Más arriba, por la margen derecha se llega a los afluentes Yapiyá, Popeyacá e Icapuyá, con las poblaciones de los Tanimuka, los Letuama y los Yáuna, de la familia lingüística Tukano oriental (la conexión natural del río Cananarí, afluente del Apaporis, con las cabeceras de los afluentes del río Vaupés nunca fue encontrada). 89

Y más arriba aún, en la región del Alto Apaporis, se alcanza el río Tunia o Tunha, que atraviesa las sabanas del Yari, y llega al río Macayá. Río arriba

\footnotetext{
87 Para la tradición cultural Chiribiquete, ver Castaño-Uribe, 2008. Las pictografías fueron pioneramente publicadas por Carlos Castaño y Thomas van der Hammen, entre 1990 y 1992.

${ }^{88}$ para el conocimiento de los chamanes de Yurupari, en el Pirá-Paraná, ver Cayón, 2002; y Rodríguez Pérez, 2015.

${ }^{89}$ Ver Cayón, 2013, 94.
} 
Artigo original

Hegemonia - Revista Eletrônica de Relações Internacionais do Centro Universitário Unieuro

ISSN: $1809-1261$

UNIEURO, Brasília, número Especial, 2016, pp. 121-174.

en el Alto Caquetá se llega a la boca de los sub-afluentes ríos Yarí y Caguán, y remontándolos se alcanza a San Vicente del Caguán (490 msnm y 56.000 h.), área cenagosa cubierta de cananguchales o aguajales (bosques de pantano sobre suelos anegados, turbosos, valles aluviales y terrazas bajas en la región de la amazonia colombiana), y que estuvo confiado desde 1896 al cuidado pastoral de los misioneros Capuchinos, y posteriormente sede del Vicariato Apostólico. Por último, tras unas colinas se halla la divisoria con los afluentes del Guaviare, como el río Losada, que pertenecen a la cuenca del Orinoco y es frontera entre los departamentos del Guaviare y del Caquetá. ${ }^{90}$

Las franjas de transición entre la selva y la sabana son zonas de arenas blancas con escasa vegetación, conocidas como caatingas, así como los tepuyes, formaciones precámbricas del Escudo de Guayana, formadas de sur a norte por las cuencas de los ríos Guaviare, Inírida, Matavén, Vichada, Meta y Arauca, que pertenecen a la Orinoquía, pues son cursos de agua que drenan hacia el río Orinoco, río que desde el Atlántico viene ascendiendo de oriente a occidente, pero que luego va girando del norte hacia el sur, en un movimiento hidrográfico muy semejante al del río Amazonas, que le permite ir capturando todos los ríos mencionados, que en la Nueva Granda (Colombia) bajan de los Andes.

Luego, más arriba en el Bajo Caquetá, se llega a la boca del sub-afluente Mirití-Paraná donde se había instalado la Casa cauchera de Oliverio Cabrera (también adquirida por la Casa Arana) y más tarde el Instituto Lingüístico de Verano (ILV), y más arriba aún, en la región del Bajo Mirití,

90 ver Domínguez Ossa, 1975, 135. 
Artigo original

Hegemonia - Revista Eletrônica de Relações Internacionais do Centro Universitário Unieuro

ISSN: $1809-1261$

UNIEURO, Brasília, número Especial, 2016, pp. 121-174.

se llega a los caseríos de Puerto Caimán, y Bocas de Cahuinari (14 h.), donde se asienta la etnía Miraña, otrora antropófaga; y también los Andoque, conocidos en la antigüedad como proveedores de hachas de piedra y ambos de habla bora-huitoto, que habitaban en los sub-afluentes Monochoa, Aduche y Quinché, tributarios del Caquetá. Remontando su sub-afluente el río Mirití-Paraná se llega a las etnias Yukuna y Matapí, de la familia lingüística arawak (que viven de la subienda de los peces que desovan en los cananguchales), y en su afluente el río Komeñaca gran parte de la población Tanimuka, Ilamados también Ufaina o "gente ceniza", más arriba se llega al chorro o salto del Tequendama (cascada natural de 156 metros de altura), y más arriba aún en el Alto Mirití, vivían los Yukuna, grandes canoeros expertos en sortear saltos de agua, desde donde bajaron impulsados por la oferta de trabajo siringuero. ${ }^{91} \mathrm{Y}$ navegando en el río Caquetá, mucho más arriba, se llega a la boca de los ríos Yari (o río de los Engaños), Caguán y Orteguaza, y en la desembocadura de este último la población mestiza de Solano (203 msnm y 23.000 h.). Finalmente, remontando el último tramo del Alto Caquetá y siempre en selva baja y suelos arenosos se llega a Florencia (242 msnm y 163.323 h.), capital del departamento de Caquetá, en la margen derecha del río Hacha, conocida como «La Puerta de Oro de la Amazonia Colombiana».

En este tercer tramo o corredor colombiano-brasileño, mientras la población residente en las riberas del río Putumayo (Colombia, en Brasil se lo conoce como río Içá) es de 103.611 h., la del departamento

91 para el chamanismo nocturno de los Yukuna, ver Fontaine, 2014. Llegaron a ajusticiar en 1908 al patrón cauchero Braulio Borrero (Pineda Camacho, 1988) 
Artigo original

Hegemonia - Revista Eletrônica de Relações Internacionais do Centro Universitário Unieuro

ISSN: $1809-1261$

UNIEURO, Brasília, número Especial, 2016, pp. 121-174.

Amazonas en Colombia, es casi nueve veces mayor, pues cuenta con un total de 892.392 h. Esta abrumadora diferencia obedecería a que no hemos computado las poblaciones ribereñas de los ríos Apaporis, y Caquetá (en Brasil se lo conoce como Japurá). En el caso del río Apaporis, los numerosos grupos étnico-lingüísticos de la familia Tucano Oriental (makuna, tanimuca, letuama, cabiyari, yuhup y yaúna), están escasamente receptivos con la civilización moderna debido a su tenaz aislamiento. ${ }^{92}$

Volviendo al río Amazonas, bajando por su margen izquierda, se llega a la boca del tercer afluente, el río Negro, cuyas aguas proceden de las planicies sabánicas (río Vaupés) y del macizo guayanés (río Branco), y que entre sí mantienen una diferencia de calado o profundidad y de temperatura. En materia de calado, existe una diferencia de 20 metros (mientras el Solimoes tiene 55 mts, el Negro tiene $35 \mathrm{mts}$ ), y en materia de temperatura de 6 grados, capaz esta última de generar energía térmica. ${ }^{93}$ Ascendiendo el río Negro se atraviesan primero el Archipiélago de Anavilhanas, y luego las localidades brasileras de São Joaquim, ${ }^{94}$ Açai Paraná, Tuluca, y Paraná Juca, y más luego las localidades de Puraquê, Ponta Cuiubí e Iauaretê, en el estado de Amazonas, donde deja de ser territorio brasilero y cruza a Colombia. En los márgenes de este afluente,

\footnotetext{
92 sobre el aislamiento de los tucano, ver Landaburu, 2004-2005; sobre el motivo porqué migran los tucano, ver Brandhuber, 1999; y sobre la lengua, la cultura y la sociedad entre los yuhup, ver Ospina Bozzi, 2008. Sobre los Makuna, ver Cayón, 2008 y 2009.

93 Para la energía en la confluencia de los ríos Negro y Solimões, ver Beluco y Kroeff de Souza, 2014.

94 grupos étnicos Kuripaco de la cosmogonía Yekuana o Makiritare, y Baniwa, ver Wright, 1998.
} 
Artigo original

Hegemonia - Revista Eletrônica de Relações Internacionais do Centro Universitário Unieuro

ISSN: $1809-1261$

UNIEURO, Brasília, número Especial, 2016, pp. 121-174.

con motivo del Tratado de Madrid de 1750, los bandeirantes portugueses habían desplazado cantidad de grupos étnicos para llevarlos como esclavos al Pará. 95

Remontando ahora el río Negro en territorio colombiano (o río Guainía en Colombia, de intenso color oscuro y bajo contenido de nutrientes), se llega primero a su sub-afluente el río Vaupés (cuyos afluentes y sus cabeceras se especuló tenían un canal natural que los unía con el río Cananrí, afluente del río Apaporis), ${ }^{96}$ y luego al sub-afluente río Içana, donde los indígenas practicaban el ritual de Yuruparí, ${ }^{97}$ en el mismo territorio que fuera área de influencia del prolífico y singular cauchero español Germino Garrido y Otero, y que fuera recorrido en el siglo XIX por el naturalista inglés Alfred Russel Wallace (el padre de la biogeografía) y sus compatriotas el botánico Richard Spruce y el entomólogo Henry Walter Bates, y el etnólogo alemán Theodor Koch-Grünberg. Últimamente ha sido el escenario de una producción cinematográfica premiada en el Festival de Cannes, titulada "El abrazo de la serpiente" del cineasta colombiano Ciro Guerra, en donde se retratan las epopeyas científicas del etnólogo alemán Koch-Grünberg y del botánico Richard Evans Schultes. Esta región del Vaupés, luego de 1910, fue dividida entre los salesianos auspiciados por los brasileños, y los padres monfortianos alentados por Colombia, luego reemplazados por los Javerianos. ${ }^{98}$

\footnotetext{
95 Zárate Botía, 2001, 251.

96 Ver Cayón, 2013, 94.

97 Para el mito y ritual del Yurucarí, ver Del Cairo Silva, 2003.

98 Ver Pineda Camacho, 1988; y Zuluaga Ramírez, 2009.
} 
Artigo original

Hegemonia - Revista Eletrônica de Relações Internacionais do Centro Universitário Unieuro

ISSN: $1809-1261$

UNIEURO, Brasília, número Especial, 2016, pp. 121-174.

En este tramo se alcanza la localidad de Santa Isabel de Río Negro (71 msnm, y 18.506 h.), y la de Barcellos (75 msnm y 27.273 h.). Esta última tuvo origen en una aldea de los indios Manaus, llamada Mariuá (localidad y archipiélago hasta donde había concurrido el medio hermano de Pombal el Gobernador del Pará Francisco Xavier de Mendonça Furtado), y que fue elevada a la categoría de villa con el nombre de Sao José da Barra do Río Negro. Y mucho más arriba se localiza la población de São Gabriel da

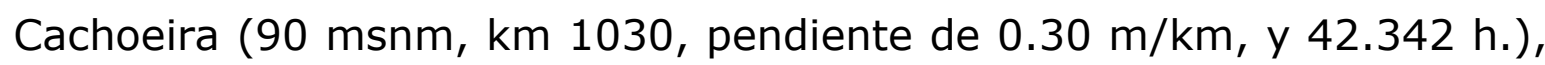
que totalizan unos 100.000 h. ${ }^{99}$ Este es un territorio rico en mineral de nióbio, donde se encuentra el corregimiento departamental Miriti-Paraná habitado por indígenas cubeos o kubeos (a lo largo de los sub-afluentes Caduyarí, Querarí, Pirabotón y Cabiyú), desanos (en los igarapés o caños Abiyú, Cucurá, Timbó y Murutinga), piratapuyos (oriundos del río Papurí, en ellos prevalece el rito o ceremonial con flautas de carrizo y caparazón de tortuga), carijonas (Huaques ó Murciélagos, habitaron en el bajo Yarí, en serranía del Iguaje o cuenca del río Mesay, ríos Cuñaré y Amú y laguna Tunaima), y guananos, del grupo lingüístico tukano, y donde amén del portugués y el tukano se han oficializado las lenguas baniwa (arawak del río Isana) y ñeengatú o tupí amazónico, o lengua franca de la Amazonia. ${ }^{100}$ En materia fonológica, Gómez-Imbert (2011) pudo pasar -gracias al sistema matrimonial exogámico del pueblo tukano y al consiguiente multilingüismo que genera-- del dialecto tatuyo al barasano.

\footnotetext{
99 Perea Borda, 1998, 108.

100 para las políticas de la etnicidad tukana, ver Jackson, 1994; y para la lengua franca amazónica, ver Ribeiro, 2006, 111-118.
} 
Artigo original

Hegemonia - Revista Eletrônica de Relações Internacionais do Centro Universitário Unieuro

ISSN: $1809-1261$

UNIEURO, Brasília, número Especial, 2016, pp. 121-174.

Por todos estos motivos, algunos autores concluyen en que ha cundido en la Amazonia noroccidental una suerte de multilingüismo. ${ }^{101}$

En este encuentro de sub-afluentes del Amazonas, no hemos computado las poblaciones de Santa Rosa y Puerto Limón, ni tampoco los grupos étnicos de la familia Arawak como los curripaco o wakuenai (bajo río Guainía), ${ }^{102}$ productores de oro que ancestralmente intercambiaban por cerámica policromada con los Aisuari (etnía tupí) de la boca del Juruá, ${ }^{103}$ vinculados a los bare y guarekennes del río Negro, los talianas del río Vaupés, y los wenaiwika (enaguas o piapoco, de lengua arawak), que habitan entre los ríos Meta y Guaviare, afluentes del Orinoco. ${ }^{104}$ Tampoco hemos computado a los resigero (de la familia arawak) y a los huitoto o bora-witoto, el más exogámico de toda la cuenca, merced a lo cual fue capaz de resistir la adversidad y sobrevivir la explotación cauchera. ${ }^{105}$ Esta extensa región sabánica, que es una transición entre la Amazonía y la Orinoquía, se caracteriza por la existencia de tres momentos mesiánicos trascendentales, el del chamán baniwa Venancio Cristo enfrentado a los caucheros en 1857; el de Alejandro el Cristo del Vaupés (proclamaba que el orden social del mundo sería invertido transformando

101 ver Stenzel, 2005; para los indígenas del Mirití-Paraná, ver Hildebrand y Reichel, 1987; para los misioneros y antropólogos en el Miriti-Parana, ver Oostra, 1991; y para el rol del dinero y el trueque aguas arriba en el Mirití-Paraná, ver Rosas Riaño, 2007.

102 ver Ortiz Gómez, 2011; Santos-Granero, 2009.

103 Eriksen, 2011, 48.

104 sobre etnobotánica de Palmas en la Amazonia colombiana, ver Mesa Castellanos, 2011.

105 para los curripacos del río Isana, ver Journet, 1980; y para el genocidio de los witoto, ver Burgos, 2003. 
Artigo original

Hegemonia - Revista Eletrônica de Relações Internacionais do Centro Universitário Unieuro

ISSN: $1809-1261$

UNIEURO, Brasília, número Especial, 2016, pp. 121-174.

los indios en blancos), ${ }^{106}$ y casi un siglo más tarde el de la misionera evangélica Sophie Müller que a fines de 1940 innovó con sus juegos de dramatización de personajes bíblicos o teatralización de la etnicidad, y con su sistema de iglesias dirigidas por pastores indígenas y consejos de ancianos. ${ }^{107}$ Luego, remontando aún más el Alto río Negro, en la frontera brasilera con Venezuela, se alcanzan las localidades de Cuarinuma, Brujas, Tabaquén, Tonina, y Puerto Inírida (95 msnm y 40 mil h.).

Más abajo de Sao Gabriel da Cachoeira, en el Bajo río Negro, se confluye con la desembocadura perpendicular del sub-afluente rio Branco, que procede de los ríos que fluyen del macizo o escudo guyanés (entre ellos el río Tacutú y su sub-afluente el río Ireng que conectan con el Mar de las Antillas), donde remontando su margen derecho se alcanza la capital del estado brasileño de Roraima, Bandeira de Boa Vista (284.313 h.), y más arriba a unos treinta km. la antigua fortaleza de São Joaquim (fundada por el Ministro Pombal y reforzada después de la Guerra con Paraguay), y más arriba aún la reserva indígena Raposa/Serra do Sol, territorios arroceros y ricos en minerales como el nióbio, y hogar de los makuxí (caribe), wapixana (arawak), ingarikó (caribe), taurepang (pemón) y patamona (caribe); y las localidades de Aru, Içana, y Forte de São José de Marabitanas (que fue prisión política en tiempos de la Revolución Federalista del siglo XIX), territorios fronterizos que dieron lugar a la Cuestión de Pirará (1904), un contencioso entre el Brasil y la Guayana Británica resuelto por el arbitraje del Rey de Italia Víctor Manuel III. ${ }^{108}$

\footnotetext{
106 ver PinedaCamacho, 1988.

107 para la controvertida carrera de Sofía Müller, ver Rausch, 2013.

108 donde el abogado defensor del Brasil fue Joaquim Nabuco con una alegato en dieciocho volúmenes escrito en francés.
} 
Artigo original

Hegemonia - Revista Eletrônica de Relações Internacionais do Centro

Universitário Unieuro

ISSN : $1809-1261$

UNIEURO, Brasília, número Especial, 2016, pp. 121-174.

Estos territorios habían sido recorridos a comienzos del siglo XIX por el taxidermista inglés Charles Waterton, el mismo que habría llegado a inspirar a Darwin. ${ }^{109}$

En la desembocadura con el Amazonas, el Bajo río Negro da lugar a la ciudad y puerto de Manaos (84 msnm, km 1650, entre la creciente máxima y mínima un rango de $7.8 \mathrm{~m}$., y dos millones de h.). Y más abajo de Manaos, en dirección al oriental estado de Amapá, y su capital Macapá, 110 en el margen septentrional del Amazonas, desembocan de occidente a oriente perpendicular y sucesivamente, procedentes del macizo Guayanés, los cortos ríos Urubú (donde en 1660 la Orden Mercedaria fundó la Misión Saracá, y en 1690 el padre Samuel Fritz registró en su Diario la evidencia de un tremendo terremoto), Uatumá (Central hidroeléctrica de Balbina -con gran peligro de un nuevo terremoto-- y localidades de Cachoeira Balbina y Cachoeira Morena), Nhamundá, Jarí (localidad de Cachoeira de Santo Antonio), y Trombetas (nace en la serra do Acaraí que limita con Surinam. En sus márgenes falleció el explorador francés Henri Coudreau), y el puerto de Óbidos (300 mts de profundidad y 50.317 h. $).{ }^{111}$ En este tercer tramo se alcanza en sus puertos una totalidad de medio millón de habitantes.

109 para un análisis del estado de Roraima, limítrofe con Venezuela y la Guyana Británica, ver Foresta, 1992; y para la etnogeografía y el uso de los recursos entre los Yanomami de la región entre los estados de Roraima y Amazonas, ver Bruce y Le Tourneau, 2007.

110 Donde se celebró el VII Foro Social Pan-Amazónico.

111 Perea Borda, 1998, 109. En este puerto fue a pique el Barco Motor Sobral Santos 2 en 1985 muriendo 250 personas, cuando cumplía el derrotero Santarém-Manaus. En los parajes del estado de Amapá habitaban indios de la etnía Aguaraca, que tocaban instrumentos de viento o flautas confeccionadas con canillas humanas producto de 
Artigo original

Hegemonia - Revista Eletrônica de Relações Internacionais do Centro Universitário Unieuro

ISSN: $1809-1261$

UNIEURO, Brasília, número Especial, 2016, pp. 121-174.

\section{A-IV.-Cuarto tramo o corredor septentrional brasilero y caboclo (Mapa V).}

Dejando el margen (o vertiente) izquierdo o septentrional del Río Amazonas (verdadera frontera con la Isla Guayana y no centro de un supuesto espacio amazónico), encaramos ahora el cuarto tramo del circuito amazónico-platino, consistente en la margen derecha o meridional del Amazonas, caracterizada por la combinación de siete (7) grandes afluentes de llanura procedentes de los macizos charqueño y central brasilero-platino (son ríos largos, lentos, meándricos y sembrados de saltos y corredeiras), de los cuales cuatro son hidrovías. A diferencia de la vertiente septentrional, estos ríos desembocan en el Amazonas en forma cuasi-perpendicular, y en una red de drenajes paralelos (que en épocas de crecida pueden llegar a cambiar su curso). ${ }^{112}$ Estos siete (7) ríos los numeramos y ordenamos de occidente a oriente, donde el Amazonas al bajar hacia el Atlántico viene capturando dichos ríos y cortando el relieve que separa cada uno de ellos, el Javary (Yavarí en Perú), el Juruá, el Purús, el Madeira, el Tapajós, el Xingú, y finalmente el Tocantins, casi en la desembocadura del Amazonas, donde el tráfico de los tres primeros son los que tendrán más interés en navegar río arriba del Madeira. Entre el Javary y el Juruá desembocan en el Amazonas dos ríos más cortos, que son el Tonantins (no confundir con el Tocantins) y el Coarí (donde tuvo su sede una Misión de los Carmelitas portugueses). ${ }^{113}$

actos antropofágicos, como los que sufrieran en el Cabo do Norte los padres Bernardo Gomes y Antonio Pereira en 1688. Estos padres fueron sacrificados en represalia por haber cremado los restos mortuorios de un chamán, ver Tombini Wittmann, 2011.

112 ver Dourojeanni, 2010.

${ }^{113}$ Ver Oliveira, 2006. 
Artigo original

Hegemonia - Revista Eletrônica de Relações Internacionais do Centro Universitário Unieuro

ISSN: $1809-1261$

UNIEURO, Brasília, número Especial, 2016, pp. 121-174.

En este cuarto tramo del circuito amazónico-platino, la población está muy mestizada y las ciudades están jerárquicamente clasificadas por los sociólogos en macro-polos, meso-polos, y micro-polos. ${ }^{114}$ Entre esos destinos portuarios, primero fue Tabatinga (60 msnm y 40.000 h.), sede del Servicio de Protección Indígena (SPI, fundado en 1911) en la triple frontera con Perú y Colombia y estado brasilero de Amazonas, a la margen izquierda del río Amazonas, y a una duración y distancia fluvial con Manaos de un millar de km., o tres (3) días de navegación río abajo, a razón de $14 \mathrm{~km}$. cada hora; y de siete (7) días rio arriba a razón de 6 $\mathrm{km}$. cada hora. Esta triple frontera es semejante a la triple frontera entre Ecuador-Colombia-Perú en el codo del Güepí; a la triple frontera entre Paraguay, Brasil y Argentina, en las ciudades de Foz do Iguaçu en Brasil y Ciudad del Este en Paraguay; a la triple frontera entre Brasil, Uruguay y Argentina en las ciudades de Monte Caseros, Bella Unión y Barra do Quaraí; y a la triple frontera que se registra en Corumbá, entre Bolivia, Brasil y Paraguay.

El primer afluente, bajando por el Amazonas, es el río Javary, en la frontera con Perú, estado de Amazonas, cuyas aguas proceden del macizo cordillerano. En este afluente se alcanza las localidades de Atalaia do Norte (13.682 h.), Belém do Solimoes (aldea indígena tikuna), y Benjamin Constant (60 msnm, km 3128, pendiente media de 1.25 cm/km, y 26.191 h.), sede del Museo Tikuna (Centro de Documentacao e Pesquisa de Alto Solimoes; ${ }^{115}$ ubicado frente a Tabatinga, donde suma un

\footnotetext{
114 ver Guedes, Costa y Brondizo, 2009; para el mestizaje en las tierras bajas de Sudamérica, ver Bauer, 2014.

115 Perea Borda, 1998, 104-105. Para el Museo Maguta de la Tribu Tikuna, ver Carvalho, 2006.
} 
Artigo original

Hegemonia - Revista Eletrônica de Relações Internacionais do Centro Universitário Unieuro

ISSN: $1809-1261$

UNIEURO, Brasília, número Especial, 2016, pp. 121-174.

total de 40.000 h., y entre ellos el grupo étnico yagua de la familia lingüística peba. ${ }^{116} \mathrm{El}$ etnólogo germano-brasileño Curt Unkel Nimuendajú con sus Informes y sus estudios sobre los tikuna y su muerte trágica (envenenado con un café) fue el primero en acuñar la noción de la Tierra $\sin \mathrm{Mal}$, en un trabajo publicado en alemán en 1914, y recién traducido al castellano por una editorial de San Pablo en $1944 .{ }^{117}$ Se sospecha que los patrones caucheros indignados por la atracción carismática que ejercía sobre los tikuna fueron los que lo envenenaron. ${ }^{118}$ Continuando el descenso por el río Amazonas (Solimoes para Brasil) damos con la aldea de Sao Paulo de Olivença (58 msnm y 27.000 h., transformada en vila en 1759), aguas arriba de la boca del río Jandiatuba, y con la población de Amaturá (58 msnm), para recalar en San Antonio de Içà frente mismo a la desembocadura del Río Içà/Putumayo. Luego más abajo damos con la desembocadura del río Tonantins, con las poblaciones de Jutaí y Fonte Boa, y aún más abajo con la boca del río Coarí.

El segundo afluente, bajando por el Amazonas, es el río Juruá o Yuruá (río de color blanco, poblado por la etnía aisuari de lengua tupí, asidua comerciante con las tribus arawaks del río Vaupés, no confundir con el río Jaurú afluente del Alto Paraguay), y cuyas aguas proceden del macizo cordillerano. En este afluente se alcanza las ciudades de Parintins (27 msnm y 108.250 h.), y Manacapuru (34 msnm y 100.656 h.), poblaciones predominantemente caboclas o curibocas de extracción sertanista, que en su origen estuvo poblado por indios muras hoy extinguidos, verdaderos

\footnotetext{
116 ver Chaumeil, 1983; Chuecas Cabrera, 1996.

117 ver Villar y Combés, 2013, 203.

118 ver Leonardi, 2001; Pacheco de Oliveira, 2006; y Faulhaber, 2010.
} 
Artigo original

Hegemonia - Revista Eletrônica de Relações Internacionais do Centro Universitário Unieuro

ISSN: $1809-1261$

UNIEURO, Brasília, número Especial, 2016, pp. 121-174.

gitanos acuáticos, sumando en la cuenca un total de 370.000 h., ${ }^{119}$ los puertos de Carauarí (27.645 h.), Ipixuna (22.867 h.), Guajará (14.037 h.), y más arriba Eirunepé, antigua João Pessoa y anteriormente Vila de São Felipe do Rio Juruá (75 msnm y 33.580 h., fundada en 1894), sumando en esta cuenca del estado de Amazonas la totalidad de 106.478 h. Y en el Alto Juruá topamos con las bocas de los sub-afluentes Breu y Tarauacá, y remontando dichos subafluentes llegamos a las poblaciones de Vila Martins y Envira (198 msnm y 17.431 h.).

Como decíamos antes, la población de este cuarto tramo amazónico, con excepción de la correspondiente a los afluentes Xingú y Tapajós, está intensamente mestizada. Como el siringueiro nordestino caboclo que pobló esta cuenca venía soltero se casaba con mujeres indígenas de la tribu Kulinaã, de habla pano, y conocidos entre los demás indios por nunca haber sido reducidos a misiones, ser grandes cazadores, y tener caras redondas y ojos extremadamente largos, con lo que se producía un proceso de mongrolizacion con conflictos de todo tipo debido a su estereotipado carácter faldero y mujeriego. ${ }^{120}$ Más arriba en el Alto Juruá se alcanza Cruzeiro do Sul (182 msnm, $2460 \mathrm{~km}$ de la boca del río, y 79.819 h. ), Marechal Thaumaturgo (2800 km de la boca, 13.061 h., poseía 4 metros de profundidad), Rodrigues Alves (12.428 h.) y Porto Walter (204 msnm y 8.170 h.), estado de Acre, donde suma un total de 113.478h. En el territorio del Alto Juruá, en la frontera con Perú, se encuentran las denominadas "reservas extractivas", fundadas por Chico Mendes, el asesinado líder ambientalista víctima de los traficantes de

\footnotetext{
119 ver Parker, 1985; y Amoroso, 1992.

120 ver Fleck, 2007.
} 
Artigo original

Hegemonia - Revista Eletrônica de Relações Internacionais do Centro Universitário Unieuro

ISSN: $1809-1261$

UNIEURO, Brasília, número Especial, 2016, pp. 121-174.

tierras o grileiros. ${ }^{121} \mathrm{Y}$ entre su población se encuentran los grupos étnicos Yawanawa en el Alto Río Gregorio cuyos chamanes practicaban ritos de iniciación y poseían poderes terapéuticos; ${ }^{122}$ los Katukina (del río Biá, afluente del río Jutaí, y éste del Amazonas), los Yaminahua tenidos por algunos como "salvajes"; 123 los Kashinahua también de la familia lingüística pano y de cosmología transformista, que creía en la metamorfosis de humanos en animales; ${ }^{124}$ y los Manchineri de lengua piro. ${ }^{125}$ Estos ríos funcionaban como arterias comunicantes con el hinterland amazónico facilitando el comercio a larga distancia. ${ }^{126}$

Luego más abajo en el Amazonas se encuentra la ciudad Tracatuva de Tefé (62.662 h.), frente a la desembocadura del Caquetá/Japurá, pasando la boca del río Juruá y en el estuario del rio Tefé, donde habían habitado los aisuari (etnía tupí que comerciaba con los kuripaco del río Negro), ${ }^{127}$ y luego la ciudad de Coarí (40 msnm y 82209 h.), a orillas del río Urucú (afluente del Coarí, que desemboca en el Amazonas). Más abajo del río Amazonas, damos con el tercer afluente, el río Purús (río de aguas blancas $y$ en $1.300 \mathrm{~km}$ su profundidad no es nunca inferior a $15 \mathrm{~m}$.), habitado por

${ }^{121}$ ver Jiménez, 2008; y Ribeiro, 2006, 312-314.

122 ver Pérez-Gil, 2001.

123 ver Townsley, 1993; Calavia Sáez, 1995.

124 para los Pano, ver Keifenheim, 1992; y para las nociones de tiempo social y espacio social entre los Kashinahua, ver Kensinger, 1977.

125 ver Gray, 1997), y para los Asháninka de la familia lingüística arawak (ver Rojas Zolezzi, 2014; y Adelaar, 2000.

126 Eriksen, 2011, 74.

127 ver Eriksen, 2011, 48. 
Artigo original

Hegemonia - Revista Eletrônica de Relações Internacionais do Centro Universitário Unieuro

ISSN: $1809-1261$

UNIEURO, Brasília, número Especial, 2016, pp. 121-174.

los apuriná (un activo eslabón entre los kuripaco del Vaupés y los baures de Moxos), que habían sido estudiados por el geógrafo inglés William Chandless. ${ }^{128}$ Por el río Purús se llega en el estado de Amazonas a Canutama (km 1116, 14944 h.), Lábrea (km 1341, 42439 h.), y en la confluencia con el afluente río Acre, con la localidad de Boca de Acre (km 2187).

Y en la confluencia del río Purús con el río Iaco llegamos a Sena Madureira (150 msnm, km 2450 y 34.230 h.), y más arriba a Manoel Urbano (185 msnm, km 2660 y 7.843 h.), y Santa Rosa do Purús (265 msnm y 3.948 h.), que linda a $350 \mathrm{~km}$ de la frontera con Perú. Remontando su subafluente el río Acre se llega a las ciudades de Assis Brasil (239 msnm y 5.351h.) y Brasiléia (245 msnm, km 640 y 18.056 h.), y a los subafluentes Antimari y Xumari. Y remontando el sub-afluente río Branco se alcanza la ciudad de Rio Branco (153 msnm, km 286 y 363.928 h.), próxima a la frontera con Bolivia. ${ }^{129}$ Más luego en la confluencia del Amazonas con el río Negro tropezamos en la margen izquierda con la ciudad de Manaos (a 1650 km. de Belém do Pará con calados de 8 a 11m., y 1.982 .179 h.), totalizando en el tercer afluente la suma de 2.154.000 h..

Más abajo aún en el Amazonas, el cuarto afluente es la cuenca del río Madeira, la más despoblada de todas las cuencas meridionales, y cuyas aguas con mil km. navegables proceden de los macizos cordilleranos (Madre de Dios) y central platino (Guaporé) y de las planicies sabánicas

\footnotetext{
128 quien dejó un fascinante informe publicado por la Royal Society, ver Gow, 2006.

129 sobre los procesos de nacionalización y tribalización en la amazonía sud-occidental y el rol de las canciones purús, ver el muy sugestivo trabajo de Gow, 2006.
} 
Artigo original

Hegemonia - Revista Eletrônica de Relações Internacionais do Centro Universitário Unieuro

ISSN: $1809-1261$

UNIEURO, Brasília, número Especial, 2016, pp. 121-174.

de los Llanos de Moxos (Beni) y de la Chiquitanía o Santa Cruz de la Sierra (Mamoré). En este afluente confrontamos en la región del Bajo Madeira, primero con Santa Maria dos Marmelos (50 msnm y 133 h.), y luego con la ciudad de Itacoatiara (100 msnm y 100.890 h.). Y remontando el Madeira llegamos a las localidades de Nova Olinda do Norte (37 msnm, km 78 y 34498 h.), Borba (km 166), Novo Aripuana (km 311 y 21 389 h.), Manicoré ( 75 msnm, km 458 y 48.252 h.), Humaitá (90 msnm, km 816, y 50.230 h.), Calama (km 882), la desembocadura del Ji-Paraná, y finalmente Porto Velho (83 msnm, con un declive de $1.7 \mathrm{~cm} / \mathrm{km}$, 369.259 h.), la capital de Rondonia, ubicada a tres días de navegación de Manaos, y después de haber navegado por el Madeira desde su boca 1060 $\mathrm{km}$, a razón de $13 \mathrm{~km}$. cada hora, se totalizaron en el cuarto afluente 150.000 h.. ${ }^{130}$ En la cuenca del río Ji-Paraná, se alcanza la ciudad de JiParaná (103.256 h.) a orillas del río Urupá, afluente del Ji-Paraná. En la región del Alto Madeira es donde se presume que en tiempos inmemoriales civilizaciones ancestrales domesticaron la mandioca y el pejibaye. ${ }^{131}$ Remontando el río Marmelos se alcanzan dos de sus principales afluentes, el río Branco y el río Maici. En su curso alto el Marmelos recibe el río Branco y luego bordea el territorio indígena de Pirahã, remanente de la familia étnica Mura investigada por Everett (2014). Esta etnía se caracteriza por su excepcionalidad pues carece de expresión artística, de ficciones y de mitos, no tiene capacidad de abstracción al extremo de no poder contar ni tener palabras para los

\footnotetext{
130 Perea Borda, 1998, 113.

131 ver Hornborg, 2005, 611.
} 
Artigo original

Hegemonia - Revista Eletrônica de Relações Internacionais do Centro Universitário Unieuro

ISSN: $1809-1261$

UNIEURO, Brasília, número Especial, 2016, pp. 121-174.

colores y la orientación espacial de izquierda y derecha, y posee una lengua única y desconocida magistralmente estudiada por Everett (2014).

Aún más abajo del río Amazonas, el quinto afluente es el río Tapajós (río de color verde azulado, que lleva un mayor contenido de nutrientes, tiene un declive de $12 \mathrm{~cm} / \mathrm{km}$ ) que hace de frontera natural entre los estados de Amazonas y Pará, cuyas aguas proceden del macizo central platino (Mato Grosso), y que fue explorado en 1826 por el barón ruso Georg Heinrich von Langsdorff. Las exploraciones en el Tapajós continuaron casi un siglo más tarde, en 1913, por el inglés Arnold Savage-Landor, y en la década del sesenta del siglo $X X$ fue el célebre escenario de las investigaciones del belga Claude Levi-Strauss, inmortalmente registrado en su obra Tristes Trópicos. Su extensión desde Santarém a Cachoeira Rasteira alcanza los mil km. ${ }^{132}$ Se alcanza primero en el estado de Pará, en la confluencia con el río Amazonas y en la margen derecha del Tapajós, la ciudad de Santarém (51 msnm, entre la creciente máxima y mínima un rango de 6.7 m., y 274.012 h. ), que había sido originalmente en el siglo XVII sede de la aldea o Misión de Tapajós donde desplegó su apostolado jesuítico con metodología musical el padre Antonio Vieira, y luego la Barraca de Alfredo Lopes y de Paraiso, en el estado de Amazonas. ${ }^{133}$ Remontando el Tapajós, en la región del Bajo Tapajós, damos con las localidades de Puerto Crateiro, Jacareacanga (41.487 h.), luego Belterra (75 msnm y 16.808 h.), y Aveiro (15.000 h.), el área

132 Ver Da Silva Alves, 2008.

133 Ver Andrade Ribeiro de Oliveira y Brazón Hernández, 2001. Para los jesuitas y el adoctrinamiento de los indígenas en la América portuguesa de los siglos XVI e XVII, ver Brust, 2007. Y sobre el rol de la música en el apostolado jesuítico portugués (Antonio Vieira S.J.), ver Tombini Wittmann, 2011 
Artigo original

Hegemonia - Revista Eletrônica de Relações Internacionais do Centro Universitário Unieuro

ISSN: $1809-1261$

UNIEURO, Brasília, número Especial, 2016, pp. 121-174.

tapajónica que Henry Ford pobló y donde construyó en 1927 la utópica y fracasada ciudad de Fordlandia (entre Belterra y Aveira hay 150 km que se cubren en un viaje fluvial de un par de horas), ${ }^{134}$ Itaituba (188 msnm y 124.865 h.), y Sao Luis do Tapajós (cachoeiras y usina hidroeléctrica), hasta donde es navegable cubriendo un tramo de $345 \mathrm{~km}$. desde Santarém, totalizándose en el quinto afluente la cantidad de 470.000 h.. Remontando el Alto Tapajós, se llega a los territorios de grupos étnicos como los Munduruku (responsables de la derrota de los indios Mura del río Madeira) y al sub-afluente río Juruena, que atraviesa las localidades de Barraçao do Barreto y Visita, y remontando el Juruena se alcanza el sub-afluente Teles Pires (o río Manoel), que baña las localidades de Barra de São Manuel, Pereriniha y San João de Paraná. Cerca del Teles Pires en el estado de Mato Grosso do Norte se aproxima al Alto Paraguay, río que fluye hacia el sur y que pertenece a la cuenca platina.

Y aún más abajo del Amazonas el sexto afluente es el río Xingú, en el estado de Pará (apodado 'el río de aguas claras', intermedio entre blancas y negras), con múltiples sub-afluentes en ambos márgenes, y cuyas aguas proceden de la Serra do Roncador en el macizo central platino (Mato Grosso). En la región del Bajo Xingú, o corredor Xinguara, se llega río arriba a las ciudades de Altamira (109 msnm y 106.768 h.), Senador José Porfirio (12.998 h.), Porto de Moz (28.091 h.), Vitória do Xingú (13.480 h.), y Sao Félix do Xingú (99.905 h., mayoritariamente caboclos. ${ }^{135}$ Donde hoy está la ciudad de Santarém estuvo en el siglo XVII

\footnotetext{
134 para el auge y caída de la olvidada ciudad selvática de Henry Ford, ver Grandin, 2009.

135 ver Parker, 1985.
} 
Artigo original

Hegemonia - Revista Eletrônica de Relações Internacionais do Centro

Universitário Unieuro

ISSN: $1809-1261$

UNIEURO, Brasília, número Especial, 2016, pp. 121-174.

la Misión de Tapajós dirigida por el jesuita portugués Antonio Vieira S.J.; en la Misión de Maranhao estuvo a fines del siglo XVII el luxemburgués Joao Felipe Bittendorff S.J.; y en Altamira estuvo el jesuita austríaco Roque Hunderfund S.J., quien en 1750 creó la Misión Tavaquara, cinco años antes de ser expulsados por el Ministro Pombal y por su mediohermano el Gobernador de Grao Pará Francisco de Xavier Mendonça Furtado. ${ }^{136}$ Un siglo más tarde, la misma región fue visitada por el Príncipe Adalbert de Prusia (hijo primogénito del Kaiser Guillermo II). A orillas del río Castanhal, se alcanza la ciudad de Castanhal (141 msnm y 186.895 h.), y a orillas del sub-afluente Maratauíra, cerca de la boca del Tapajós, la ciudad de Abaetetuba (42 msnm y 350.000h.). Y más arriba, en la región del Alto Xingú, estado de Mato Grosso do Norte, poblado con políticas de frontera corporativa, ${ }^{137}$ se alcanza la localidad de Sao José do Xingú (6.356 h.), la ciudad de Novo Acordo (3.323 h.), estado de Tocantins, y numerosas reservas o resguardos, conocidos en Brasil como parques o tierras indígenas, de grupos étnico-lingüísticos (Apnajé; Xambioá; Xerente; Kráô; Kraô-canela; Karajá; Javaé; Pankararu; AváCanoeiro, así como los Asurini de habla guaraní, y los Suyá de habla Jé), sumando en la totalidad del Xingú o sexto afluente 269.717 h. ${ }^{138}$

En estos grupos étnicos, por estar lejos de la frontera con Colombia, Perú o Bolivia su identidad étnica es más fuerte que la identidad nacional. Por

\footnotetext{
136 Para el ocaso del poder jesuítico en la Amazônia, ver Ferreira Glielmo, 2007. Para el poder temporal en las aldeas de indios o aldeamentos y los conflictos entre los jesuitas portugueses y la corona de Portugal (1751-1759), ver Couto, 2007. Para el rol del jesuita Bittendorff, ver Arenz, 2010 y 2014; y para el adoctrinamiento de los indígenas en la amazonia portuguesa del siglo XVII, ver Brust, 2007 y Pressler, 2012.

137 Browder \& Godfrey, 1997.

138 para los procesos de desterritorialización y reterritorialización de las sociedades indígenas en el área xinguana, ver Deus, Miranda Rodrigues y Deus Barbosa, 2010.
} 
Artigo original

Hegemonia - Revista Eletrônica de Relações Internacionais do Centro Universitário Unieuro

ISSN: $1809-1261$

UNIEURO, Brasília, número Especial, 2016, pp. 121-174.

el contrario, cerca de las fronteras de Perú, Colombia o Bolivia la identidad étnica es más débil que la identidad nacional. ${ }^{139}$ De las numerosas reservas mencionadas, el etnólogo alemán Karl von den Steinen expedicionó en dos oportunidades al Xingú, en 1884 y en 1887 (fue quien descubrió el origen Caribe de la lengua Bakaïrí), y Hermann Meyer durante 1895-1897, y de nuevo en 1899. A mediados del siglo XX durante el gobierno de Vargas establecieron en el río Xingú su territorio filantrópico los hermanos Villas Boas, a partir primero de la expedición pacificadora Roncador-Xingú y luego de la expedición Xingú-Tapajós. ${ }^{140}$ Estas reservas tienen $3.600 \mathrm{~h}$. distribuídas en catorce (14) grupos étnicolingüísticos diferentes, entre las cuales se destacan los pertenecientes a los siguientes tres troncos lingüísticos, el Tupí-Guaraní (Kamaiurá, Juruna; ${ }^{141}$ el Arauak (Suyá), y el Karib. ${ }^{142}$

Y bajando el río Amazonas hasta su boca, en el estado de Pará (7.588.078 h.), el séptimo afluente es el río Tocantins (no confundir con el Tonantins, que está mucho más arriba), donde en su confluencia con el río Itacaiúnas se alcanza la ciudad de Marabá (84 msnm y 233.462 h., a 547 km. de Belém do Pará), próxima al grupo étnico Kayapó-Xikrin enemigo de los Xingú (del grupo lingüístico macro-yé). ${ }^{143}$ Este grupo étnico era famoso

\footnotetext{
139 para las nuevas posibilidades de cooperativas indígenas en el Xingú, ver Burke, 2012; y para el shamanismo en Parakanã, Sao Félix do Xingú, ver Fausto, 2015.

140 Shkrada Resk, 2010.

141 ver Carod-Artal, y Vázquez-Cabrera, 2001.

142 Kalapalo, ver Mackey, 1993.

143 ver Eriksen, 2011, 89.
} 
Artigo original

Hegemonia - Revista Eletrônica de Relações Internacionais do Centro Universitário Unieuro

ISSN: $1809-1261$

UNIEURO, Brasília, número Especial, 2016, pp. 121-174.

por su sistema ecológico que crea bosques y enriquece matorrales; ${ }^{144}$ y estaba muy próximo a la localidad de Eldorado dos Carajás (célebre por los conflictos entre los karajás y los xavantes y por la matanza de los Sin tierra). Remontando el río Tocantins (de 715 km de largo), que es el séptimo y último afluente de la vertiente meridional del Amazonas, en el estado de Tocantins, se alcanza la boca del Araguaia (su origen está en la Serra do Carajás), cuyas principales ciudades son Araguaína (227 msnm y 153.350 h.), Gurupi (75.287 h.), la capital Palmas (230 msnm y 208.165 h.), Paraíso do Tocantins (45.669 h.), Porto Nacional (237 msnm y 49.143 h.), y Taquarussu do Porto (4.739 h.), totalizando en el séptimo afluente $787.000 \mathrm{~h} .$. Y remontando el río Araguaia (de $1700 \mathrm{~km}$ de largo), se topa con la boca del río Das Garças (donde en la década del 20 se descubre en su lecho diamantes) y la del río Das Mortes (de $425 \mathrm{~km}$ de largo), célebre por la batalla entre los bandeirantes y los xavantes (de la familia lingüística macro-yé o gé, parientes de los charrúas, de la Banda Oriental del río Uruguay, y cuyos orígenes remotos residirian en el MatoGrosso), el mismo lugar donde más tarde desapareció el mundialmente famoso explorador inglés Percy Fawcett, víctima de la práctica antropofágica de los indios Xavantes.

No obstante la intensidad de la migración y el mestizaje internos, los conflictos por la tenencia rural se acentuaron, en especial en la región Araguaia-Tocantins. ${ }^{145}$ En ese sentido, la migración interna estaba

144 para las investigaciones etnobiológicas sobre los Kayapó, ver Posey, 1992; López Garcés, y de Robert, 2001; y Pereira de Lima, 2001.

145 ver Kotscho, 1981; y Walker, 2011; para el caso de los indios Krahó, ver Zahluth Bastos, 2009. 
Artigo original

Hegemonia - Revista Eletrônica de Relações Internacionais do Centro Universitário Unieuro

ISSN: $1809-1261$

UNIEURO, Brasília, número Especial, 2016, pp. 121-174.

garantizada por la existencia de ferias y mercados que comercializaban plantas y hongos medicinales como en Sao Luis (1.039.610 h.) y otras ciudades: Imperatriz (232.560 h.), Timon (163.342 h.), Caxias (155.129 h.), Açailândia (240 msnm y 101.130 h.), Codó (118.072 h.), Santa Inês (82.680 h.), Bacabal (38 msnm y 101.738 h.), y Balsas (89.126 h.). ${ }^{146}$ En la boca del Amazonas se alcanza la ciudad de Belém (10 msnm y 2.146 .000 h.). Y en la confluencia del río Araguari con la boca del Amazonas, pero en su margen izquierda o septentrional, se alcanza el estado de Amapá (698.602 h.), su capital Macapá (12 msnm y 366.484 h.), la ciudad de Santana y el grupo étnico Wajapi (101.864 h.), cuyos ríos y afluentes proceden del macizo Guayanés.

En el caso del cuarto tramo o corredor brasilero septentrional, las diferencias estadísticas son abrumadoras. Mientras en el lado brasilero de la cuenca del río Javarí, en el cuarto corredor del circuito amazónicoplatino, la población es de 400.000 h., el total de población del estado de Amazonas descontado Manaos es de 1.500 .000 h., o cuatro veces superior. Y mientras en la ribera del río Acre (afluente del Purús) la población es de 42.200 h., la del estado de Acre (Brasil), sin contar la de su capital Rio Branco (153 msnm, y 363.928 h.) donde existe un afamado Museo del Caucho--no confundir con el río del estado de Roraima que procede del macizo Guayanés- es ocho veces superior, de un total de 368.865 h. Esta diferencia obedecería a que no se computaron otras ciudades muy pobladas como Tarauacá (30.711 h.), Sena Madureira (33.614 h.) y Brasiléia (18.056 h.)..

146 ver Linhares, 2014. 
Artigo original

Hegemonia - Revista Eletrônica de Relações Internacionais do Centro Universitário Unieuro

ISSN: $1809-1261$

UNIEURO, Brasília, número Especial, 2016, pp. 121-174.

Por último, en este cuarto tramo, mientras la totalidad de las ciudades a orillas de ríos da una suma de 3.400 .000 h., la población del estado de Pará la duplica (7.600.000 h.). Y en el estado de Mato Grosso, mientras en la ribera del río Xingú, la población es de 269.717 h., y la del río JiParaná es de 103.256 h., la del estado la quintuplica, pues es de un total de 2.000.000 de h. La ostensible diferencia obedece a que estos estados se hallan sumamente urbanizados pues poseen numerosas localidades situadas en serranías dispersas y alejadas de los ríos. ${ }^{147}$ También en este tramo, se registra la presencia de poblaciones afrobrasileñas, con sus propias narrativas y religiones. ${ }^{148}$

\section{A-V.-Quinto corredor brasilero meridional o frontera populista (Mapa VI)}

Dejando las localidades brasileras del cuarto tramo, remontando primero el río Madeira y luego el Guaporé, conectando por un corto istmo con los ríos Aguapey y Jaurú o Yaurú (afluentes occidentales del Alto Paraguay), se alcanza el Alto Paraguay, jurisdicción de Mato Grosso del Norte, cuyas aguas proceden en su totalidad del macizo central platino, no recibiendo aguas algunas del macizo cordillerano andino.

Ascendiendo por la cuenca del río Madeira, estado de Rondonia, se alcanza su capital Porto-Velho (83 msnm y 373.917 h.), y luego de recorrer río arriba $350 \mathrm{~km}$. plagados de saltos y corredeiras y remontar

147 para la jerarquía de las áreas urbanas en la amazonía brasilera, ver Sathler, et. al., 2010; y Guedes, Costa y Brondízio, 2009.

148 para audiovisuales con las narrativas afro-brasileñas del Pará, ver Cordovil, 2012. 
Artigo original

Hegemonia - Revista Eletrônica de Relações Internacionais do Centro Universitário Unieuro

ISSN: $1809-1261$

UNIEURO, Brasília, número Especial, 2016, pp. 121-174.

una caída de 60 mts., recibe por el margen derecho el afluente Ribeirao. Y más arriba, en la confluencia del Madeira con el Bajo-Mamoré, en la frontera con Bolivia, se llega a la ciudad de Guajará-Mirim (128 msnm y 41.467 h.), donde tiene su inicio una desactivada vía férrea de $300 \mathrm{~km}$. conocida como Ferrovia do Diabo o Trem Fantasma, cuyo nombre obedece a la enorme cantidad de víctimas que llevó su construcción a comienzos del siglo XIX. ${ }^{149}$

Y luego, subiendo por el Bajo Mamoré hasta encontrarse con el Guaporé, su extensión navegable desde Guajará-Mirim hasta Vila Bela da Santisima Trindade alcanza los $750 \mathrm{~km}$. (o 4 días de navegación río arriba en lancha), y luego tras un corto trecho terrestre y navegando río abajo por el Jaurú se llega a Cáceres, que son otros $270 \mathrm{~km}$. (o un día de navegación). ${ }^{150}$ Más arriba, en la margen derecha del Guaporé, damos con el puerto Versalles, y más arriba aún proseguimos con sus afluentes que nacen en los contrafuertes de la Chapada dos Parecis. ${ }^{151}$ En la margen izquierda del Guaporé que los bolivianos denominan Itenéz, se topa en territorio boliviano con las poblaciones de Cafetal (Puerto Valiténez) y Remanso, y más arriba el Puerto Villazón (3,8 msnm y 313 h.) donde recientemente hubo bíblicas inundaciones que se llevaron más de medio centenar de muertos.

149 ver Rodrigues Ferreira, 1960; Foot Hardman, 1988; Ribeiro, 2006, 173-176; y Cooper, 2011.

150 Para el comercio y las rutas fluviales en la sociedad guaporeana colonial, ver Domingues Teixeira, 1998.

${ }^{151}$ Ver Perea Borda, 1998, 131 y mapa 3.2-4. 
Artigo original

Hegemonia - Revista Eletrônica de Relações Internacionais do Centro Universitário Unieuro

ISSN: $1809-1261$

UNIEURO, Brasília, número Especial, 2016, pp. 121-174.

En el resguardo o 'Tierra Indígena (TI) Sagarana viven los Wari o Huari (de la familia lingüística chapakura), asentados alrededor de siete (7) puestos de la Funai (Fundación Nacional del Indio) con sede en 'GuajaráMirim', en Rondonia. ${ }^{152}$ Mientras en la ribera del río Guaporé, en el quinto tramo o corredor brasilero meridional, la población es de 138.825 h., la del estado de Rondonia lo decuplica, pues es de un total de $1.560 .500 \mathrm{~h}$. Esta diferencia obedecería a que no hemos computado ciudades no ribereñas como Cacoal ( 261 msnm y 90,556 h.), Jarú (52.005 h.), Vilhena (386 msnm y 68.405 h.) y Presidente Medici (22 783 h.).

Remontando ahora el río Guaporé (cuya margen derecha tiene la barranca más alta), se alcanzan en Rondonia los Fuertes de Nossa Senhora da Conceição/Bragança, y Principe da Beira (10.000 h., que dista de la ciudad de Guajará Mirim 375 km, por via fluvial), donde aún subsiste la famosa fortaleza, y muy próxima al yacimiento arqueológico pre-incaico Ciudad Laberinto, y más arriba las localidades de Costa Marques (140 msnm y 13.700 h.), Pimenteiras do Oeste (185 msnm y 2.322 h.), y Rolim de Moura (261 msnm y 55.807 h.), en homenaje al primer Capitán General de Mato Grosso Antônio Rolim de Moura Tavares. Fue el governador Rolim de Moura quien logró con la crisis del oro en Cuiabá en la década de 1750 la apertura de la ruta comercial del Guaporé-Mamoré-Madeira-Amazonas, que ligaria Vila Bela da Santíssima Trindade a Belém do Pará, em carta dirigida a Diogo Mendonça Corte Real de mayo de $1752 .{ }^{153}$

152 para una cosmología caníbal y ritos festivos de depredación recíproca, ver Conklin, 2005.

153 Domingues Teixeira, 1998; y Nogueira, 2012. 
Artigo original

Hegemonia - Revista Eletrônica de Relações Internacionais do Centro Universitário Unieuro

ISSN: $1809-1261$

UNIEURO, Brasília, número Especial, 2016, pp. 121-174.

$Y$ ya en la frontera natural entre Mato Grosso y Rondonia se encuentra el Rio Cabixi, y en el interior del estado de Mato Grosso, a la altura de la ciudad de Vila Bela da Santissima Trindade (279 msnm y 15.138 h.) desemboca por la margen derecha del Guaporé el afluente río Alegre, el cual dista de Cáceres 270 km, u otro día de navegación río arriba por el Alegre y río abajo por el Jaurú (no confundir con el río Juruá o Yuruá, afluente del Amazonas), donde se dá la Interconexión Cuenca AmazonasRio de la Plata. Vila Bela da Santissima había sido la antigua capital de Mato Grosso desde el Tratado de Madrid en 1750 y hasta 1835 en que la capital se trasladó a Bom Jesus de Cuiabá. Esta región fue poblada por negros esclavos fugados de la minería matogrossense y fue célebre por las Quilombolas y por ser la sede originaria de la Dança Do Congo o Congadas. Y luego, más arriba aún en el Guaporé, la localidad de Pontes e Lacerda (289 msnm y 41.741 h.), así designada en homenaje a los cartógrafos coloniales Antonio Pires da Silva Pontes y Francisco José de Lacerda e Almeida, sumando en toda la cuenca del Guaporé 138.825 h..

La localidad de Costa Marques, aquí citada, se caracteriza por su playa donde desovan en el período de bajante millones de tartarugas, experimento natural auspiciado por la Associação Comunitária Quilombola e Ecológica do Vale do Guaporé (Ecovale-RO), que cuida para que amén de los predadores naturales como el yacaré y las pirañas puedan escapar también de la captura humana. Esta cuenca donde en su parte alta se encuentra el Pantanal del Guaporé, fue poblada con criterios de frontera populista, consistente en pequeños agricultores y garimpeiros mestizos y donde abundan suelos antropogénicos de terra preta. ${ }^{154}$

\footnotetext{
154 Browder \& Godfrey, 1997; Hornbor, 2005, 590.
} 
Artigo original

Hegemonia - Revista Eletrônica de Relações Internacionais do Centro Universitário Unieuro

ISSN: $1809-1261$

UNIEURO, Brasília, número Especial, 2016, pp. 121-174.

\section{A-VI.-Sexto tramo o corredor paraguayo-platino (Mapa VII)}

Una vez en el río Paraguay luego de remontar el Quinto Tramo, se llega al Pantanal brasileño, que es el mayor humedal o delta interior del planeta y que en el pasado fue un mito geográfico conocido como la Laguna de los Xarayes (poblada por indios Guató, de la familia lingüistica macroyé). ${ }^{155}$ El Gran Pantanal consiste en una inmensa hoya o depresión geológica, que es sitio de recarga de acuíferos, surcado por el río Taquarí (donde se produce la interconexión con el río Araguaia, afluente del Tocantins, para lo cual hay que vencer una diferencia de niveles de 350 m.), y que en la temporada lluviosa se inunda alcanzando su extensión el millón y medio de $\mathrm{km}$. cuadrados, con una pendiente media de 3,1 $\mathrm{cm} / \mathrm{km}$, y la fluctuación de las crecientes sube a casi cinco metros, ${ }^{156}$ con una fauna y una flora de gran biodiversidad, cuya función o dinámica natural es la de filtrar todo el ecosistema fluvial y la de regularlo actuando como una suerte de mega-esponja. ${ }^{157}$

Para Adámoli (1999), es necesario pensar en el eje fluvial del río Paraguay "...como la columna vertebral del portentoso sistema de humedales

155 viven en la aldea de Uberaba, situada en la Isla Ínsua a orillas de los lagos Uberaba y Gaíva.

156 Perea Borda, 1998, 199. Esta fluctuación es la misma que se da en todos los ríos de la cuenca amazónica aunque con variaciones según la distancia con los macizos cordillerano, guayanés y central platino. Para los humedales del Chaco y el Pantanal, ver Adámoli, 1999.

157 Para un análisis de la conservación de humedales en el Mato Grosso, ver Dugan, 1992. 
Artigo original

Hegemonia - Revista Eletrônica de Relações Internacionais do Centro Universitário Unieuro

ISSN: $1809-1261$

UNIEURO, Brasília, número Especial, 2016, pp. 121-174.

sudamericanos que tienen al Pantanal como componente Norte, al Delta [del Paraná] en el Sur, al Chaco como aporte occidental, y al complejo de los esteros del Iberá y las cañadas correntinas [que deberán ser comunicables con el río Uruguay], y los esteros del Ñeembucú [rinconada que forman los ríos Paraguay y Paraná en territorio paraguayo] como aporte oriental". ${ }^{158}$ Lamentablemente, la protección irrestricta del Gran Pantanal ha sido invocada por ciertos conservacionistas para falsamente atribuir a la Hidrovía Paraguay-Paraná (HPP) la intención de modificar la dinámica hidrológica de este humedal.

El río Alto Paraguay (de 2619 km de extensión, en guaraní significa "espejo grande de agua"), de norte a sur, captura el río Sepotuba (recoge como afluentes los río Juba y Sapo que se originan en la región intermedia entre la Chapada dos Parecis y la Chapada dos Guimarães, poblada antiguamente por índios Boróros y Kaiapós, de la familia lingüística gê); arranca de Barra do Bugres; atraviesa la localidad de Puerto Cáceres, antiguamente Vila Maria do Paraguai (85.274 h.), en homenaje a la reina María de Portugal, donde comienza el Pantanal brasileño, y que comprendiendo el Bajo Paraná se extiende hasta el puerto de Buenos Aires a lo largo de $3.400 \mathrm{~km} .{ }^{159}$ Más luego, navegando un canal inexistente se alcanza Corumbá (significa "lugar distante"), ex fuerte Albuquerque ( $91.697 \mathrm{~h} .$, pendiente media de $3,1 \mathrm{~cm} / \mathrm{km}$, la profundidad varía entre 4 y 10 m., y hasta Asunción se navega con calado de seis

\footnotetext{
158 Ver Adámoli, 1999, 93.
}

159 Se denominó Puerto Cáceres en 1778 en homenaje al cuarto governador y capitangeneral de la capitania de Mato Grosso, Luís de Albuquerque de Melo Pereira e Cáceres. 
Artigo original

Hegemonia - Revista Eletrônica de Relações Internacionais do Centro Universitário Unieuro

ISSN: $1809-1261$

UNIEURO, Brasília, número Especial, 2016, pp. 121-174.

pies), Forte Coimbra (259 h., navegable todo el año contando con una profundidad para embarcaciones de hasta 10 pies de calado), Porto Esperanza (873 h.), y Porto Murtinho (16.500 h.).

En la margen occidental del mismo río Paraguay, desde Cáceres se llega --60 km. más al sur-- a la desembocadura del río Jaurú o Yaurú (era la frontera anterior al Tratado de Límites de 1750, su afluente es el río Aguapey que se origina en la Chapada dos Parecis), y navegando más al sur a lo largo de $600 \mathrm{~km}$. se llega a Corumbá (donde se forma la triple frontera entre Bolivia, Brasil y Paraguay), en el estado de Mato Grosso do Sul, y damos finalmente con el Pantanal paraguayo (Departamento de Alto Paraguay), con la Estación Biológica "Los Tres Gigantes"; y con el Pantanal boliviano (provincia Germán Busch del departamento de Santa Cruz), arribando a Puerto Suárez (19.829 h.), Puerto Quijarro y la zona franca de Puerto Aguirre (16.000 h.), poblado antiguamente por indios payaguás y guaycurúes. Desde Puerto Suárez se puede remontar el Canal Tamengo, sumando 35.829 h. El Canal Tamengo es un acceso habilitado de Bolivia a la Hidrovía Paraguay-Paraná (HPP), y es un afluente del margen derecho del Río Paraguay, de diez km de extensión, que conecta ese río con los Bañados de Otuquis o Tucavaca, entre los cuales se encuentran lagunas tales como Laguna Cáceres, Laguna Mandioré, Laguna La Gaiba y la binacional Laguna Uberaba e Isla Insúa (donde viven los indios Guató antiguamente conocidos como Xarayes). Dichas lagunas en época de lluvias cubren unos $200 \mathrm{~km}$ cuadrados, y sus aguas son utilizadas para lavar mineral de hierro o manganeso procedentes del Cerro Mutún, que se exporta en grandes cantidades vía fluvial. ${ }^{160}$ 
Artigo original

Hegemonia - Revista Eletrônica de Relações Internacionais do Centro Universitário Unieuro

ISSN: $1809-1261$

UNIEURO, Brasília, número Especial, 2016, pp. 121-174.

Bajando por el río Paraguay (a esta altura tiene una pendiente de 6 $\mathrm{cm} / \mathrm{km}$ ) damos en el margen derecho del río con los puertos Olimpo y Casado, y con la desembocadura de los ríos Verde y Monte Lindo, territorio de los indios Ishir, un desprendimiento de los Chamacocos. ${ }^{161} \mathrm{Y}$ en la frontera de Paraguay y Argentina se confronta con el río Pilcomayo o Araguay (nace en las cordilleras orientales del altiplano boliviano, en cuya Laguna Naineck y sus alrededores en Formosa se concentra la producción de bananos y pomelos); y luego con el río Bermejo (nace en Tarija, Bolivia), bañando ambos ríos los territorios del chaco seco. ${ }^{162}$ En sus aguas se inauguraron en 1923 los Aerodeslizadores del Rio Bermejo para pasajeros y cargas livianas con motores de aviación del Ministerio de Obras Públicas de la Nacion. Entonces, antes de la confluencia con el Paraná, el río Paraguay recibe aguas procedentes del macizo charqueño. $Y$ en la margen izquierda del mismo río damos primero con la desembocadura del río Cuiabá (por donde había pasado el explorador Georg Heinrich von Langsdorff en 1825, Theodor Roosevelt en 1914, y la Columna Prestes en 1927); más abajo las aguas del río Branco, antigua frontera entre Brasil y Paraguay, que fue abdicada por Paraguay a

160 Los primeros seis $\mathrm{km}$. son de soberanía compartida con el Brasil; y los restantes cuatro km desde Arroyo Concepción hasta la desembocadura en el Río Paraguay, son de soberanía del Brasil

161 Para la performance de los indios Ishir de Paraguay, ver Mendoza, 2007; y Escobar, 2007. Para los descubridores de la laguna Pitiantuta, que significa "lugar del oso hormiguero muerto" en el idioma de los indios Chamacocos (por el general ruso Juan Belaieff, con sus compatriotas Von Eckstein y Serebriakoff, y el paraguayo teniente Hermes Saguier), en el Chaco Boreal, cuya posesión en 1931 desató la Guerra del Chaco, ver Richard, 2008. Para el liderazgo y el control social entre los chamacoco del Gran Chaco, ver Braunstein y Meichtry, 2008.

162 el prefijo "pilco" del nombre Pilcomayo en quechua significa rojo. 
Artigo original

Hegemonia - Revista Eletrônica de Relações Internacionais do Centro Universitário Unieuro

ISSN: $1809-1261$

UNIEURO, Brasília, número Especial, 2016, pp. 121-174.

posteriori de la Guerra; y más abajo aún el río Apa (cuyos afluentes los ríos Pirapucú, Caracol y Perdido bajan de la serra Boquedana, Mato Grosso do Sul), que hace de límite entre Brasil y Paraguay (600 km. más al sur de la frontera anterior que pasaba por los ríos Jaurú o Yaurú y Branco), y que es parte de una sabana húmeda tropical que se denomina el cerrado brasilero (la quinta parte del Brasil), territorio arable y geológicamente más antiguo que la amazonía, pues pertenece al precámbrico, y cuyo imaginario sabánico vino a desplazar el imaginario del sertao. ${ }^{163}$

Y siguiendo en la margen izquierda pero en territorio paraguayo damos con puerto Vallemí o Concepción, antigua Villa Real de la Concepción (76.000 h., sin dragados la profundidad es de 5,8 m.), con puerto Risso (productor de cal hidratada) de costa borrascosa, y con la ciudad capital de Asunción (513.399 h., profundidad media de 5 m., bajando hasta Rosario lleva tres días y medio de navegación), con la población de Villeta (36.228 h.) y con los esteros del Ñeembucú. ${ }^{164}$ Inmediatamente, el río Paraguay entronca con el río Paraná (2739 km de longitud, en guaraní significa "madre del mar"), y subiendo por este último río y bordeando en la margen sur con la provincia de Corrientes se alcanza primero Yaciretá (km 1455); luego la selva misionera (Posadas), territorio frecuentado por el novelista argentino Horacio Quiroga, donde los guaraníes cultivaban sus yerbas chamánicas; más arriba se llega al río Tieté (ahora tiene seis

163 El Cerrado cubre dos millones de $\mathrm{km}^{2}$, que incluye el estado de Goiás, la mayor parte de Mato Grosso, y el estado de Tocantins, la parte occidental de Minas Gerais y Bahía, y la parte sur de Maranhão y Piauí. El Cerrado se extiende al oriente de Bolivia, y al noreste y centro de Paraguay. Por sabana y su gentilicio sabánico se entiende un ecosistema caracterizado por un estrato arbóreo-arbustivo en el que el dosel arbóreo tiene escasa cobertura, que permite un estrato herbáceo o arbustivo contínuo y alto

164 El manguruyú sacado del río Paraguay pesaba $70 \mathrm{~kg}$. 
Artigo original

Hegemonia - Revista Eletrônica de Relações Internacionais do Centro Universitário Unieuro

ISSN: $1809-1261$

UNIEURO, Brasília, número Especial, 2016, pp. 121-174.

centrales hidroeléctricas), en el estado de San Pablo; y más arriba aún se alcanza la Serra da Mantiqueira (montaña que Ilora), en Mina Gerais, donde se origina el río Paraná. ${ }^{165}$ Y en la misma Mina Gerais, donde afloran las tres serranías, la de Mantiqueira, Ibitipoca y Canastra, nace en esta ultima el río San Francisco, que baja hacia el norte hasta el Atlántico a la altura de Bahía, territorio donde se prolongaba para los guaraníes la búsqueda de la tierra sin mal.

Esta búsqueda incansable de un paraíso perdido lo practicaban los indios guaraníes --como lo comprobó en carne propia a comienzos del siglo XX el malogrado etnólogo alemán Curt Unkel Nimuendajú-- desde el poniente hacia el naciente, desde el piedemonte andino hasta el propio mar Atlántico, alcanzando así todos los rincones del hinterland amazónico, chaqueño y platino, incluída las amazonías brasilera, venezolana, colombiana, ecuatoriana y peruana, sin que ningún istmo, frontera terrestre o humedal (pantanal) fuera un obstáculo para su milenaria peregrinación. ${ }^{166}$ El único obstáculo que habría frenado la migración guaranítica por el río Amazonas, remontando río arriba hacia occidente, fue la presencia de la etnía arahuaca que había entrado hacía siglos al Amazonas por el río Negro, procedente del Orinoco.

\footnotetext{
165 Para las yerbas chamánicas, ver Keller, 2011.

166 para la leyenda sobre la creación y destrucción del mito de la tierra sin mal, ver Villar y Combés, 2013; y Turtera Pereira, 2009, 37 y 51. Y para los jefes de la sociedad Guaraní en el paradigma de Clastres cuestionado por Santos Granero, ver Banno, 2009.
} 
Artigo original

Hegemonia - Revista Eletrônica de Relações Internacionais do Centro Universitário Unieuro

ISSN: $1809-1261$

UNIEURO, Brasília, número Especial, 2016, pp. 121-174.

Este mecanismo fluvial ancestral recoge el tráfico de gran cantidad de jurisdicciones chaqueñas, brasileras, bolivianas, paraguayas, mesopotámico-litoraleñas y platinas. En la ribera oriental del río Paraguay, pese al intenso mestizaje registrado desde la conquista española (el fundador de Asunción, Martínez de Irala, había sellado una alianza con los guaraniés de mutua defensa e intercambio de mujeres, contra la ofensiva de los indios del chaco, Tobas y Matacos), subsistieron medio millar de comunidades o aldeas habitadas por una veintena de pueblos ancestrales distribuídos por trece departamentos, con un total aproximado a las cien mil personas. Estos grupos étnicos fueron clasificados en media docena de grupos lingüísticos: de la familia guaraní los aché o guayaki, los avá guaraní o chiripá y los guaraní ñandevá o tapieté y su dialecto apapokúva (el mismo que estudiara el etnólogo alemán Kurt Unckel Nimuendajú); de la familia mbyá, los paítavyterá o kaiwá en Brasil; de la familia mataco-mataguayo, los nivaclé o chulupí, los manjuí o chorotes, y los maká; de la familia zamuco, los ayoreo, los ybytoso o chamacocos, y los tomarhao; y de la familia maskoy, los enlhet, enxet, angaité, sanapaná, y guaná.

El Alto Paraná (de 2739 km de extensión) está poblado río arriba por puertos como Encarnación (91 msnm y 100.000 h.), capital del departamento de Itapúa, Presidente Franco, Posadas (120 msnm y 200.000 h. ), la represa binacional de Itaipú, que ha producido un desnivel de 120 m., Saltos del Guayrá-Guayrá (146 msnm y 100.000 h.), Ciudad del Este (185 msnm y 223.000 h.), y Pedro Juan Caballero-Ponta Porá (660 msnm y 84.000 h.). Dicho Alto Paraná, formado por la unión de los ríos Grande y Paranaíba, recoge las aguas de sus afluentes de la margen derecha, los ríos Aporé, Sucuriú, Verde, Pardo, Invinhema y Amambay; y 
Artigo original

Hegemonia - Revista Eletrônica de Relações Internacionais do Centro Universitário Unieuro

ISSN: $1809-1261$

UNIEURO, Brasília, número Especial, 2016, pp. 121-174.

la de sus afluentes de la margen izquierda, los ríos Tieté (que atraviesa todo el estado de Sao Paulo donde se encuentra Porto Feliz (50.000 h.), Paranápanema (navegando este río partieron las primeras bandeiras), Ivaí e Iguazú, donde se encuentra Foz de Iguazú (164msnm y 253.000 h.). Bajando por el río Paraná, se recoge de norte a sur en el Bajo Paraná, por su margen izquierdo (que tiene la barranca más alta), las localidades de Corrientes (56 msnm y 258.000 h., su calado actual informado para comercio nacional e internacional es de 9 a 12 pies, cuya distancia fluvial con Asunción lleva cinco [5] días de navegación agua arriba, corriente en contra y a motor), y el puerto de Goya (48 msnm, 77.349 h., y el calado máximo es de 20 pies y el mínimo de 8 pies); la desembocadura del río Corrientes y a sus orillas la localidad de Esquina (44 msnm y 19.081 h., con un calado máximo de 8,3 pies); y más abajo La Bajada o ciudad de Paraná ( 89 msnm y 207.041 h. ). ${ }^{167}$ Y por su margen derecha la localidad de Resistencia (48 msnm y 230.000 h., con un calado de 2,10 metros o siete pies de profundidad), las desembocaduras de los ríos San Javier y Salado, y a su vera las ciudades de Helvecia (27 msnm y 8.000 h.), Cayastá ( 26 msnm y 2043 h.), y la capital Santa Fé (62 msnm, 350.000 h., con profundidad de 7,5 metros hasta Santa Fe), y más abajo las ciudades de Rosario (23 msnm, 1.000.000 h., y la profundidad de 10,5 metros hasta Rosario), Villa Constitución (22 msnm y 48.356 h.), San Pedro (31 msnm y 47452 h.), Zárate (27 msnm y 98.522 h.), y Tigre (2 msnm) y finalmente el Delta del Paraná, cuya función de humedal, a juicio del Ing. Agr. Jorge Adámoli, se combina íntimamente con los humedales

167 En La Bajada (hoy ciudad de Paraná) aflora el Mioceno marino estudiado por Darwin, ver Iriondo y Kröhling, 2009. 
Artigo original

Hegemonia - Revista Eletrônica de Relações Internacionais do Centro Universitário Unieuro

ISSN: $1809-1261$

UNIEURO, Brasília, número Especial, 2016, pp. 121-174.

de Santa Fé a la vera del río Paraná, los esteros de Iberá y con el Gran Pantanal matogrossense. ${ }^{168}$

En el Delta del Paraná donde los ríos se interconectan desemboca el río Uruguay (1770 km de longitud, pendiente de 2,9 cm/ km, en guaraní significa "río de los pájaros pintados"), cuya barranca más alta está en la margen izquierda del río. Remontando su margen derecha, se llega primero en el Bajo Uruguay a las ciudades fundadas por Tomás de Rocamora en el siglo XVIII, de Gualeguaychú (15 msnm y 102.421 h.), y Concepción del Uruguay, ex Arroyo de la China (3 msnm y 75.000 h., frente a Paysandú, ROU), a orillas de la desembocadura del río Gualeguay, en cuya cuenca se halla Puerto Ruiz ( $8 \mathrm{msnm}$ ). Más arriba, en la provincia de Entre Ríos, se encuentra la desembocadura del Yuquerí Grande donde se asientan las localidades de Concordia ( $21 \mathrm{msnm}, 116.485$ h., a la cual se puede llegar con un calado de 2,70 mts, frente a Salto, ROU) y el Salto Grande (hidroeléctrica); y llegando a Corrientes la localidad de Monte Caseros ex Paso de Higos (35 msnm y 23.470 h., frente a Bella Unión, ROU y Barra do Quaraí, Rio Grande do Sul, formando entre las tres ciudades una triple frontera); y más arriba la ciudad de Paso de los Libres (70 msnm y 40.494 h., frente a Uruguaiana, $\mathrm{Br}$ ); y las tres ciudades del Corredor Jesuítico Guaraní: La Cruz (56 msnm y 7133 h.); Alvear (56 msnm, y 6732 h., frente a Puerto Itaqui, Br); y Santo Tomé (67 msnm y 23.299 h., frente a Sao Borja, Br). Y más arriba aún, en el Alto Uruguay, provincia de Misiones, la población de Yapeyú (56 msnm, cuna del libertador José de San Martín), y las aguas del río Pepirí Guazú y los saltos del Moconá; teniendo el río Uruguay su origen en la Serra do Mar (Santa

168 sobre el rol de Darwin en las descripción de las barrancas del Paraná, ver Iriondo y Kröhling, 2009. 
Artigo original

Hegemonia - Revista Eletrônica de Relações Internacionais do Centro Universitário Unieuro

ISSN: $1809-1261$

UNIEURO, Brasília, número Especial, 2016, pp. 121-174.

Catarina, Brasil), de la unión de sus afluentes Canoa y Pelotas, región donde se encuentra la ciudad de São Joaquim (1360 msnm y 25.122 h.), y donde en invierno nieva y se la conoce como la Suiza de Brasil.

Subiendo ahora por la margen izquierda del río Uruguay, en territorio uruguayo, se encuentra en el Bajo Uruguay el puerto de aguas profundas de Nueva Palmira (15 msnm y 10.000 h., con un calado operable de 32 pies o 9,70 m.), y más arriba la desembocadura del río Negro, a cuyas orillas se encuentran las ciudades de Mercedes (20 msnm y 41.900 h. ), y Villa Soriano o Santo Domingo de Soriano (5 msnm y 1.124 h.). Más arriba en el Uruguay, damos con las localidades de Fray Bentos (23 msnm y 24.406 h., frente a Gualeguaychú, ER), Paysandú (34 msnm y 76.412 h., frente a Concepción del Uruguay, ER), y Salto (48 msnm y 104.000 h., frente a Concordia, ER); y más arriba aún la localidad de Bella Unión (54 msnm y 12200 h.) y las aguas del río Cuareim, donde se forma la triple frontera entre Uruguay (Bella Unión), Argentina (Monte Caseros) y Brasil (Barra do Quaraí). Más arriba en el río Uruguay, se encuentra la localidad brasileña de Uruguaiana (66 msnm y 116.276 h., frente a Paso de los Libres, Corrientes), y más arriba las aguas del río Ibicuí (en guaraní "agua de la tierra de arena"), antigua frontera entre Brasil y Uruguay que fue abdicada por Uruguay en 1862, y donde en tiempos coloniales se celebraban enormes corambres o vaquerías. Ascendiendo por el río Uruguay se llega a los puertos de Itaqui (57 msnm y 41.902 h., frente a Alvear, Ar), y Sao Borja (123 msnm y 66.000 h., frente a Santo Tomé, Corrientes). Ya en el Alto Uruguay, damos con la población de Porto Lucena (114 msnm y 6.000 h., a la altura de Oberá, Misiones), territorios que pertenecieron a los Siete Pueblos de las Misiones Orientales, donde se libró la Guerra Guaranítica (1754) y desde donde sus poblaciones 
Artigo original

Hegemonia - Revista Eletrônica de Relações Internacionais do Centro Universitário Unieuro

ISSN: $1809-1261$

UNIEURO, Brasília, número Especial, 2016, pp. 121-174.

ancestrales fueron finalmente expulsadas en tiempos de la Guerra de las Naranjas (1801). Y remontando el río Quareim se topa con la localidad de Santana do Livramento (208 msnm y 82.500 h.).Y finalmente, en el Río de la Plata, se llega a las capitalesde Montevideo (136 msnm)y Buenos Aires (6 msnm).

Y de las múltiples localidades en el chaco boreal y meridional, primitivamente pobladas a través de sus afluentes (Pilcomayo, Bermejo y Salado) se recogen numerosos grupos étnicos de familia lingüística arawak (chanés), guaraní (chiriguanos), zamuco (chamacocos), macroyé (minuanes y charrúas parientes de los xavantes del río das Mortes, autores del cautiverio, muerte y antropofagia de Juan Díaz de Solís en una isla frente a Carmelo-Uruguay en 1516, y exterminados tres siglos más tarde en la masacre de Salsipuedes, en 1831), mataco-mataguayo (chulupís y chorotés), guaycurú (tobas [khom, en su territorio encontró la muerte en 1882 el explorador francés Jules Crevaux], ${ }^{169}$ abipones, pilagás y matacos [wichi]. ${ }^{170}$ Estas regiones estuvieron antiguamente pobladas por los diaguitas, mediados por los chanás (de la familia arahuaco), quienes habían sido dominados por los tupí-guaranies, con quienes se mestizaron y de cuya mezcla surgieron los chiriguanos; ${ }^{171} \mathrm{y}$ más tarde fueron evangelizados por Menonitas o pietistas rusos. ${ }^{172}$ En su larga historia, sufrieron tres terribles masacres, la primera conocida como

\footnotetext{
169 Para la autoconservación de los Tobas, ver Meabe, 2016.

170 para la espiritualidad indígena wichi, ver Palmer, 2005.

171 estudiados por Métraux, ver Eriksen, 2011, 81.

172 Hernández Medina, 2004.
} 
Artigo original

Hegemonia - Revista Eletrônica de Relações Internacionais do Centro Universitário Unieuro

ISSN : $1809-1261$

UNIEURO, Brasília, número Especial, 2016, pp. 121-174.

la Masacre de Kuruyuki, provocada por la insurrección de los chiriguanos del Isoso, en 1892, en el Chaco boliviano, a orillas del río Parapetí; ${ }^{173}$ la segunda en 1924, de las etnias qom y mocoví, conocida como la Masacre de Napalpí (Chaco, Argentina), de la que fueron testigos dos científicos, el antropólogo alemán Robert Lehmann-Nitsche y el argentino Enrique Lynch Arribálzaga; ${ }^{174}$ y la tercera en 1947, de indios pilagá, toba y wichi, denominada la Masacre de Rincón Bomba (Las Lomitas, Formosa). ${ }^{175}$

Y para todos estos grupos étnicos se viene dando una muy prolífica variedad de estudios científicos. La lengua, literatura y forma de vida de los menonitas germano-parlantes en Paraguay fue estudiada por Hernández Medina (2004). Los grupos étnicos chamacocos o zamucanos vienen siendo analizados por Renshaw (2002). Los ayoreo totobiegosode del Chaco Paraguayo han reivindicado sus propios territorios. ${ }^{176}$ Los mbeguá, mocoretáes y mepenes de la Mesopotamia fueron extinguidos. ${ }^{177} \mathrm{Y}$ los indígenas del Paraguay fueron estudiados por Branislava Súsnik y Miguel Chase-Sardi.

Sumando la población de la totalidad de los seis (6) tramos o corredores correspondientes a los ocho (8) países del circuito amazónico-platino (Bolivia, Perú, Ecuador, Colombia, Brasil, Paraguay, Argentina, Uruguay),

173 estudiados por Susnik $(1968,1975)$ y por Combés (2005).

174 sobre la Masacre de Napalpí, ver Vidal, 2008. Para revisitar Napalpí, ver Salamanca, 2009.

175 sobre la Masacre de Rincón Bomba, ver Van Bredam, 2009.

176 ver Casaccia, 2008.

177 ver Bartolomé, 2003. 
Artigo original

Hegemonia - Revista Eletrônica de Relações Internacionais do Centro Universitário Unieuro

ISSN: $1809-1261$

UNIEURO, Brasília, número Especial, 2016, pp. 121-174.

nos da un monto total aproximado a casi treinta millones de habitantes, de los cuales tres millones son indígenas distribuídos en 400 pueblos que hablan 250 lenguas diferentes correspondientes a medio centenar de familias lingüísticas, muy superior a la población de sus puertos interiores que totalizan sólo una sexta parte, unos cinco millones. 
Artigo original

Hegemonia - Revista Eletrônica de Relações Internacionais do Centro Universitário Unieuro

ISSN: $1809-1261$

UNIEURO, Brasília, número Especial, 2016, pp. 121-174.

\section{Bibliografía cartográfica}

Da Silva Alves, Luiz Eduardo (2008): La Navegación Fluvial en Brasil, en Seminario Internacional sobre Desarrollo de Puertos Fluviales e Hidrovías (Iquitos, Perú: Antaq);

Perea Borda, Jorge ed. (1998): Los ríos nos unen. Integración Fluvial Suramericana (Santafé de Bogotá: Corporación Andina de Fomento);

\section{Bibliografía general}

Abad, Jorge D.; Jorge Vizcarra, Jorge Pasredes, Hugo Montoro, Christian Frías, y Carlos Holguín (2013): Morphodynamics of the Upper Peruvian Amazonian Rivers, Implications into Fluvial Transportation, International Conference (Iquitos, Peru);

Adámoli, Jorge (1999): Los Humedales del Chaco y del Pantanal, en: Adámoli, J. y A. I. Malvárez (eds). Tópicos sobre humedales subtropicales y templados de Sudamérica (UNESCO), 87-99; 
Artigo original

Hegemonia - Revista Eletrônica de Relações Internacionais do Centro Universitário Unieuro

ISSN: $1809-1261$

UNIEURO, Brasília, número Especial, 2016, pp. 121-174.

Adelaar, Willem F. H. (2000): "Propuesta de un nuevo vínculo genético entre dos grupos lingüísticos indígenas de la Amazonía occidental: Harakmbut y Katukina". en: Miranda Esquerre, vol. 2, pp. 219-36

Agüero, Oscar Alfredo (1996): La política indigenista estatal en la Amazonia Peruana

- GT. Política Indigenista XX Encontro Anual de ANPOCS - Caxambu, outubro de 1996

Aguilera-Reza, Genaro (2014): The Story of Drug Traficking in Latin America Borderland Beat

Aizcorbe Sagrera, Jordi (2011): El Proyecto Reformador del General José Ballivián. La Consturcción del Estado-Nación durante el Gobierno Provisional de 1841-1843, Boletín Americanista, Año Ixi.1, no 62, Barcelona, 2011, pp. 137-156, ISSN: 0520-4100 137

Albergaria de Queiroz, Fábio (2013): Hidropolítica e Segurança: uma perspectiva a partir da governança das águas platinas no âmbito do Complexo Regional

Albert, Bruce (2004): A propósito del movimiento indígena en la Amazonia brasileña, en Alexandre Surrallés, y Pedro García Hierro, ed., Tierra Adentro. Territorio indígena y percepción del entorno, IWGIA, 221-258;

Alden, Dauril (1987): Late colonial Brazil, 1750-1808, en Leslie Bethel ed., Colonial Brazil (NY: Cambridge University Press), 284-344; 
Artigo original

Hegemonia - Revista Eletrônica de Relações Internacionais do Centro Universitário Unieuro

ISSN: $1809-1261$

UNIEURO, Brasília, número Especial, 2016, pp. 121-174.

Alexiades, Miguel N. (1999): Ethnobotany of the Ese Eja: Plants, Health, and Change in an Amazonian Society, dissertation in Biology, The City University of

New York.1999

Alexiades, Miguel N. ed. (2013): Mobility and Migration In Indigenous Amazonia: Contemporary Ethnoecological Perspectives (New York and. Oxford: Berghahn);

Allen, Mark W y Terry L Jones, ed. (2014): Violence and Warfare among Hunter-Gatherers, e-book;

Alvarez, Ricardo Javier (2000): Régimen Internacional de las Vías Navegable Interiores.

Álvarez Hoyos, María Teresa (2012): Pasto y sus intentos modernizadores en el período de la República Liberal (1930-1946), Revista Historia y Memoria [en línea], No. 5. Año 2012, pp. 201 - 223

Álvarez Lobo, Ricardo (1960): Los Piros: Leyendas, mitos, cuentos

Álvarez Lobo, Ricardo (1984): TSLA, estudio etno-histórico del Urubamba y Alto Ucayali Editorial San Esteban, 1984

Amiune, José (2005): La Hidrovia como Proyecto Macrologístico 
Artigo original

Hegemonia - Revista Eletrônica de Relações Internacionais do Centro Universitário Unieuro

ISSN: $1809-1261$

UNIEURO, Brasília, número Especial, 2016, pp. 121-174.

Amoroso, Marta (1992): "Corsários no caminho fluvial: Os Mura do rio Madeira." En: Carneiroda Cunha, Manuela (ed.): História dos índios no Brasil. São Paulo: Companhia das Letras, pp. 297-310;

Andrade Ribeiro de Oliveira, Myriam y Mariela Brazón Hernández (2001): La Epopeya jesuítica en el Amazonas Brasilero y sus imágenes, III Congreso Internacional de Barroco Ibero-Americano (Universidad Pablo de Olavide),

Andriolo, Karin (1978): Brief Review: On Power in Egalitarian Societies, Dialectical Anthropology, 3, 193-194;

Angulo Puente Arnao, Juan (1927): Historia de los límites del Perú, Ciudad: Lima. Editorial: Impr. de la Intendencia

Anónimo, La Selva en la Guerra con Chile [en línea]

Apffel-Marglin, Frédérique (2013): Tierra Negra: don de los pueblos amazónicos a la regeneración global, en Varese, Stefano; Frédérique Apffel-Marglin; y Róger Rumrrill (coordinadores), Selva Vida. De La Destrucción de la Amazonía al Paradigma de la Regeneración (Editorial: IWGIA), 31-60;

Araújo, Roberto (2006): Commentaire de la communication "De la "communauté" aux "populations traditionelles": aspects de la modernité amazonienne, Dec 2006, Paris, France

Arcila Niño, Oscar; González León, Gloria; Gutiérrez Rey, Franz; Rodríguez Salazar, Adriana; Ariel Salazar, Carlos (2000): Caquetá 
Artigo original

Hegemonia - Revista Eletrônica de Relações Internacionais do Centro Universitário Unieuro

ISSN: $1809-1261$

UNIEURO, Brasília, número Especial, 2016, pp. 121-174.

construcción de un territorio amazónico en el siglo XX Editor: Bogotá SINCHI 2000

Arenz, Karl Heinz (2010): Do Alzette ao Amazonas: vida e obra do padre Joao Felipe Bettendorff (1625-1698), Revista Estudos Amazonicos, v.V, n.1, 25-78;

Arenz, Karl Heinz (2014): Além das doctrinas e rotinas: Indios e missionarios nos aldeamentos jesuíticos da Amazonia portuguesa (séculos XVII e XVIII), Revista Historia e Cultura (Franca, SP), v.3, n.2, 63-88;

Arias García, Juan Carlos (2007): Oferta de productos forestales maderables y no maderables con potencial económico en un bosque de tierra firme de la Amazonia colombiana, en: Colombia ed: Editora Guadalupe Ltda , v.1 , p.279 - 303;

Arvelo-Jiménez, Nelly (2012): Fragmentación y reconstitución étnica, Presente y Pasado. Revista de Historia, n.34, 41-64;

Arze Aguirre, René D. (2003a): Alcide D’Orbigny en la visión de los Bolivianos, Bull. Inst. fr. études andines, 2003, 32 (3): 467-477;

Arze Aguirre, René D. (2003b): El naturalistafrancés Alcide d'Orbigny en la visión de los bolivianos (La Paz, Embajada de Francia-IFEAPluraleditores, 2003; 402 p. 
Artigo original

Hegemonia - Revista Eletrônica de Relações Internacionais do Centro Universitário Unieuro

ISSN: $1809-1261$

UNIEURO, Brasília, número Especial, 2016, pp. 121-174.

Avarello, Vito (2015): L'oeuvre italienne de Matteo Ricci: anatomie d'une rencontré chinoise (Paris);

Bacchetta, Vittorio L. (1984): Geopolítica, conflictos fronterizos y guerras locales en América Latina, AfersInternacionals, n.4, Estiú 1984;

Bacellar, Sarasvati de Araujo (2012): Surrounding Amazonia: the 163739 Teixeira expedition, knowledge and representation, MA The University of Texas at Austin

Badia Malagrida, Carlos (1919): El factor geográfico en la política sudamericana (Madrid, 1919),

Bahamón, Misael Kuan S.J. (2013): La Misión Capuchina en el Caquetá y el Putumayo, 1893-1929, tesis de Maestría en Historia, Facultadde Ciencias Sociales Pontificia Universidad Javeriana;

Ballón Aguirre, Enrique (2006). Tradición oral peruana. Literaturas ancestrales y populares. Fondo Editorial de la Pontificia Universidad Católica del Perú, Lima, 2 volúmenes.

Banno, Tetsuya (2009): El Poder Político y los Jefes en la Sociedad Guaraní: Entre el paradigma de Pierre Clastres y el análisis de las figuras presentadas en los documentos del siglo XVI;

Barandiarán, Daniel de (1992): El Orinoco Amazónico de las Misiones Jesuíticas. En Rey Fajardo, José del (ed.). Misiones jesuíticas en la 
Artigo original

Hegemonia - Revista Eletrônica de Relações Internacionais do Centro Universitário Unieuro

ISSN: $1809-1261$

UNIEURO, Brasília, número Especial, 2016, pp. 121-174.

Orinoquía. San Cristóbal: Universidad Católica del Táchira, 1992, t. II, p. $129-360$

Barata Souza, Leno José (2011): Os Flutuantes Antes da "Cidade Flutuante", Fronteiras do Tempo, vol. 1, no 1 - Junho de 2011

Barcelos Neto, Aristoteles (2008): Apapaatai: rituais de máscaras no Alto Xingu. São Paulo: Editora da Universidade de São Paulo, 310p. Foreword by Michael Heckenberger.

[download PDF review].

Barcelos Neto, Aristoteles (2004): Visiting the Wauja Indians: Masks and Other Living Objects from an Amazonian Collection. Lisbon: Museu Nacional de Etnologia, 126p. Foreword by Joaquim Pais de Brito. [download PDF review].

Barclay Rey de Castro, Frederica (2001): Olvido de una historia. Reflexiones acerca de la historiografía andino-amazónica, Revista de Indias, v.LXI, n.223;

Barclay Rey de Castro, Frederica (2009): El estado federal de Loreto, 1896. Centralismo, descentralismo y federalismo en el Perú, Centro de Estudios Regionales Andinos Bartolomé de Las Casas-CBC, Travaux de I'IFÉA

Bareiro Saguier, Rubén y León Cadogan (1980): Literatura guaraní del Paraguay, Fundacion Biblioteca Ayacucho, Jan 1, 1980 
Artigo original

Hegemonia - Revista Eletrônica de Relações Internacionais do Centro Universitário Unieuro

ISSN: $1809-1261$

UNIEURO, Brasília, número Especial, 2016, pp. 121-174.

Barona Tovar, Fernando (2007): Chamanismo, Tiempos y Lugares Sagrados: Memorias del Seminario Internacional, Programa Editorial Universidad del Valle

Bartolomé, Miguel Alberto (2003): Los pobladores del "Desierto" genocidio, etnocidio y etnogénesis en la Argentina, Cuad. antropol. soc. v.17 n.1, Buenos Aires, ene./ago. 2003

Bastian, Jean Pierre (1997): La mutación religiosa en América Latina: para una sociología del cambio social en la modernidad periférica. México D. F.: Fondo de Cultura Económica.

Bastian, Jean Pierre (2006): De los protestantismos históricos a los pentecostalismos latinoamericanos: Análisis de una mutaciónreligiosa, Revista de Ciencias Sociales (Cl), núm. 16, 2006, pp. 38-54

Bastos, Francisco Inácio y Magali Romero Sá (2011): The scientist as historian: Paulo Vanzolini and the origins of zoology no Brasil, Historia, ciencia, saude-Manginhos, vol.18, n.4;

Bates, Diane C. (2007): The Barbecho Crisis, La Plaga del Banco, and International Migration. Structural Adjustment in Ecuador's Southern Amazon, Latin American Perspectives, 34,3: 108-122.

Batista da Silva, Eliezer (1996): Infrastructure for Sustainable Development and Integration of South America (Ed. Expressao\& Cultura) 
Artigo original

Hegemonia - Revista Eletrônica de Relações Internacionais do Centro Universitário Unieuro

ISSN: $1809-1261$

UNIEURO, Brasília, número Especial, 2016, pp. 121-174.

Batista da Silva, Eliezer y Júlio César Suzuki (2012): A Ideologia Espacial

Constitutiva do Estado Nacional Brasileiro, Scripta Nova, Revista Electrónica de Geografía y Ciencias Sociales, Universidad de Barcelona, Vol. XVI, núm. 418 (6),

Bauer, Daniel (2014): Identities on the Periphery: Mestizaje in the Lowlands of South America, Delaware Review of Latin American Studies, v.15. n.2;

Bazoberry Chali, Oscar (2011): Chaco Boreal: ¿Una o muchas regiones?, http://www.alainet.org/es/active/45975

Beck, S.G.; J. Sarmiento, N. Paniagua Z.; C. Miranda \& M.O. Ribera (2000): Humedales de Bolivia, una aproximación a su conocimiento actual, Anales de la Acad. Nac. de Agron. y Vet. , Tomo LIV;

Belaunde, Luisa Elvira (2011): Visión de espacios en la pintura del sheripiari asháninka Noe Silva Morales (Universidad Nacional de Colombia)

Bello, Walden (1998): U.S. Imperialism in the Asia-Pacific, Peace Review, 10:3 (1998), 367-373;

Beluco, Alexandre y Paulo Kroeff de Souza (2014): Energy at the Junction of the Rivers Negro and Solimões, Contributors of the Amazon River, in the Brazilian Amazon, International Scholarly Research Notices, Volume 2014 (2014), 
Artigo original

Hegemonia - Revista Eletrônica de Relações Internacionais do Centro Universitário Unieuro

ISSN: $1809-1261$

UNIEURO, Brasília, número Especial, 2016, pp. 121-174.

Berdichewsky, Bernardo ed. (1979) Anthropology and Social Change in Rural Areas, Mouton Publishers.La Haya, Holanda, 1979

Bermúdez, Alexis; María A. Oliveira-Miranda; y Dilia Velázquez (2005): La investigación etnobotánica sobre plantas medicinales: Una revisión de sus objetivos y enfoques actuales, Interciencia, INCI v.30 n.8 Caracas ago. 2005

Bermúdez Martínez, María (2001): La Incertidumbre de lo Real: Bases de la Narrativa de Juan José Saer (Oviedo: Departamento de Filología Española);

Besouchet, Lidia (1949): Rio Branco e as relaçoes entre o Brasil e a República

Argentina. Rio de Janeiro, Depto. Imprenta Nacional, 1949;

Bevis, Michael, Douglas Alsdorf, Eric Kendrick, Luiz Paulo Fortes, Bruce Forsberg, Robert Smalley Jr., y Janet Becker (2005): Seasonal fluctuations in the mass of the Amazon River system and Earth's elastic response, Geophysical Research Letters, v.32, n.16;

Bidney, David (1963): So-Called Primitive Medicine and Religion, en lago Galdston (ed.), Man's Image in Medicine and Anthropology (New York: International Universities Press), 141-156;

Block, David (1997): La cultura reduccional de los Llanos de Mojos: tradición autóctona, empresa jesuítica y política civil, 1660-1880. Sucre: historia boliviana, 1997; 
Artigo original

Hegemonia - Revista Eletrônica de Relações Internacionais do Centro Universitário Unieuro

ISSN : $1809-1261$

UNIEURO, Brasília, número Especial, 2016, pp. 121-174.

Bodley, John (2013): Los Asháninka: custodios de la biodiversidad en la Amazonía peruana, en Varese, Stefano; Frédérique Apffel-Marglin; y Róger Rumrrill (coordinadores), en Selva Vida. De La Destrucción de la Amazonía al Paradigma de la Regeneración (Editorial: IWGIA), 163-178;

Boidin, Capucine (2006): "Jopara: una vertiente sol y sombra del mestizaje." en Wolf Dietrich y Haralambos Symeonidis (eds.). Tupí y Guaraní. Estructuras, contactos y desarrollos. Münster: Lit-Verlag. Número 11 de la collección "Regionalwissenschaften Lateinamerika". Centro Latinoamericano, 2006. p.303-331

Bonavía Berber, Duccio (1968): Las ruinas de Abiseo (Lima: Universidad de Ciencias y Tecnología)

Bonetto, Argentino A. (1998): Revisión. Panorama sinóptico sobre la ictiofauna, la pesca y piscicultura en los ríos de la cuenca del Plata, con especial referencia al Paraná. Rev. Ictiol., 6(1/2): 3-16;

Bonilla, Víctor (1969): Siervos de dios y amos de indios: el estado y la misión capuchina en el Amazonas. Bogotá: Stella, 1969.

Bordonaro, Federico (2015): Exploring Geopolitics, Geoeconomics and Geostrategy,

Borja, Miguel (2010): Silvícolas, siringueros y agentes estatales: El surgimiento de una sociedad transfronteriza en la Amazonia de Brasil, Perú y Colombia, 1880-1932. Bogotá, Universidad Nacional, 2008, 430 p. 
Artigo original

Hegemonia - Revista Eletrônica de Relações Internacionais do Centro Universitário Unieuro

ISSN: $1809-1261$

UNIEURO, Brasília, número Especial, 2016, pp. 121-174.

De Carlos Zárate Botía, Analisis

Politico, vol.23, no.68, Bogotá Jan./Apr. 2010;

Boster, James S.; James Yost, Catherine Peeke (2003): «Rage, Revenge, and Religion: Honest Signaling of Aggression and Nonaggression in Waorani Coalitional Violence». Ethos 31 (4): 471-494

Botelho Lucidio, João Antonio (2013): 'A Ocidente do Imenso Brasil': as conquistas dos ríosParaguai e Guaporé (1680-1750), tesis doctoral

Bourdy, Geneviève; S. J. Dewalt, L. R. Chávez de Michel, A. Roca, E. Deharo, V. Muñoz, J. A. Bravo, C. Quenevo y A. Gimenez (2000): Ethnobotanical and ethnopharmacological investigation among an Amazonian Bolivian ethnic group, the Tacana,

Brandhuber, Gabriele (1999): Why Tukanoans migrate ? Some remarks on conflict on the Upper Rio Negro (Brazil), Journal de la Société des Américanistes $\square$ Année $1999 \square$ Volume 85, Numéro 85, pp. 261-280

Braudel, Fernand (1976): El Mediterráneo y el mundo mediterráneo en la época de Felipe IIFondo de Cultura Económica, $2^{a}$ ed., Madrid 1976

Braunstein, José y Meichtry, Norma (2008): Liderazgo. Representatividad y control social en el Gran Chaco (EUDENE Editorial Universitaria);

Briceño, Marcos Falcón de (1859): Límites del Brasil con Venezuela 
Artigo original

Hegemonia - Revista Eletrônica de Relações Internacionais do Centro Universitário Unieuro

ISSN: $1809-1261$

UNIEURO, Brasília, número Especial, 2016, pp. 121-174.

Bridikhina, Eugenia (2015): La frontera boliviano-brasileña en construcción (principios del siglo $x x$ ). Los conflictos territoriales, fiscales y legales. La columna Prestes en el territorio boliviano, Memorias: revista digital de historia y arqueología desde El Caribe, No. 26, 2015

Brochado, J. (1989): A Expansao dos Tupi e da Ceramica da Tradicao Policromica Amazonica, Dedalo (Sao Paulo), 27: 65-82;

Browder, John O. y Brian J. Godfrey (1996): Disarticulated Urbanization in the Brazilian Amazon, Geographical Review, Vol. 86, No. 3, Latin American Geography (Jul., 1996), pp. 441-445

Brown, Lester R. (2001): Eco-economía, es possible otro crecimiento, ecológico y duradero (Seuil).

Brown, Michael F. (1993): Facing the State. Facing the World: Amazonia's Native Leaders and the New Politics of Identity, L'Homme, 33: 2-4;

Bruce, Albert, Francois-Michel Le Tourneau. (2007): Ethnogeography and Resource Use among the Yanomami. Current Anthropology, University of Chicago Press, 2007, 48 (4), pp.584-592.

Brust, Monique (2007): Corpo submisso, corpo produtivo: Os jesuítas e a doutrinação dos indígenas nos séculos XVI e XVII, Dossiê Religião, N.4 abril 2007/julho 2007 
Artigo original

Hegemonia - Revista Eletrônica de Relações Internacionais do Centro Universitário Unieuro

ISSN: $1809-1261$

UNIEURO, Brasília, número Especial, 2016, pp. 121-174.

Buckley, Richard (1992): Amazonia: An Ecological Crisis (Understanding Global Issues) Cornelsen Verlag Paperback

Buela Lamas, Alberto (2009): La conexión de las cuencas hidrográficas de Suramérica

Burgos, Manuel (2003): The Witotos and the rubber boom: The silent genocide. A study through the chronicles of explorers of the Amazon basin.

Burke, Brian J. (2012): Transforming power in Amazonian extractivism: historical exploitation, contemporary "fair trade", and new possibilities for indigenous cooperatives and conservation, Journal of Political Ecology. Vol.

Burns, E. Bradford (1958): "Rio Branco e a sua política externa". Revista de

História, n.o 58. Sao Paulo, abril-junio de 1958

Bustamante, Emilio (2013): Modalidades de representación en tres documentales amazónicos peruanos, Contratexto n.o 21, 2013, pp. 165175;

Bustos, Susana (2007): "The Healing Power of the Icaros: A Phenomenological Study of Ayahuasca Experiences" (Ph.D. diss., California Institute of Integral Studies

Cabrera Becerra, Gabriel (2006): Reseña de "Rastros da Memória. Histórias e trajetórias das populações indígenas na Amazônia" de Patrícia 
Artigo original

Hegemonia - Revista Eletrônica de Relações Internacionais do Centro Universitário Unieuro

ISSN: $1809-1261$

UNIEURO, Brasília, número Especial, 2016, pp. 121-174.

Melo Sampaio y Regina de Carvalho Retal (eds.), Fronteras de la Historia, núm. 11, 2006, pp. 482-488

Cabrera Becerra, Gabriel (2007): Los diplomáticos colombianos y la nacionalización de la Amazonía, Memoria \& Sociedad, vol.11, n.22, 5261 ;

Cairo, Carlos del (2006): políticas de la identidad, ciudadanía intercultural y reivindicaciones territoriales indígenas en dos localidades amazónicas, universitas humanística, no.61, enero-junio de 2006 pp: 107-134

Calandra, Horacio Adolfo y Susana Alicia Selceda (2004): Amazonia boliviana: arqueología de los Llanos de Mojos, Acta Amazonica, 155 Vol. 34(2) 2004: 155 - 163

Calavia Sáez, Oscar (1995): O nome e o tempo dos Yaminawa. Etnologia e historia dos Yaminawado Alto Rio Acre. Tesis doctoral/ tese de doutoramento em antropología, DA

FFLCH, Universidade de São Paulo. São Paulo.

Calavia Sáez, Oscar (2005): Kin Paths in an Alien World: Yaminawa, parentesco y lenguaje en Napo

Calavia Sáez, Oscar (2013): Ciencia Amazónica: Notas para un Estudio Críticode los Saberes Nativos.

Calavia Sáez, Oscar (2014): Reynoso y el exotismo, CaféKabul blog de Oscar Calavia 
Artigo original

Hegemonia - Revista Eletrônica de Relações Internacionais do Centro Universitário Unieuro

ISSN: $1809-1261$

UNIEURO, Brasília, número Especial, 2016, pp. 121-174.

cafekabul.blogspot.com/2014/10/reynoso-y-el-exotismo.html

Caldeira, Newman di Carlo (2009): Brasil e Bolívia: fugas internacionais de escravos, navegação fluvial e ajustes de fronteira (1822-1867). Fronteiras, Dourados, v. 11,

n. 19, p. 249-272, jan./jun. 2009.

Calle Restrepo, Horacio (1970): Yarocamena. Estudio de un proceso de desintegración socio-cultural de una comunidad indígena de la Amazonía Colombiana. Tesis. Bogotá: Universidad Nacional

Camargo Piedade, Acacio Tadeu de (2004): O Canto do Kawoká: Música, Cosmologia e Filosofia entre os Wauja do Alto Xingu, Tese apresentada ao Programa de Pós-Graduação em Antropologia Social da Universidade Federal de Santa Catarina, como requisito parcial à obtenção do título de Doutor em Antropologia Social.

Camilo Restrepo, Juan; Ignacio Bentancur, Luis (2001): El Conflicto Amazónico: 1932-1934, 2001

Campbell, Lyle (1997): American Indian languages: the historical linguistics of Native America. Oxford: Oxford University Press

Candioti, Marcial R. (1920): Bibliografía doctoral de la Universidad de Buenos Aires: y catálogo cronológico de las tesis en su primer centenario 1821-1920 (Buenos Aires, Talleres Gráficos); 
Artigo original

Hegemonia - Revista Eletrônica de Relações Internacionais do Centro Universitário Unieuro

ISSN : $1809-1261$

UNIEURO, Brasília, número Especial, 2016, pp. 121-174.

Cardona Tobón, Alfredo (2011): Tomás Funes y los Caucheros del Orinoco. El Caño Casiquiare: una ruta de ignominia, Historia y región, 15 de agosto de 2011;

Cardoso de Mello, Louise (2015): De Cayarí a Madeira: Procesos históricos de etnogénesis en el suroeste amazónico durante el período colonial, Memorias, Revista Digital de Historia y Arqueología desde el Caribe Colombiano (Barranquilla), n.26;

Carod-Artal, F. J. y C.B. Vázquez-Cabrera (2001): Antropología neurológica entre los indios Kamayurá del Alto Xingú, Revista Neurologica, 2001; 32:688-695

Carvalho, Regina de (2006): Museo Maguta de la Tribu Tikuna, en Patrícia Melo Sampaio y Regina de Carvalho Retal, eds. Rastros da Memória. Histórias e trajetórias das populações indígenas na Amazônia (Manaos: Universidade Federal do Amazonas, 2006).

Carvalho Vieira, Bianca; André Salgado; y Leonardo Santos (2015): Landscapes and Landforms of Brazil (World Geomorphological Landscapes)

Casaccia, Gladys (2008): La reivindicación territorial de los Ayoreo Totobiegosode en el Chaco Paraguayo, ponencia presentada en el IX Congreso Argentino de Antropología Social "Fronteras de la Antropología", Posadas, Argentina. Mesa: Sociedades Indígenas y Estados Nacionales

Casas Mendoza, Carlos Alberto (2012): Modernización, territorio y políticas indigenistas: Isla do Bananal (Mato Grosso, Brasil) y Los Altos 
Artigo original

Hegemonia - Revista Eletrônica de Relações Internacionais do Centro Universitário Unieuro

ISSN: $1809-1261$

UNIEURO, Brasília, número Especial, 2016, pp. 121-174.

de Chiapas (México), entre 1940 y 1960, Relaciones (Zamora) vol.33 no.130 Zamora ene. 2012;

Casco, Sylvina Lorena; Matías Neiff; y Juan José Neiff (2005): Biodiversidad en ríos del litoral fluvial. Utilidad del software PULSO, en Temas de la Biodiversidad del litoral fluvial argentino, II INSUGEO, Miscelánea, 14: 419-434;

Castaño-Uribe, Carlos (2008): Tradición Cultural Chiribiquete, en Rupestreweb, http://www.rupestreweb.info/chiribiquete2.html

Castilla C., Oscar; Nelly Luna Amancio y Fabiola Torres López (2015): Oro sucio: la pista detrás del London Bullion Market, OjoPúblico;

Castillo Rodríguez, Miguel E. (2013). Los ríos de montaña: grandes mensajeros de los cambios tectónicos y climáticos. Ciencias 107-108, julio 2012-febrero 2013, 80-85. [En línea]

Castro Pereira, Márcia Leila de (2009): "Rios de História": Guerra, Tempo e Espaco entre os Mura do Baixo Madeira (AM), Tese apresentada ao Programa de Pós-Graduação em Antropologia Social do Instituto de Ciências Sociais, Departamento de Antropologia da Universidade de Brasília, como requisito parcial à obtenção do título de Doutora em Antropologia.

Castro Suárez, Jesús (2013): De Aislados a Refugiados por Operaciones Petroleras: El Caso de los Mashco-Piros del Parque Nacional del Manu, Director de ECODESS 
Artigo original

Hegemonia - Revista Eletrônica de Relações Internacionais do Centro Universitário Unieuro

ISSN: $1809-1261$

UNIEURO, Brasília, número Especial, 2016, pp. 121-174.

Cavalcante Gomes, Denise Maria (2014): Imágenes de las sociedades contra el estado en la Amazonia antigua, en Marcelo Campagno, ed. Pierre Clastres y las sociedades antiguas (Miño y Dávila Editores), 81-100;

Cayón, Luis (2002): En las aguas de Yuruparí: cosmología y chamanismo makuna (Bogotá: ediciones uniandes);

Cayón, Luis (2008): "Ide ma, el camino de agua. Espacio, chamanismo y persona entre los makuna", en: Antípoda Revista de Antropología y Arqueología, N.o 7, julio-diciembre, Universidad de Los Andes, Bogotá, pp. 141-173;

Cayón, Luis (2009): La persona makuna. Más allá del interior y el exterior, en: Boletín de Antropología Universidad de Antioquia, Vol. 23, N.o 40, pp. 279-300;

Cayón, Luis (2012): Gente que come gente: a propósito del canibalismo, la caza y la guerra en la Amazonía, Maguaré, Vol 26, Iss 2, Pp 19-49;

Cayón, Luis (2013): Pienso, luego creo: la teoría makuna del mundo (Bogotá: Instituto Colombiano de Antropología e Historia)

Cerón Martínez, Carlos Eduardo y Consuelo Montalvo Ayala (1998): Etnobotánica de los huaorani de quehueiri-ono, Napo-Ecuador (Quito: Editorial Abya Yala);

Cerveira de Sena, Ernesto (2013): Fugas e reescravizações em região fronteiriça 
Artigo original

Hegemonia - Revista Eletrônica de Relações Internacionais do Centro Universitário Unieuro

ISSN: $1809-1261$

UNIEURO, Brasília, número Especial, 2016, pp. 121-174.

Estudos Ibero-Americanos, PUCRS, v. 39, n. 1, p. 82-98, jan./jun. 2013

Chambouleyron, Rafael (2010): Povoamento, Ocupação e Agricultura na Amazônia Colonial Amazonia (1540-1706), (Belém: Editora Acaí);

Chambouleyron, Rafael (2014): "Como se hace en Indias de Castilla". El cacao entre la Amazonia portuguesa y las Indias de Castilla (siglos XVII y XVIII), Revista Complutense de Historia de América, v.40, 23-43;

Chaparro Amaya, Adolfo (2013): Pensar caníbal. Una perspectiva amerindia de la guerra, lo sagrado y la colonialidad (Buenos Aires: Katz Editores)

Chaparro Ortiz de Zevallos, Anahí (2008): Los yagua en el contexto del turismo étnico.

La construcción de la cultura para el consumo en el caso de Nuevo Perú, Anthropologica/Año XXVI, N.o 26, diciembre de 2008, pp. 113-142 113

Chase-Sardi, Miguel (1990): Situación sociocultural, económica, jurídicopolítica actual de las comunidades indígenas del Paraguay. Centro Interdisciplinario de Derecho Social y Economia Política, Universidad Católica, Asunción.

Chaumeil, Jean-Pierre (1981): Historia y migraciones de los yagua.Lima, Peru: Centro Amazónico de Antropología y Aplicación Práctica "serie antropológica 3 
Artigo original

Hegemonia - Revista Eletrônica de Relações Internacionais do Centro Universitário Unieuro

ISSN: $1809-1261$

UNIEURO, Brasília, número Especial, 2016, pp. 121-174.

Chaumeil, Jean-Pierre (1983): Ver, saber, poder. El chamanismo de los Yagua de la Amazonía Peruana Paris: Editions de l'Ecole des Hautes Etudes en Sciences Sociales "Recherches d'histoire et de sciences sociales

Chaumeil, Jean-Pierre (1994): Una visión de la Amazonía a mediados del siglo XIX: el viajero Paul Marcoy, en: Bulletin de I'Institut Francais d'Ètudes Andines, Lima, 1994, tomo 23, No 2

Chaumeil, J. P. (1997): Les os, les flûtes, les morts. Mémoire et traitement funéraire en Amazonie, Journal de la Société des Américanistes Année 1997, Volume 83, Numéro 83, pp. 83-110;

Chaumeil, Jean-Pierre (2009): El comercio de la cultura: el caso de los pueblos amazónicos

Bulletin de I'Institut Français d'Études Andines / 2009, 38 (1): 61-74

Chaumeil, Bonnie y J. P. Chaumeil (2004): El tío y el sobrino. El parentesco entre los seres vivos según los Yagua, en Alexandre Surrallés, y Pedro García Hierro, ed., Tierra Adentro. Territorio indígena y percepción del entorno, IWGIA, 83-96;

Chaves Ch., Margarita y Juan José Vieco A. (1987): Indígenas del Alto Putumayo-Caquetá, en: Introducción a la Colombia Amerindia. Instituto Colombiano de Antropología (Bogotá),

Chibnik, Michael (1991): Quasi-Ethnic Groups in Amazonia, Ethnology, Vol. 30, No. 2 (Apr., 1991), pp. 167-182 
Artigo original

Hegemonia - Revista Eletrônica de Relações Internacionais do Centro Universitário Unieuro

ISSN: $1809-1261$

UNIEURO, Brasília, número Especial, 2016, pp. 121-174.

Chirif, Alberto (2012): El Libro Azul Británico de Roger Casement sobre el Putumayo, en La fiebre del caucho y los crímenes del Putumayo, Boletín temático Servindi (Lima, Perú), n.67

Chuecas Cabrera, Adda (1996): "El pueblo Yagua y su lucha por sobrevivir"; Derechos humanos y pueblos indígenas de la Amazonía peruana: realidad, normativa y perspectivas: 193-224. Lima: APEPCAAAP

Cipolletti, María Susana (2013): Dos escritos inéditos del jesuíta Pablo Maroni sobre el Noroeste amazónico (indígenas Encabellados, Tucano, 1739-40), Jahrbuch für Geschichte Lateinamerikas. Volume 36, Issue 1, Pages 151-172

Clarke, Mike (2009): Waterways between East and West Europe: A History to 1930

Clastres, Pierre (1962): "Echange et pouvoir: philosophie de la chefferie indienne," L'Homme II: 1, 1962, pp.51-65.

Clastres, Pierre (1974): La societé contre I'état: Recherches d'anthropologie politique, Paris, Les Editions de minuit, 1974/2011, p. 161-186.

Clastres, Pierre (1977, 2013): Archéologie de la violence (Paris: Editions de l'Aube); 
Artigo original

Hegemonia - Revista Eletrônica de Relações Internacionais do Centro Universitário Unieuro

ISSN: $1809-1261$

UNIEURO, Brasília, número Especial, 2016, pp. 121-174.

Clastres, Pierre (2009): La sociedad contra el estado (Buenos Aires: Caronte);

Clavero, Bartolomé (2011): Nación y naciones en Colombia entre constitución, concordato y un convenio (1810-2010), Revista de historia del derecho, no.41 Ciudad Autónoma de Buenos Aires ene./jun. 2011

Cleary, David (1990): Anatomy of the Amazon Gold Rush (Iowa City: University of Iowa);

Cleary, David (2001): Towards an environmental history of the Amazon: From prehistory to the nineteenth century, Latin American Research Review, 36, 2, 65ff.

Coelho Jaeger, Bruna \& Bernardo Jurado Pretes (2013): A EstratégiaInfraestrutural da Integração Sul-Americana: a geopolítica doEixoInteroceânico Central, Seminario Brasileiro de Estudos Estratégicos Internacionales (SEBREII)

Cohn, Clarice, José Glebson Vieira, Leandro Mahalem de Lima, Renato Sztutman y Rose Satiko Gitirana Hikiji (2007): Por que canta Anthony Seeger?, Revista Antropologica, vol.50 no.1 São Paulo Jan./June 2007

Combés, Isabelle (2005): Etno-historias del Isoso. Chané y Chiriguanos en el Chaco boliviano (siglo XVI al XX), La Paz IFEA/PIEB,

Combés, Isabelle (2005): Las batallas de Kuruyuki. Variaciones sobre una derrota chiriguana, Bulletin de I'Institut Français d'Études Andines, 20 (1): 237-251; 
Artigo original

Hegemonia - Revista Eletrônica de Relações Internacionais do Centro Universitário Unieuro

ISSN: $1809-1261$

UNIEURO, Brasília, número Especial, 2016, pp. 121-174.

Combés, Isabelle (2010): ¿Indios y Blancos? Hacer (Etno) Historia en las Tierras Bajas de Bolivia, Boletín Americanista, Año LX.1, no 60, Barcelona, 2010, pp. 15-32,

Combés, Isabelle; Diego Villar; y Kathleen Lowrey (2009): Comparative Studies and the South American Gran Chaco, Tipití, Journal of the Society for the Anthropology of Lowland South America, v.7, issue 1, article 3;

Comisión Andina de Juristas (2009): Estado de la relación entre justicia indígena y justicia estatal en los países andinos. Estudio de casos en Colombia,Perú, Ecuador y Bolivia (Lima: Comisión Andina de Juristas, 2009);

Conklin, Beth A. (2005): Cosmologia Canibal: Dinámicas de Oposición y Amistad en las Fiestas de la Amazonia, Boletín de Arqueología (PUCP), n.9, 45-66;

Conklin, Beth A. y Laura R. Graham (2009): The Shifting Middle Ground: Amazonian Indians and Eco-Politics

Contreras Roqué, Julio Rafael (2008): Guido Boggiani, 1861-1901 : entre la memoria y el olvido /..[Buenos Aires] : Historia Natural "Félix de Azara"

Cooper, Martin (2011): Brazilian Railway Culture, Cambridge Scholars Publishing 
Artigo original

Hegemonia - Revista Eletrônica de Relações Internacionais do Centro Universitário Unieuro

ISSN: $1809-1261$

UNIEURO, Brasília, número Especial, 2016, pp. 121-174.

Córdoba, Lorena I. (2012a): "El boom cauchero en la Amazonía boliviana: encuentros y desencuentros con una sociedad indígena (1869-1912)", en Diego Villar \& Isabelle Combès (eds.), Las tierras bajas de Bolivia: miradas históricas y antropológicas. Santa Cruz de la Sierra: El País / Museo de Historia UAGRM, págs. 125-156.

Córdoba, Lorena I. (2012b): Misioneros-Patrones e IndígenasSiringueros: el caucho entre los Chácobos del Beni (Siglo XX), Boletín Americanista, año LXII, 2, n.o 65, Barcelona, 2012, págs. 85-106,

Córdoba, Lorena I. (2014): Los panos bolivianos en el imaginario cauchero (siglos XIX y XX), Caravelle 103, pp. 35-50;

Cordovil, Daniela (2012): Afro-Brazilian religions and audiovisual narratives in Amazonia, Virtual Brazilian Anthropologyvibrant, v.9, n.2

Cornejo Chaparro, Manuel (2010): Sir Roger Casement. El visitante de las tinieblas, Diario El Comercio. Viernes, 14 de Septiembre del 2010

Couly, Claire (2013): Perception des végétaux chez les Ribeirinhos d'Amazonie brésilienne », Revue d'ethnoécologie [En ligne], 3 | 2013, mis en ligne le 19 novembre 2013,

Couto, Jorge (2007): O poder temporal nas aldeias de indios do estado do Grao-Pará e Maranhao no periodo pombalino: foco de conflitos entre os jesuitas e a coroa (1751-1759). Cultura portuguesa na ilha de Santa Cruz (Lisboa: Estampa), 53-77; 
Artigo original

Hegemonia - Revista Eletrônica de Relações Internacionais do Centro Universitário Unieuro

ISSN : $1809-1261$

UNIEURO, Brasília, número Especial, 2016, pp. 121-174.

D'Angelo, Biagio y Maria Antonieta Pereira, orgs. (2007): Un Río de

Palabras. Estudios sobre literatura y cultura de la Amazonia, Lima: Fondo Editorial de la Universidad Católica Sedes Sapientiae

Davidson, William V. (2014): Recent Ethnogeography on Historic Latin America

Davis E.W., y Yost J.A. (1983): The ethnomedicine of the Waorani of Amazonian Ecuador, J Ethnopharmacol. 1983 Dec; 9 (2-3): 273-97.

Davis, Edmund Wade (1953): El río, exploraciones y descubrimientos en la selva amazónica (Coleccion Tierra Firme, Serie Continente Americano)

Davis, Harold Eugene; John J. Finan, y F. Taylor Peck (1977): Latin American Diplomatic History: An Introduction (Louisiana State University);

Davis, W. M. (1899): "The Geographical Cycle", en The Geographical Journal, vol.

14, pp. 481-504.

Dean, Bartholomew y Jerome M. Levi (2003): At the Risk of Being Heard: Identity, Indigenous Rights, and Postcolonial States, Ann Arbor: The University of Michigan Press

Del Cairo Silva, Carlos Luis (2003): Analogía, Mito y Ritual: perspectivas sobre el Yurupari, Virajes (Caldas), Vol. 2 No. 1, Pag. 164-185; 
Artigo original

Hegemonia - Revista Eletrônica de Relações Internacionais do Centro Universitário Unieuro

ISSN: $1809-1261$

UNIEURO, Brasília, número Especial, 2016, pp. 121-174.

Descola, Philippe (1988): La chefferie amérindiennedans l'anthropologie politique. Revue française de science politique, Année 1988

Descola, Philippe (2012): Más allá de naturaleza y cultura, Buenos Aires, Amorrortu editores, 624 págs., 2012

Desmarchelier, Cristian; Mongelli, Elena; Coussio, Jorge Daniel; Giulietti, Ana María; y Ciccia, Graciela (1995): Etnobotánica y bioactividad de plantas medicinales utilizadas por un grupo indígena Takana de la Amazonia peruana

Deus, José Antônio Souza de (2008): O etnoambientalismo e as novas territorialidades indígenas em curso no contexto regional da Amazônia meridional e oriental, Caderno de Geografia, Belo Horizonte, v. 18, n. 29, p. $59-82,2^{\circ}$ sem. 2008

Deus, José Antônio Souza de (2009): Etnogeografía e Dinamica da "Fronteira": Novas Territorialidades Indígenas e Sustentabilidade Cultural dos Povos Aruak das Rain-Forests na Amazonia Ocidental, en: ENCUENTRO DE GEÓGRAFOS DE AMÉRICA LATINA, 12, Montevidéu, 2009. Anais....Montevidéu, 2009, p. 1-16

Deus, José Antônio Souza de, Ludimila de Miranda Rodrigues y Liliane de Deus Barbosa

(2010): Processos de Desterritorializacao e Reterritorializacao de Sociedades Indígenas na Área Xinguana e Entorno- Amazonia Meridional/Brasil 
Artigo original

Hegemonia - Revista Eletrônica de Relações Internacionais do Centro Universitário Unieuro

ISSN: $1809-1261$

UNIEURO, Brasília, número Especial, 2016, pp. 121-174.

Díaz Ortiz, Jaime Ernesto (2008): Manejo del recurso hídrico en culturas precolombinas, Revista EIDENAR: Ejemplar 7 / Enero - Diciembre 2008

Domínguez, Camilo (1987): Colombia y la Panamazonía, en Colombia Amazónica, Universidad de la Amazonia Colombiana;

Domínguez, Camilo y Augusto Gómez (1994): Nación y etnias: conflictos territoriales en la Amazonía colombiana, 1750-1933. Bogotá: Disloque Editores Ltda., 1994.

Domínguez Ossa, Camilo A. (1975): El Río Apaporis. Visión AntropoGeográfica, Revista Colombiana de Antropología, vol.18, 131-171;

Domingues Teixeira, Marco Antonio (1998): O Comércio e as Rotas Fluviais na Sociedade Guaporeana Colonial, Revista de Educacao, Cultura e Meio Ambiente- Set.-N 13, Vol II, 1998;

Doughty, Caitlin (2010): Crude, Cash and Culture Change: The Huaorani of Amazonian Ecuador, Consilience: The Journal of Sustainable Development, Vol. 4, Iss. 1 (2010), Pp. 18-32

Dourojeanni, Marc (2010): Perú: Hidrovías en la Amazonía del Perú, Servicios en Comunicación Intercultural Servindi, Lima, Perú, 15 de octubre de 2010.

Drumond Mendes Barros, Maria Cândida (2004): A missão Summer Institute of Linguistics e o indigenismo latino-americano: história de uma 
Artigo original

Hegemonia - Revista Eletrônica de Relações Internacionais do Centro Universitário Unieuro

ISSN : $1809-1261$

UNIEURO, Brasília, número Especial, 2016, pp. 121-174.

aliança (décadas de 1930 a 1970), Rev. Antropol. vol.47 no.1 São Paulo 2004;

Dugan, Patrick J. (1992): Conservación de humedales: un análisis de temas de actualidad y acciones necesarias (IUCN);

Durán Coirolo, Alicia y Roberto Bracco Boksar, ed. (2000): Lomas de Ocupación en los Llanos de Moxos, en Arqueología de las Tierras Bajas (Montevideo, Uruguya: Comisión Nacional de Arqueología), 207-226;

Echeverri, Juan Alvaro (2004): Territorio como cuerpo y territorio como naturaleza: ¿diálogo intercultural?, en Alexandre Surrallés, y Pedro García Hierro, ed. Tierra Adentro. Territorio indígena y percepción del entorno, IWGIA, 259ff.

Edmundson, George ed. (1922): Journal of the travels and labours of Father Samuel Fritz in the River of the Amazons between 1686 and 1722 (London: Hakluyt Society);

Eloy, Ludivine, Anna Greissing, Florent Kohler, François-Michel Le Tourneau, Stephanie Nasuti, Sophie Caillon, y Guillaume Marchand (2008): Géographie et anthropologie: deux regards complémentaires pour l'étude des territoires des populations traditionnelles d'Amazonie brésilienne, Revue franco-brésilienne de géographie/Revista francobrasileira de geografía, Cybergeo : European Journal of Geography, EchoGéo, Pôle de recherche pour l'organisation et la diffusion de l'information géographique (CNRS), 2008, pp.1-12 
Artigo original

Hegemonia - Revista Eletrônica de Relações Internacionais do Centro Universitário Unieuro

ISSN: $1809-1261$

UNIEURO, Brasília, número Especial, 2016, pp. 121-174.

Emkow, Carola (2012). Araona, en: Mily Crevels y PieterMuysken (eds.) Lenguas de Bolivia, tomo II Amazonía. La Paz: Plural editores (en prensa)

Epps, Patience L. (2005): Language endangerment in Amazonia:the role of missionaries, In Jan Wohlgemuth; Tyko Dirksmeyer (Ed.), Bedrohte Vielfalt: Aspekte des Sprach(en)tods = Aspects of language death (pp. 311-327). Berlin [u.a.]: Weißensee-Verl.

Erickson, Clark L. (2000): Lomas de Ocupación en losLlanos de Moxos, en Alicia Durán Coirolo y Roberto Bracco Boksar, editores, Arqueología de las Tierras Bajas, Comisión Nacional de Arqueología, Montevideo, Uruguay, pp. 207-226.

Erickson, Clark L.; Alvarez, Patricia; ySergio Calla (2008): "Zanjas Circundantes: Obras de Tierra Monumentales de Baures en la Amazonia Bolivia", Department of Anthropology Papers.Paper 11. http://repository.upenn.edu/anthro_papers/11

Eriksen, Love (2011): Nature and Culture in Prehistoric Amazonia. Using G.I.S. to reconstruct ancient ethnogenetic processes from archaeology, linguistics, geography, and ethnohistory, printed in Sweden by MediaTryck, Lund University

Escobar, Ticio (2007): The Curse of Nemur. In Search of the Art, Myth, and Ritual of the Ishir. Pittsburgh, PA: University of Pittsburgh Press, 2007

Espinosa de Rivero, Oscar (1998): Los pueblos indígenas de la amazonía peruana y el uso político de los medios de comunicación, en 
Artigo original

Hegemonia - Revista Eletrônica de Relações Internacionais do Centro Universitário Unieuro

ISSN: $1809-1261$

UNIEURO, Brasília, número Especial, 2016, pp. 121-174.

América Latina Hoy: Revista de Ciencias Sociales (Instituto de Iberoamérica de la Universidad de Salamanca);

Esvertit Cobes, Natalia (2001): Los imaginarios tradicionales sobre el oriente ecuatoriano, Revista de Indias, 61 (223), 541-571;

Everett, Daniel L. (2014): No duermas, hay serpientes: vida y lenguaje en la Amazonia (Madrid: Turner Publicaciones);

Faoro, Raymundo (1967): Os Donos do Poder. Formacao do Patronato Politico Brasileiro;

Faulhaber, Priscila (2010): Curt Nimuendajú, Etnografía Ticuna e frontera amazónica, tesis de maestría

Fausto, Carlos (2015): Warfare and Shamanism in Amazonia (Cambridge Latin American Studies)

Fausto, Carlos y Michael Heckenberger, ed. (2007): Time and Memory in Indigenous Amazonia Anthropological Perspectives (University Press of Florida);

Favaro Martins, Marcos Antonio (2011): Mario Travassos e Mario Badia Malagrida: dois modelos geopolíticos sobre a América do Sul.Dissertacaodefendida no Prolamemabrilde 2011;

Favaron, Pedro (2011): "Llamando a los espíritus: Cantos sagrados de la Amazonía". Tinkuy. Boletín de investigación y debate, 16: 149-167 
Artigo original

Hegemonia - Revista Eletrônica de Relações Internacionais do Centro Universitário Unieuro

ISSN: $1809-1261$

UNIEURO, Brasília, número Especial, 2016, pp. 121-174.

Fearnside, P.M. (2014): Brazil's Madeira River dams: A setback for environmental policy in Amazonian development. Water Alternatives 7(1): 156-169.

http://www.water-

alternatives.org/index.php/alldoc/articles/vol7/v7issue1/244-a7-115/file

Fearnside, P.M. \& A.M.R. Figueiredo (2015): China's influence on deforestation in

Brazilian Amazonia: A growing force in the state of MatoGrosso. BU Global Economic Governance Initiative Discussion Papers 2015-3, Boston University, Boston, Massachusetts, U.S.A. 51 pp.

http://www.bu.edu/pardeeschool/files/2014/12/Brazil1.pdf

Ferguson, R. Brian (1990): Blood of the Leviathan: Western contact and warfare in Amazonia, American Ethnologist, 17 (2);

Fernández, Gustavo (2015): El debate sobre El abrazo de la serpiente: ¿hacia un espectador emancipado? , blog Pajarera del Medio

Fernández, María del Rosario y Rodolfo Raúl Hachén (2007): Incidencia de la cosmovisión qom (toba) en las técnicas etnobotánicas de recolección, en $\mathrm{V}$ Congreso Europeo CEISAL de Latinoamericanistas Bruselas (2007) / Abril 11 - 14, Simposio ET / DH - 8: Pueblos Indígenas, Plantas y Mercados Nuevos Enfoques Antropológicos y Etnobotánicos 
Artigo original

Hegemonia - Revista Eletrônica de Relações Internacionais do Centro Universitário Unieuro

ISSN: $1809-1261$

UNIEURO, Brasília, número Especial, 2016, pp. 121-174.

Fernández Arrillaga, Inmaculada y Mar García Arenas (2009): Dos Caras de una misma expulsion: el destierro de los jesuitas portugueses y la reclusion de los misioneros alemanes, Hispania Sacra, LXI, 227-256;

Fernandes de Sousa Neto, Manoel (2012): Planos para o Império: os planos de viação do Segundo Reinado (1869-1889), São Paulo: Alameda;

Fernández Espinosa, Marta Lucía (2012): Amazonas un país de caníbales y FARC, La Pluma, martes 8 de mayo de 2012;

Ferreira, Mário Clemente (2007): O Mapa das Cortes e o Tratado de Madrid: a cartografia a serviço da diplomacia, Varia hist. vol.23 no. 37 Belo Horizonte Jan./June 2007;

Ferreira Glielmo, Gustavo (2007): Ocaso do poder jesuítico na Amazônia, Univ. FACE, Brasília, v. 4, n. 1/2, p. 187-203, jan./dez. 2007;

Ferreira Glielmo, Gustavo (2010): O projeto português para a amazônia e a companhia de jesus (1751-1759): reflexos do confronto entre absolutismo ilustrado e poder religioso na América equinocial. 2010. 230 f.

Ferrer Benimeli, José A. (2009): La expulsión de los jesuitas de las misiones del Amazonas (1768-1769) a través de Pará y Lisboa, Biblioteca Virtual Miguel de Cervantes 
Artigo original

Hegemonia - Revista Eletrônica de Relações Internacionais do Centro Universitário Unieuro

ISSN: $1809-1261$

UNIEURO, Brasília, número Especial, 2016, pp. 121-174.

Figueroa, Mary (1986): Misioneros, indígenas y caucheros región del Caquetá-Putumayo (Siglo XVI-XIX), Tesis de antropología, Universidad Nacional

Finneran, Niall (2009): Water and the Construction of Social and Religious Identities in West Africa: An Archaeological Perspective, en Oestigaard, Terje ed. (2009): 189-213

Fleck, David W. (2007): Did the Kulinas become the Marubos? A Linguistic and Ethnohistorical Investigation, Tipití: Journal of the Society for the Anthropology of Lowland South America, v.5, issue 2, article 2;

Follér, Maj-Lis (1999): Ethnic groups and the globalization ProcessReflections on the Amazonian groups of Peru from a human ecological perspective, Human Ecology 25(4):545-566;

Fonseca, Dayz Peixoto (2008): O Viajante Hércules Florence: águas, guanás e guaranás, (Campinas, SP: Pontes);

Fonseca Gadelha, Regina Maria A. (2002): Conquista e ocupação da Amazônia: a fronteira Norte do Brasil, Estudos Avancados, v.16, n.45,

Fontaine, Laurent (2014): La nuit pour apprendre. Le chamanisme nocturne des Yucuna d'Amazonie colombienne (Société d'ethnologie) / Revue Civilisations, Vol. $62, \mathrm{n}^{\circ} 1$ et 2 Dossier Identité, culture et intimité

Foot Hardman, Francisco (1988) : O trem fantasma (A modernidade na selva) (Sao Paulo : Companhia das Letras); 
Artigo original

Hegemonia - Revista Eletrônica de Relações Internacionais do Centro Universitário Unieuro

ISSN: $1809-1261$

UNIEURO, Brasília, número Especial, 2016, pp. 121-174.

Foresta, Ronald A. (1992): Amazonia and the politics of geopolitics.Geographical Review 82(2), 128-142.

Frank da Costa, Joao (1968): Joaquim Nabuco e a política exterior do Brasil (Rio de Janeiro: Grafica Record Editora);

Franky Calvo, Carlos Eduardo (2001): Ordenamiento Territorial Indígena Amazónico: aportes desde la diversidad al Estado-nación colombiano, en: Franky, C. \& Zárate, C. (ed.) Imani mundo. Studios en la Amazonia colombiana. Bogotá: Unibiblos. pp.71-104.

Freitas, Jorge Manuel de Costa. (2004): A escola geopolítica brasileira. Rio de Janeiro: Biblioteca doExército Ed., 2004.

Gallart, Horacio (1947): CruzandolaAméricadelSuddesdeelRíode laPlatahastael Orinoco, por vía fluvial, Revista Geográfica Americana, No 169, año XV, Octubre de 1947

Gallois, Dominique Tilkin (2002): Ilustrações: índios Wajãpi. Kusiwa: pintura corporal e arte gráfica wajãpi, Rio de Janeiro, Museu do ÍndioFUNAI/APINA/CTI/NHII-USP, 2002. 72 pp

Garay Vera, Cristián (2008): El Acre y los "Asuntos del Pacífico": Bolivia, Brasil, Chiley Estados Unidos, 1898-1909, Historia (Santiago) v.41 n.2 Santiago dic. 2008

Garay Vera, Cristian (2009): El atributo amazónico del Perú. La construcción de una soberanía 1903-1942, Historia Crítica, n.39, 108129; 
Artigo original

Hegemonia - Revista Eletrônica de Relações Internacionais do Centro Universitário Unieuro

ISSN: $1809-1261$

UNIEURO, Brasília, número Especial, 2016, pp. 121-174.

Garcia, R. A.; Soares-Filho, B. S.; Sawyer, D. O. (2007): Socioeconomic dimensions, migration, and deforestation: an integrated model of territorial organization for the Brazilian Amazon. Ecological Indicators, v. 7, n. 3, p. 719-730, 2007

García Charría, Wilealdo (2002): Planificación de Cuencas Hidrográficas bajo la perspectiva de los sistemas complejos. Medellín. Tesis Posgrado (Especialista en Gestión Agroambiental). Universidad Nacional deColombia, Sede Medellín. Facultad de Ciencias Humanas.

García Charria, Wilealdo

(2011):

EISistemaComplejodelaCuencaHidrográfica

García Jordán, Pilar (2001): En el Corazón de las Tinieblas... del Putumayo,

1890-1932. Fronteras, Caucho, Mano de Obra Indígena y Misiones

Católicas en

la Nacionalización de la Amazonía, Revista de Indias, 2001, vol. LXI, núm. 223

R. I., 2001, n. 0223

García Jordán, Pilar (2005): La Cueva, la Liga y el escándalo del Putumayo. A propósito de redes sociales, económicas y políticas en la Iquitos de inicios del siglo XX, En Estudios sobre América, siglos XVI-XX, Asociación Española de Americanistas, Sevilla, 2005, pp. 1609-1624;

García Jordán, Pilar (2006): Frontera, espacio y Estado. Un estudio de caso: la Bolivia republicana, en Montserrat Ventura i Oller, Ariadna Lluís i 
Artigo original

Hegemonia - Revista Eletrônica de Relações Internacionais do Centro Universitário Unieuro

ISSN: $1809-1261$

UNIEURO, Brasília, número Especial, 2016, pp. 121-174.

Vidal-Folch, y Gabriela Dalla Corte, editoras La frontera entre límits i ponts (Barcelona. Editorial, Casa Amèrica Catalunya), 21-36.

García-Morcillo, Juan (1982): Del caucho al oro: El proceso colonizador de Madre de Dios, Revista española de antropología americana, vol. XII. Ed. Univ. Complutense. Madrid

Gasché, Jurgen (1999): Las comunidades nativas, entre la apariencia y la realidad: El ejemplo de las comunidades huitoto y ocaina del río Ampiyacu, Amazonia Indígena, año 3, n.5, 11-31;

Gayubas, Augusto (2012): Pierre Clastres y las sociedades contra el Estado, Germinal. Revista de Estudios Libertarios; Madrid; p. 17-30;

Gemaque Souza, Charles Benedito (2014): Geopolitica na Pan-Amazonia: Territorios, fronteiras e identidades, Revista GeoAmazonia, n.2, v.01, 5984;

Genest, Serge (1978): Introduction à l'ethnomédecine. Essai de synthèse, Anthropologie et Societés, v.2, n.3, 5-28;

Gilbert, G. K. (1880): Geology of Henry Mountains. Government Printing Office, eua.

Gómez, Augusto y Camilo Domínguez (2011): Caminos y varadores de la Amazonía, quinerías y caucherías del Amazonas 
Artigo original

Hegemonia - Revista Eletrônica de Relações Internacionais do Centro Universitário Unieuro

ISSN: $1809-1261$

UNIEURO, Brasília, número Especial, 2016, pp. 121-174.

Gómez Cerezo, Rosa (2003): Modelos Conceptuales de Funcionamiento de Ríos y Arroyos (inédito);

Gómez J., Carlos Mario (2013): John Brown va hacia donde nace el sol, El Colombiano, 23 de noviembre de 2013;

Gómez López, Augusto Javier (2014): Putumayo : la vorágine de las caucherías : memoria y testimonio, Bogotá : Centro Nacional de Memoria Histórica, 2014.

Gomez-Imbert, Elsa (2011): Testimonio de una lingüista de campo en Amazonía

Goodman, Jordan (2010): "The Devil and Mr. Casement,"

Gómez - García Krust, Vannya (2010): Historia de los Mosetenes de Asunción del Quiquibey;

Gómez-Quintero, Juan David (2009): La idea de Colombia en el periodismo literario de Germán Castro-Caycedo; una lectura sociológica, Actas I Congreso Internacional Latina de Comunicación Social: La Laguna, Tenerife, miércoles, 9 a viernes, 11 de diciembre de 2009 / coord. por José Manuel de Pablos Coello, 2009

Gottgens, Johan F. (2000): The Paraguay-Parana Hidrovia: Large-scale Channelization or a "Tyranny of Small Decision", Excerpts from the full paper presented in the uncorrected, advance proof of The Pantanal of 
Artigo original

Hegemonia - Revista Eletrônica de Relações Internacionais do Centro Universitário Unieuro

ISSN: $1809-1261$

UNIEURO, Brasília, número Especial, 2016, pp. 121-174.

Brazil, Bolivia and Paraguay, Hudson MacArthur Publishers, copyright 2000 by Waterland Research Institute.)

Gow, Peter (2001): An Amazonian myth and its history, Oxford University Press, coll. «Oxford studies in social and cultural anthropology », Oxford, 2001

Gow, Peter (2006): "Purús Song": Nationalization and Tribalization inSouthwestern Amazonia, Tipití: Journal of the Society for the Anthropology of Lowland South America, 4, 271-294;

Grández Alejos, Haydeé (2007): Identidad guayacha: el arte textil en la provincia de Rodríguez de Mendoza (Amazonas, Perú), en D’Angelo, Biagio y Maria Antonieta Pereira, orgs. (2007): Un Río de Palabras. Estudios sobre literatura y cultura de la Amazonia, Lima: Fondo Editorial de la Universidad Católica Sedes Sapientiae, 209-228;

Grandin, Greg (2009) : Fordlandia: The Rise and Fall of Henry Ford'sForgotten Jungle City. New York: Metropolitan Books

Granger, S. (2012): La Guyane et le Brésil, ou la quète d'integration continentale d'un department francais d'Amérique (Paris: Thèse de doctorat de geographie, Université Paris-III);

Gray, Andrew (1996): The Arakmbut of Amazonian Peru, vol. I: Mythology, Spirituality, and History (Oxford: Berghahn Books); 
Artigo original

Hegemonia - Revista Eletrônica de Relações Internacionais do Centro Universitário Unieuro

ISSN: $1809-1261$

UNIEURO, Brasília, número Especial, 2016, pp. 121-174.

Gray, Andrew (1997): The last Shaman--change in an Amazonian community/.Providence, R.I. : Berghahn Books, 1997

Gray, Mark Allan (1996): The International Crime of Ecocide, California Western International Law Journal: Vol. 26: No. 2, Article 3

Greever, Janet Groff (1987): Jose Ballivian y el oriente boliviano. Traduccion, prologo, y notas de Jose Luis Roca. La Paz: Empresa Editora Siglo, 1987

Grenand, F. (2012): Enjeux de territoires sur une frontière méconnue. Entre la France et le Brésil: le fleuve Oyapock, Confins, n.16;

Greño Velasco, José Enrique (1972): El Río de la Plata: un espacio fluvial integrado, Revista Derecho de la Integración, Separata, $N^{\circ} 11$, October 1972;

Grisales, Germán (2008): Sin maldad y colmado de frutales. El progreso, la integración y la globalización de una frontera amazónica colombiana, peruana, brasilera y antiguamente quiteña. Abya-Yala, Quito, 2008

Grupioni, Luis Donicete Benzi (2001): Os Povos Indigenas e a Escola Diferenciada: Comentarios Sobre Alguns Instrumentos Juridicos Internacionais, en Luis Donisete Benzi Grupioni, Lux Boelitz Vidal y Roseli Fischmann, Povos Indigenas e Tolerancia-Construindo Praticas de Respeito e Solidaridade (Sao Paulo: Edusp), 87-97; 
Artigo original

Hegemonia - Revista Eletrônica de Relações Internacionais do Centro Universitário Unieuro

ISSN: $1809-1261$

UNIEURO, Brasília, número Especial, 2016, pp. 121-174.

Guamán, Julián (2006): FEINE, la organización de los indígenas evangélicos en Ecuador Editorial Abya Yala, 2006 - Ecuador

Guerra-Turín, Fredy Hugo (2011): Subdivisión del Tiempo Geológico en la Amazonía Peruana, Ciencia Amazónica (Iquitos), 2011, Vol. 1, No. 1, 5158

Gudynas, Eduardo (2005): La nueva geografía amazónica: entre la globalización y el regionalismo, Observatorio del Desarrollo (CLAES);

Guedes, Gilvan, Sandra Costa, y Eduardo Brondízio (2009): Revisiting the hierarchy of urban areas in the Brazilian Amazon: a multilevel approach, Popul Environ 2009 May; 30 (4-5):159-192;

Guerra Flores, Humberto (1995): Estado actual del conocimiento de la pesquería en la amazonía Peruana, Documento Técnico no 11 . Octubre 1995. Iquitos;

Guevara, Willy (2007): "El Suicidio Femenino Aguaruna" 1999- 2006

Guiteras Mombiola, Anna (2010): Los Indígenas Benianos en el acceso a la propiedad de la tierra y la constitución de una sociedad de frontera en la Bolivia republicana, 1842-1915, Boletín Americanista, n.60, 67-89;

Guyot, Mireille (1979): La historía del mar de Danta, el Caqueta. Una fase de la evolución cultural en el Noroeste amazónico, Journal de la Societé des Americanistes, Journal de la Société des Américanistes,Année 1979, Volume 66, Numéro 66, pp. 99-123; 
Artigo original

Hegemonia - Revista Eletrônica de Relações Internacionais do Centro Universitário Unieuro

ISSN: $1809-1261$

UNIEURO, Brasília, número Especial, 2016, pp. 121-174.

Hack, John T. (1960): "Interpretation of erosional topography in humid temperate regions", en American Journal of Science, vol. 258-A, pp. 8097.

Hack, John T. (1960): El río y la forma. Introducción a la geomorfología fluvial

Hadfield, Charles (1986): World canals: inland navigation past andpresent /

Halperín Donghi, Tulio (2005): Historia Contemporánea de América Latina (Editorial Alianza);

Harkin, Michael E. (2003): Feeling and Thinking in Memory and Forgetting: Toward an Ethnohistory of the Emotions, Ethnohistory 50 (2), 261-284;

Harris, Mark (2010): "The Politics of Nativism: Ethnic Prejudice and Political Power in Mato Grosso, 1831-1834,"

Hawke, Rob (2009): The Making of a Legend: Colonel Fawcett in Bolivia, (tesis, Universidad de Essex

Hawthorne, Walter (2010): From Africa to Brazil: culture, identity, and an Atlantic slave trade, 1600-1830. Nova Iorque: Cambridge University Press, 2010 
Artigo original

Hegemonia - Revista Eletrônica de Relações Internacionais do Centro Universitário Unieuro

ISSN: $1809-1261$

UNIEURO, Brasília, número Especial, 2016, pp. 121-174.

Heckenberger, Michael (2001): Estructura, história e transformacao: a cultura xinguana, en B. Franchetto, y M. Heckenberger, coord..Os povos do Alto Xingu: historia e cultura (Rio de Janeiro: UFRJ), 21-62;

Heckman, C. W. (1998): The Pantanal of Poconé: Biota and ecology in the northern section of the world's largest pristine wetland. Kluwer Academic Publishers, The Netherlands.

Hedberg, Anna Sofia (2007): Outside the world: Cohesion and Deviation among Old Colony Mennonites in Bolivia. Uppsala 2007

Hemming, John (1985): Change in the Amazon Basin: The Frontier after a decade of colonisation. Manchester University Press, 1985

Henderson, James J. (2015): La modernización en Colombia: los años de Laureano Gómez, 1889-1965 (Medellín: Editorial Universidad de Antioquia

Hernández Medina, Juan José (2004): Los Menonitas germanoparlantes en Paraguay: su lengua, literatura y forma de vida, Estudios Edición Electrónica: Amazon.es

Herrera Tello, Juan Carlos (2010): Bartolomé Herrera y la Convención Fluvial de 1851, Red Voltaire;

Hianaly Galeano, Juana (2010): Una verdad oculta en la selva. EL PARAÍSO DEL DIABLO. Viaje a la frontera colombo-peruana, en donde se 
Artigo original

Hegemonia - Revista Eletrônica de Relações Internacionais do Centro Universitário Unieuro

ISSN: $1809-1261$

UNIEURO, Brasília, número Especial, 2016, pp. 121-174.

escenificó la ignominia cauchera del siglo XIX y que inspiró 'El sueño del celta', de Mario Vargas Llosa, El Espectador- 29 Dic 2010;

Hidalgo, Juan (2006): Cosmovisión y participación política de los indígenas en el Ecuador, en América Latina: cidade, campo e turismo. Amalia Inés Geraiges de Lemos, Mónica Arroyo, María Laura Silveira. CLACSO, Consejo Latinoamericano de Ciencias Sociales, San Pablo. Diciembre 2006

Hildebrand, Martin von, y Elizabeth Reichel (1987)."Indígenas del MiritíParaná." In Introducción a la Colombia amerindia, edited by François Correa and Ximena Pachón. Bogotá: Instituto Colombiano de Antropología. (ICAN), 135-150;

Hill, Jonathan D. (2009): History, Power, and Identity: Amazonian Perspectives, Acta Historica Universitatis Klaipedensis XIX, Studia Antropologica III, 25-47;

Hill, Jonathan D. (2013): Etnicidade na Amazônia Antiga: reconstruindo identidades do passado por meio da arqueologia, da linguística e da etnohistória, ILHA, v. 15, n. 1, p. 35-69, jan./jun. 2013;

Homan, Joshua E. (2011): Charlatans, seekers, and shamans: the Ayahuasca boom in western Peruvian Amazonia, doctoral thesis of University of Kansas; 
Artigo original

Hegemonia - Revista Eletrônica de Relações Internacionais do Centro Universitário Unieuro

ISSN: $1809-1261$

UNIEURO, Brasília, número Especial, 2016, pp. 121-174.

Hooper , Paul L.; Simon DeDeo, Ann E. Caldwell Hooper, Michael Gurven y Hillard S. Kaplan (2013): Dynamical Structure of a Traditional Amazonian Social Network, Entropy 2013, 15, 4932-4955

Hoorn, C.; F. P. Wesselingh; H. ter Steege; et. al. (2010): Amazonia through time: Andean Uplift, Climate Change, Landscape Evolution, and Biodiversity, Science, v.330, 927-931;

Hoornaert, Eduardo (1990): O breve periodo profetico das Missoes na Amazonia Brasileira (1607-1661), en Eduardo Hoornaert, coord., Historia da Igreja na Amazonia (Petropolis: Vozes/CEHILA), 121-138;

Horn, Carina; Javier Guerrero; Gustavo A. Sarmiento y María A. Lorente (1995): Andean tectonics as a cause for changing drainage patterns in Miocene northern South America, Geology, v.23, n.3, 237-240;

Hornborg, Alf (2010): Mobility and Migration in Indigenous Amazonia: Contemporary Ethnoecological Perspectives, Tipití: Journal of the Society for the Anthropology of Lowland South America, Volume 8 | Issue 1 Article 6

Hornborg, Alf y Jonathan D. Hill (2012): Ethnicity in Ancient Amazonia: Reconstructing Past Identities from Archaeology, Linguistics, and Ethnohistory (Boulder: Univ. Press Colorado);

Hostnig, Rainer y Raúl Carreño Collatupa (2006): Pusharo, un sitio rupestre extraordinario en la selva amazónica de Madre de Dios, Perú, En Rupestreweb, http://rupestreweb2.tripod.com/pusharo.html 
Artigo original

Hegemonia - Revista Eletrônica de Relações Internacionais do Centro Universitário Unieuro

ISSN: $1809-1261$

UNIEURO, Brasília, número Especial, 2016, pp. 121-174.

Hoyuela Jayo, José Antonio (2005): Brasil una construcción hispánica: el papel de la Unión de las Coronas en la definición de un urbanismo ibérico. Actas do primer Simpósio Luso - Brasileiro de Cartografia Histórica. Rio de Janeiro : Servicio de Património da Marinha - ISCTE, 2005.

Hoyuela Jayo, José Antonio (2007): Brasil, una construcción hispánica. [aut. libro] José Antonio Hoyuela Jayo y Manuel C. Teixeira. URBS IBEROAMERICANA, Memoria, Territorio, Lugar y Artificio de las ciudades castellanas y portuguesas entre los tratados de Tordesillas (1494) y San Ildefonso (1777). s.I. : Giroestudio y Terysos, 2007. Inédito.

Hoyuela Jayo, José Antonio (2011): La deconstrucción de las fronteras de Brasil. CEAMA n 8. Almeida (Portugal) : CEAMA, 2011.

Ibáñez, Juan José (2006): Los Nutrientes del Suelo y Las Plantas: Asimilación y Fertilidad;

Ibáñez Bonillo, Pablo (2015): Historia de dos islas: los mitos coloniales de la Isla Brasil y la Isla Guayana, Memorias: Revista Digital de Historia y Arqueología desde el Caribe, no.26 Barranquilla May/Aug. 2015

Ibáñez Montoya, María Victoria (1992): Trabajos cientificos y correspondencia de Tadeo Haenke, Ministerio de Defensa \& Museo Naval, La Expedicion Malaspina, 1789-1794, Tomo 4, Madrid, Barcelona: Lunwerg Editores, 1992 
Artigo original

Hegemonia - Revista Eletrônica de Relações Internacionais do Centro Universitário Unieuro

ISSN: $1809-1261$

UNIEURO, Brasília, número Especial, 2016, pp. 121-174.

Iriondo, Martin y Daniela Kröhling (2009): From Buenos Aires to Santa Fe: Darwin's observations and modern knowledge, Rev. Asoc. Geol. Argent., v.64 n.1, Buenos Aires abr. 2009;

Izikowitz, K.G. (1935): Musical and other Sound Instruments of the South American Indians. A Comparative Ethnographical Study. Gothenburg: Elanders Boktryckeri Aktiebolag.

Jackson, Jean E. (1994): Becoming Indian: The Politics of Tukanoan Ethnicity, en Kay B. Warren and Jean E. Jackson, eds., Indigenous Movements, Self-Representation and the State in Latin America. University of Texas Press Austin, . 2002

Jetté, Christian y Hugo José Suárez, et.al. (2003): La nacionalización de la Amazonia boliviana: un juego cruzado de intereses públicos y privados, en Fernando Calderón Gutiérrez, coord., Informe de Desarrollo Humano en el Norte Amazónico (PNUD), 23-42;

Jiménez, José Miguel (2008): Chico Mendes: Un ángel de la Amazonía

Jiménez Martínez, Ma Jesús (2011): Jorge Juan y la Geodesia de la Ilustración. Visión técnica e histórica desde el siglo XXI http://www.racv.es/files/Jorge_Juan_y_la_Geodesia.pdf).

Jones, Clarence F. (1928): Agricultural Regions of South America (Worcester, 1928);

Journet, Nicolás (1980) "Los Curripacos del río Isana: Economía y Sociedad"; Revista Colombiana de Antropología XXIII: 125-182. Bogotá 
Artigo original

Hegemonia - Revista Eletrônica de Relações Internacionais do Centro Universitário Unieuro

ISSN : $1809-1261$

UNIEURO, Brasília, número Especial, 2016, pp. 121-174.

Justo Guedes, Max. 1997. A cartografia da delimitação das fronteiras do Brasil no século XVIII. [aut. libro] Varios. Cartografia e diplomacia no Brasil do século XVIII. Lisboa : Cordoaria Nacional, 1997.

Kaufman, Terrence (1994): The native languages of South America. In C. Mosley \& R. E. Asher (Eds.), Atlas of the world's languages (pp. 4676).London: Routledge.

Keifenheim, Barbara (1992): Identité et alterité chez les Indiens Pano, Journal de la Societé des Americanistes, 78:2, 79-93

Keller, Héctor Alejandro (2001): Etnobotánica de los guaraníes que habitan la selva misionera (Corrientes)

Keeley, Lawrence H. (1996): War Before Civilization-The Myth of the Peaceful Savage (New York: Oxford University Press);

Kensinger, Kenneth M. (1977): "Cashinahua Notions of Social Time and Social Space", Actes du 42éme Congres International des Américanistes, Paris, v.II

Kensinger, Kenneth M. (2003). "Being a Real Man: In Memory of Grompes," Tipití: Journal of the Society for the Anthropology of Lowland South America: Vol. 1: Iss. 1, Article 6. Available at: http://digitalcommons.trinity.edu/tipiti/vol1/iss1/6

Kohler, Florent (2006): globslisation et communalisation le cas de populations traditionnelles. Des categories et de leur usages dans la 
Artigo original

Hegemonia - Revista Eletrônica de Relações Internacionais do Centro Universitário Unieuro

ISSN: $1809-1261$

UNIEURO, Brasília, número Especial, 2016, pp. 121-174.

construction sociale d' un group de reference, Race, ethnie, communauté, Paris, France;

Kohlhepp, Gerd (2005): Scientific findings of Alexander von Humboldt's expedition into the Spanish-American Tropics (1799-1804) from a geographical point of view An. Acad. Bras. Ciênc. vol.77 no.2 Rio de Janeiro June 2005Komissarov, Boris (1994): Expedição Langsdorff Acervos e Fontes Históricas (Editora UNESP)

Kotscho, R. (1981): O Massacre Dos Posseiros: Conflicto de Terras no Araguaia-Tocantins. Brasiliense, Sao Paulo;

Kucinski, Bernardo (1978): La Amazonia y la geopolítica del Brasil, en Revista Nueva Sociedad 37, Julio - Agosto 1978, 26-30;

\section{Labate, Bia (2009): Chamanismo y Ciencia en la Alta Amazonía peruana}

\section{Lagos, Ovidio (2005): Arana, rey del caucho, terror y atrocidades en el Alto Amazonas (Buenos Aires: Emecé)}

Landaburu, Jon (2000-2005): Las lenguas indígenas de Colombia:presentación y estado del arte, Amerindia, n² 29/30, 20042005 
Artigo original

Hegemonia - Revista Eletrônica de Relações Internacionais do Centro Universitário Unieuro

ISSN: $1809-1261$

UNIEURO, Brasília, número Especial, 2016, pp. 121-174.

Lara, Catherine (2010): La complejidad social en las estribaciones andinas orientales durante el período pre-incaico tardío, Antropología, cuadernos de investigación;

Larrea Arias, Julián (2012): De Carlos Crespi a Eriberto Gualinga. Breve historia del cine documental en la amazonia ecuatoriana

La Serna Salcedo, Juan Carlos (2010): Viviendo con el diablo en casa. La enfermedad, hechicería infantil y violencia entre los asháninka desde la perspectiva misionera adventista, Bulletin de l'Institut Français d'Études Andines / 2010, 40 (1): 81-121;

\section{Lausent-Herrera, Isabelle (1996): "Los caucheros y comerciantes chinos en Iquitos a fines del siglo XIX", en Pilar Garcia et al., (eds.), Las raíces de la memoria}

Lehm Ardaya, Zulema (1998): Milenarismo y movimientos sociales en la Amazonía boliviana. La búsqueda de la Loma Santa y la Marcha Indígena por el Territorio y la dignidad (La Paz, Bolivia: APCOB);

Lenaerts, Marc, Spadafora, Ana Maria, ed. (2008): Pueblos indígenas, plantas y mercados: Amazonia y Gran Chaco;

Leonardi, Victor (2001): Fronteiras amazônicas do Brasil: saúde e história social Editora Marco Zero - São Paulo

Leroi-Gourhan, André (1964): Le geste et la parole (Paris, Gallimard, 1964); 
Artigo original

Hegemonia - Revista Eletrônica de Relações Internacionais do Centro Universitário Unieuro

ISSN: $1809-1261$

UNIEURO, Brasília, número Especial, 2016, pp. 121-174.

Lesmes Guerrero, Mildred (2012): La Historia en la historia de El Sueño del Celta de Mario Vargas Llosa: la realidad de la ficción y la ficción en la realidad, Revista Latinoamericana de Ensayos y Opinión (Santiago de Chile);

Levy, Ayda (2012): El Rey de la cocaína. Mi vida con Roberto Suárez Gómez y el nacimiento del primer narcoestado (Random House Mondadori);

Liao, K. 2012. A theory on urban resilience to floods-a basis for alternative planning practices. Ecology and Society 17(4): 48. http://dx.doi.org/10.5751/ES-05231-170448

Liberman, Maria (1983): O levante do Maranhão: "Judeu Cabeça do Motim", Manoel Beckman. São Paulo: Centro de Estudos Judaicos FFLCH/USP, 1983;

Limpias Oritz, Víctor Hugo (2008): El Barroco en la misión jesuítica de Moxos, Varia hist. [online]. 2008, vol.24, n.39, pp. 227-254;

Linhares, JFP (2014): Etnobotânica das principais plantas medicinais comercializadas em feiras e mercados de São Luís, Estado do Maranhão, Brasil.

Lins, Alvaro (1996): Rio Branco (O Barão do Rio Branco): biografía pessoal e história política. São Paulo: Editora Alfa-Omega, 1996 
Artigo original

Hegemonia - Revista Eletrônica de Relações Internacionais do Centro Universitário Unieuro

ISSN: $1809-1261$

UNIEURO, Brasília, número Especial, 2016, pp. 121-174.

Llanos, Héctor y Roberto Pineda (1982): Etnohistoria del Gran Caquetá, siglos XVI- XIX. Bogotá: Fundación de Investigaciones Arqueológicas Nacionales, 1982.

López, José Ignacio (1993): El Estado como núcleo vital. El caso colombiano, Medellín, Colombia: Revista Universidad Eafit, v.29, n.92, 79-90;

López A., Víctor (2006): Amazonía contemporánea y espacio global, Iconos. Revista de Ciencias Sociales (Qutio), n.26, 119-130;

López Garcés, Claudia Leonor (2002): Los Ticuna frente a los procesos de nacionalización en lafrontera entre Brasil, Colombia y Perú. Revista Colombiana de Antropologia, 38,

López Garcés, Claudia Leonor y Pascale de Robert (2001): El legado de Darrell Posey: de las investigaciones etnobiológicas entre los Kayapó a la protección de los conocimientos indígenas;

Lowie, Robert H. (1948): Some Aspects of Political organization among the American Aborigines, The Journal of the Royal Anthropological Institute of Great Britain and Ireland, 78, 1/2;

Lucena Giraldo, Manuel (1990): La Expedición de Límites al Orinoco (1754-1761). En PELAYO, F. (ed.). Pehr Löfling y la expedición al Orinoco, 1754-1761. Madrid: CSIC-Quinto Centenario, 1990, p. 131-145

Lucena Giraldo, Manuel (1991): La expedición imaginaria: la ejecución del Tratado de San Ildefonso en la Guayana española (1776-1784). En 
Artigo original

Hegemonia - Revista Eletrônica de Relações Internacionais do Centro Universitário Unieuro

ISSN: $1809-1261$

UNIEURO, Brasília, número Especial, 2016, pp. 121-174.

Solano, Francisco y Salvador Bernabeu (coords). Estudios (Nuevos y Viejos) sobre la Frontera. Madrid: CSIC, 1991, p. 249-276

Lucena Giraldo, Manuel (1993): Laboratorio tropical. La expedición de límites al Orinoco, 1750-1767. Caracas: Monte Ávila-CSIC, 1993, 337 p.

Lucena Giraldo, Manuel (1997): Ciencia para la frontera. Las expediciones de límites y la ocupación del espacio americano, 1751-1804. En Fronteras y fronterizos en la Historia. Universidad de Valladolid: Instituto de Historia Simancas, 1997, p. 83-114

Ludwig, Emil (1940, 1960): El Mediterráneo. El mar que dio origen a una civilización (Buenos Aires. Fabril Editora);

Lukes, Steven (2005): Power: A Radical View (Palgrave Macmillan);

Luzardo, Alexander (2012): "Genocidio y Ecocidio en el Amazonas", Revista Nueva Sociedad, n. 53 Marzo-Abril, 1981, pp. 51-64;

Mackey, Nathaniel (1993): Discrepant Engagement: Dissonance, CrossCulturality and Experimental Writing Cambridge University Press,

Mann, Charles (2000): «The Good Earth: Did People Improve The Amazon Basin?». Science 287 (788).

Mann, Charles C. (2008): «Ancient earthmovers of the Amazon», Science News Focus, vol. 321, págs. 1148-1152; 
Artigo original

Hegemonia - Revista Eletrônica de Relações Internacionais do Centro Universitário Unieuro

ISSN: $1809-1261$

UNIEURO, Brasília, número Especial, 2016, pp. 121-174.

Marín Silva, Pedro (1994): Etnolingüística e historiografía de la región de los ríos Putumayo, Caquetá y Caguán, Maguare/ Bogota, 9:10, 1994, p. 80-104

Marín Silva, Pedro (2013): Introducción histórica a la etnia Coreguaje: Cultura Tucano occidental de Colombia, Revista Brasileira de Linguística Antropológica,Volume 5, Número 1,

Marín Silva, Pedro (2014): Archivo y semántica: etnohistoria de los guajes del

piedemonte subandino amazónico colombiano, Forma y Función vol. 27, n. ${ }^{2} 2$ julio-diciembre del 2014. Bogotá, Colombia, pp. 115-134;

Martin, Carlos (1868): Memoria del secretario de lo interior y relaciones exteriores de los Estados Unidos de Colombia al congreso federal de 1868 (Bogotá, Diario Oficial);

Martínez, Benjamín (2004): Elementos para el abordaje de la etnopolítica venezolana. Región Guayana, 1992-2002 (Pueblos Karina, Piaroa, Pemón, Yanomami y Yekuana), Revista de Antropología Experimental, n.4, 1-10

Martinez, Paulo Henrique (2012): Petrifying the nation: paleontology collections in Brazil, 1836-1844, Historia, Ciencia, SaudeManguinhos, vol.19 no.4 Rio de Janeiro;

Maury, Mathew F. (1853): The Amazon and the Atlantic Slopes of South America, Washington, F. Taylor, 1853 
Artigo original

Hegemonia - Revista Eletrônica de Relações Internacionais do Centro Universitário Unieuro

ISSN: $1809-1261$

UNIEURO, Brasília, número Especial, 2016, pp. 121-174.

Maxwell, Kenneth (1995); Pombal, Paradox of the Enlightenment (Cambridge, UK: Cambridge University Press);

Mazo, Gabriel del (1962): El Canal Sudamericano (Buenos Aires: Incograf)

McDaniel, Josh (1995): Manejo de Pesca comunal en la Amazonía Peruana: La conexión entre propiedades ecológicas y el sistema de manejo, en Congreso Internacional sobre Manejo de Fauna Silvestre;

McEwan, Colin (2012): Arte precolombino amazónico,

Meabe, Joaquín E. (2016): Autoconservación y antagonismo instituyente entre los Tobas (artículo inédito)

Meade, Robert H. (1994): Suspended sediments of the modern Amazon and Orinoco rivers, In: Iriondo, M. (Ed.), Quaternary of South America, Quaternary International 21, 29-39;

Medina P., María Elena y Gerardo Carrillo Silva (2005): La Cuenca Amazónica y su Importancia Estratégica en el caso de la Amazonía Venezolana (Mexico: Observatorio Geográfico de América Latina);

Meggers, Betty y Clifford Evans (1973): Reconstrucao da Prehistoria Amazonica, Museu Goeldi, Publicacoes Avulsas, 20: 51-69;

Meier, Johannes (2007): "Totus mundus nostra fit habitatio" Jesuitas del territorio de lengua alemana en la América portuguesa y española, en: 
Artigo original

Hegemonia - Revista Eletrônica de Relações Internacionais do Centro Universitário Unieuro

ISSN: $1809-1261$

UNIEURO, Brasília, número Especial, 2016, pp. 121-174.

Zulmira Coelho dos Santos (ed.), São Francisco Xavier. Nos 500 anos do nascimento de São Francisco Xavier: Da Europa para o mundo 15062006. Porto: Centro Interuniversitario de Historia da Espiritualidade, 2007, págs. 57-86;

Meikle, Valerie (1993): A Remo Hacia el Corazón de Nuestro Amazonas (Ediciones Abya-Yala);

Mejía, Kember; Rengifo, Eisa (1995, 2000): Plantas Medicinales de Uso Popular en la Amazonía Peruana (Lima, Agencia Española de Cooperación Internacional);

Mejía, Leonardo (2012): Geopolítica de la Integración Subregional. El rol de Brasil (Ed. La Huella, 2012);

Mejía Valenzuela, Alfonso (1983): La Amazonía Colombiana, Boletín de la Sociedad Geográfica de Colombia. Vol. 36, Número 118

Melo Sampaio, Patrícia y Regina de Carvalho Retal, eds. (2006): Rastros da Memória. Histórias e trajetórias das populações indígenas na Amazônia (Manaos: Universidade Federal do Amazonas);

Melon Ruiz de Gordejuela, Amando (1940): El Viajero Venezolano Francisco Michelena y Rojas, en pos y en contra de Humboldt

Menck, José Theodoro Mascarenhas (2009): A questão do Rio Pirara (1829-1904) (en portugués). Fundação Alexandre de Gusmão. 
Artigo original

Hegemonia - Revista Eletrônica de Relações Internacionais do Centro Universitário Unieuro

ISSN: $1809-1261$

UNIEURO, Brasília, número Especial, 2016, pp. 121-174.

Mendible Zurita, Alejandro (2008): El surgimiento de una nueva historia sudamericana a principios del nuevo milenio: el rol protagónico del Brasil, TF, v.26, n.101;

Mendoza, Marcela (2007): The Aesthetics and Performance of the Ishir of Paraguay, A Contra Corriente. Vol. 5, Numero 1. Feb 2007: 310-413

Mesa Castellanos, Laura Isabel (2011): Etnobotánica de Palmas en la Amazonia Colombiana: Comunidades Indígenas Piapocos del río Guaviare, como estudio de caso

Michelena y Rojas, Francisco (1867): "Exploración Oficial por la primera vez desde el Norte de América del Sur siempre por ríos entrando por las bocas del Orinoco, de los valles de este mismo y del Meta",

Mickle Griesi, Beatriz (2009): Reflexos da acumulação entravada na região amazónica, Universidade de Sao Paulo, Faculdade de Arquitetura):

Mody, Perveez (2011): meeting of the Group for Debates in Anthropological Theory-The anthropological fixation with reciprocity leaves no room for love: 2009 by Soumhya Venkatesan, Jeanette Edwards, Rane Willerslev, Elizabeth Povinelli and Perveez Mody, Critique of Anthropology 2011 31: 210;

Molano-Campuzano, Joaquín (1978): Las Transnacionales en la Amazonia, Nueva Sociedad, n.37, 31-40; 
Artigo original

Hegemonia - Revista Eletrônica de Relações Internacionais do Centro Universitário Unieuro

ISSN: $1809-1261$

UNIEURO, Brasília, número Especial, 2016, pp. 121-174.

Moncayo, Pedro (1862): Colombia y el Brasil, Colombia y el Perú-Cuestión de límites (Valparaiso);

Moniz Bandeira, Luiz Alberto (2014): Los Estados Unidos en la percepción de Brasil, La ONDA digital, No 702

Montalván, Pablo Carmelo (2015): El rescate de Leticia- Novela de una frustración loretana

Moraes, Eduardo Jose de (1890): A Junccao Do Amazonas AoPrata: E Estudo Sobre O Rio Madeira (Nauru Edition)

Morales Chocano, Daniel (2004): Los urarinas de la Amazonía:Un modelo sustentable de subsistencia, InvestigacionesSociales,AñoVIII $N^{\circ} 13, p p$. 43-71 [UNMSM / IIHS, Lima, 2004;

Morales Inga, Sergio (2014): Sobre objetos que vuelan en el cosmos. Crítica al perspectivismo amerindio de Eduardo Viveiros de Castro (Círculo de Estudios Interdisciplinarios)

Moreira Bento, Claudio (2003): Reserva Raposo Serra do Sol potencialmente uma nova questao do Pirará, Universidade Federal Luiz de Fora;

Moreira Neto, Carlos de Araújo (1988): Indios da Amazônia. De maioria a minoria. 1750-1850. Petrópolis, Vozes, 1988 
Artigo original

Hegemonia - Revista Eletrônica de Relações Internacionais do Centro Universitário Unieuro

ISSN : $1809-1261$

UNIEURO, Brasília, número Especial, 2016, pp. 121-174.

Moreira Neto, Carlos de Araújo (1990): Os principais grupos missionarios que atuaram na Amazonia Brasileira entre 1607 e 1759, en Eduardo Hoornaert coord.., Historia da Igreja na Amazonia (Petropolis: Vozes/CEHILA), 63-120;

Moreira Neto, Carlos de Araújo (1993): Henrique João Wilkens e os indios Mura, en Henrique João Wilkens, Muhuraida ou o triunfo da fé (Manaus: Universidade do Amazonas, Rio de Janeiro: Fundacao Biblioteca Nacional), 33-81;

Moreno, Fulgencio (1917): Cuestión de límites con Bolivia: negociaciones diplomáticas, 1915-1917 (Asunción);

Morgan, Muriel L. (2015): Funcionarios borbónicos y espacios de frontera. Objetivos de las políticas de población entre las reducciones de Moxos y Chiquitos, Memoria Americana, no.23-1 Ciudad Autónoma de Buenos Aires jul. 2015

Mouriès, Thomas (2014): ¿Con o sin ancestros? Vigencia de lo ancestral en la Amazonía peruana, Anthropologica vol.32 no.32 Lima jun. 2014;

Mujía, Ricardo (1914): Exposición de los títulos que consagran el derecho territorial de Bolivia, sobre la zona comprendida entre los ríos Pilcomayo y Paraguay (La Paz, Bolivia);

Mujica Rojas, Herbert (2007): Los Peruanoides y la verdad sobre el Trapecio de Leticia, Red Voltaire , 19 de enero de 2007, www.voltairenet.org/article144724.html 
Artigo original

Hegemonia - Revista Eletrônica de Relações Internacionais do Centro Universitário Unieuro

ISSN: $1809-1261$

UNIEURO, Brasília, número Especial, 2016, pp. 121-174.

Müller, Regina Polo (2005): El arte amazónico en la actualidad y su influencia en el arte contemporáneo brasileño, en XXIXO Encontro Anual da ANPOCS.Performance e corpo em movimento no ritual indígena e na cena contemporânea. 2005

Myers, T. P. (2004): Dark Earth in the Upper Amazon. In Amazonian dark earths: Explorations in space and time. B. Glaser, and W.I. Woods, eds. Berlin: Springer, pp. 67-94.

Myers, Thomas P. (1974): Spanish Contacts and Social Change on the Ucayali River, Peru, Ethnohistory, v.21.n.2, 135-157;

Necker, Louis (1990): Indios guaranties y chamanes franciscanos. Las primeras reducciones del Paraguay, 1580-1800 (Asunción: Centro de Estudios Antropológicos, Universidad Católica);

Needham, Joseph (1986): Science and Civilization in China

Neiff, Juan José (1999): El Regimen de Pulsos en Ríos y Grandes Humedales de Sudamérica, en: Adámoli, J. y A. I. Malvárez (eds). Tópicos sobre humedales subtropicales y templados de Sudamérica (UNESCO), 99-150;

Neumann, Eduardo (2008): Escribiendo en la frontera del Paraguay: prácticas de la escritura guaraní durante la demarcación de límites (siglo XVIII), Cultura escrita y sociedad, No. 7, 2008, págs. 159-190; 
Artigo original

Hegemonia - Revista Eletrônica de Relações Internacionais do Centro Universitário Unieuro

ISSN: $1809-1261$

UNIEURO, Brasília, número Especial, 2016, pp. 121-174.

Nogueira, Carlo Eugenio (2012): A Conquista do Brasil Central, Scripta

Nova. Revista Electrónica de Geografía y Ciencias Sociales, v.XVI, n.418 (9);

Nolte, Richard H. (1967): Amazonia: The Domain of Water

Nordenskiöld, Erland (1922, 2003): Indios y blancos: en el nordeste de Bolivia (La Paz: Plural/APCOB);

Nugent, Stephen (2009): Indigenism and Cultural Authenticity in Brazilian Amazonia, Goldsmiths College

Nunes Duarte, Helena (2007): "Civilizing" the Amazon: Amerindians and the Portuguese Crown's Struggle for Sovereignty, 1650-1777, Journal of the Canadian Historical Association, v.18, n.2, 226-253;

Ochoa Abaurre, Juan Carlos (2003): Mito y Chamanismo en la Amazonía (Eunate, Pamplona 2003);

O'Hanlon, Redmond (1993): Entre el Orinoco y el Amazonas. (De nuevo en apuros). Editorial: ANAGRAMA

Olarte-Camacho, Vicente (1932): Las Crueldades de los peruanos en el Putumayo y en el Caquetá. Tercera edición. Front Cover.. Imprenta Nacional, 1932 
Artigo original

Hegemonia - Revista Eletrônica de Relações Internacionais do Centro Universitário Unieuro

ISSN: $1809-1261$

UNIEURO, Brasília, número Especial, 2016, pp. 121-174.

Oliveira, José Aldemir de (2006): Tempo e Espaco Urbano na Amazonia no periodo da borracha, Scripta Nova. Revista Electrónica de Geografía y Ciencias Sociales, v.X, n.218 (35);

Olmedo, Ernesto (2002): Las comunidades de Amazonía ante el mundo occidental: Huitoto, Yagua y Mai Juna, Centro de Investigaciones Precolombinas (CIP);

Oostra, Menno (1991): Misioneros y antropólogos en el Miriti-Parana, Colombia. añossetenta. Revista Colombiana de Antropología, Bogotá, Vol. XXVIII;

Opas, Minna (2012): Ambigüedad epistemológica y moral en el cosmos social de los yine, Anthropologica/año XXXII, N. 32, 2014, pp. 167-189;

Ordenes Lavadenz, Jorge V. (2013): Humberto Vázquez Machicado y la política boliviana con Brasil, La Patria

Ostos Cetina, María del Pilar (2011): Aplicación de modelos geopolíticos en América Latina: Ios casos de Brasil y Colombia, Latinoamérica, n.53, 147-167;

Overing, J. \& M. R. Kaplan (1986): Wotuha, en Los Aborigines de Venezuela. Vol. III, pp 307-412;

Ortiz Gómez, Francisco (2011): Análisis de la traducción y aplicación de la Constitución Colombiana a la lengua Curripaco, Nómadas n.34, Bogotá jan./jun. 2011 
Artigo original

Hegemonia - Revista Eletrônica de Relações Internacionais do Centro Universitário Unieuro

ISSN: $1809-1261$

UNIEURO, Brasília, número Especial, 2016, pp. 121-174.

Osculati, G. (2003 [1854]). Exploraciones de las regiones ecuatoriales a lo largo del Napo y del rio de las Amazonas. Quito: Ediciones Abya Yala

Ospina Bozzi, Ana María (2008): Claves para la comprensión de las relaciones entre la lengua, la cultura y la sociedad yuhup: una perspectiva etnolingüística, Forma y Función, n. ${ }^{0} 21$. Bogotá, Colombia, pp. 189-226

Ospina Hernández, Mariano (2008): La Navegación Fluvial en Colombia, en Seminario Internacional sobre Desarrollo de Puertos Fluviales e Hidrovías (Iquitos, Perú: Antaq);

Ossio, Juan (2014): El Tahuantinsuyo Bíblico. Ezequiel Ataucusi Gamonal y el mesianismo de los Israelitas del Nuevo Pacto Universal.

Editorial: Fondo Editorial de la Biblioteca Nacional del Perú

Pacheco de Oliveira, José (2006): Haciendo etnología con los caboclos de Quirino: la situación etnográfica como una tríada, en Boletín de Antropología Universidad de Antioquia, v.20, n.37, pp 51-80;

Padilla, Ignacio (2010): La Isla de las Tribus Perdidas: la incógnita del mar latinoamericano, Barcelona-. México: Random House Mondadori;

Padilla Pérez, Palmira (1996): Técnica del ensilado biológico de residuos de pescado para ración animal, Folia Amazónica, v.8, n.2, 147-151; 
Artigo original

Hegemonia - Revista Eletrônica de Relações Internacionais do Centro Universitário Unieuro

ISSN : $1809-1261$

UNIEURO, Brasília, número Especial, 2016, pp. 121-174.

Padula, Raphael (2011): Infraestrutura, geopolítica e desenvolvimento na integração sul-americana -uma visão crítica à IRRSA. Artigo do Laboratório de Estudos da América Latina, 2011.

Pagni, Florencia y Fernando Cesaretti (2007): Mato Grosso: el frente olvidado de la Guerra del Paraguay, Todo es Historia edición Abril de 2007

Palmer, John H. (2005): La buena voluntad wichi. Una espiritualidad indígena, Formosa, Salta APCD/CECAZO/EPRAZOL, Grupo de Trabajo Ruta 81, 2005

Pantoja Caldas, Yurgel (2007): Arcanos de Henrique João Wilkens: Muhuraida entre a Bíblia e o Tarô, en D’Angelo, Biagio y Maria Antonieta Pereira, orgs. (2007): Un Río de Palabras. Estudios sobre literatura y cultura de la Amazonia, Lima: Fondo Editorial de la Universidad Católica Sedes Sapientiae, 149-167;

Pardo, Sebastián (2008): Las etnías del chaco en las reivindicaciones territoriales de Bolivia y Paraguay previas a la guerra, Ponencia presentada en el I Taller "Paraguay como objeto de estudio de las ciencias sociales". Junio. Posadas, Argentina

Paredes Bravo, Jorge Rosendo (2002): Proyecto de Dragado para la rehabilitación del terminal fluvial de la ciudad de Iquitos. 
Artigo original

Hegemonia - Revista Eletrônica de Relações Internacionais do Centro Universitário Unieuro

ISSN: $1809-1261$

UNIEURO, Brasília, número Especial, 2016, pp. 121-174.

Paredes Pando, Óscar (2013): Explotación del Caucho-Shiringa. Brasil Bolivia - Perú. Economías extractivo-mercantiles del Alto Acre - Madre de Dios Amazonía Sur-Oriental: Siglos XVI - XX. Tomo II (Cusco: JEditores);

Parker, Eugene Philip, Ed. (1985): The Amazon Caboclo: Historical and Contemporary Perspectives, Studies in Third World Societies, n32, Jun 1985

Pärssinen, Martti ; Denise Schaan y Alceu Ranzi (2009). "Pre-Columbian geometric earthworks in the upper Purús: a complex society in western Amazonia". Antiquity83 (322): 1084-1095.

Pedroza Lima, Flavia y Sílvia Fernanda de Mendonça Figueirôa (2010): Etnoastronomia no Brasil: a contribuição de Charles. Frederick Hartt e José Vieira Couto de Magalhães", Boletim do Museu Paraense Emílio Goeldi: Ciências Humanas, v. 5, n.2;

Peralta Ruiz, Víctor (2006, 2009): La frontera Amazónica en el Perú del siglo XVIII. Una Representación desde la Ilustración, BROCAR, 30, 139158; e Illapa No 4, junio 2009, pp. 7-30;

Perea Borda, Jorge ed. (1998): Los ríos nos unen. Integración Fluvial Suramericana (Santafé de Bogotá: Corporación Andina de Fomento);

Pereira, Edith (2001): Testimony in Stone: Rock art in the Amazon, en Unknown Amazon: culture in nature in ancient Brazil, edited by McEwan, Barreto y Neves (London: British Museum Press), 214-229; 
Artigo original

Hegemonia - Revista Eletrônica de Relações Internacionais do Centro Universitário Unieuro

ISSN: $1809-1261$

UNIEURO, Brasília, número Especial, 2016, pp. 121-174.

Pereira Leal, Felipe Jose (1860): Memoria ofrecida a la consideración de los honorables senadores y diputados al próximo congreso, y a toda la república, sobre el tratado de límites y navegación fluvial ajustado y firmado por plenipotenciarios del Brasil y de Venezuela en 5 de marzo de 1859 (Caracas);

Pereira de Lima, Ricardo Ângelo (2001): La selva amazónica como problema geográfico, Doc. Anàl. Geogr. 38, 2001 99-107

Pérez Salazar, Bernardo (2002): El Minotauro del Laberinto Colombiano, Revista de economía institucional, vol.4 no.6, Bogotá Jan./June 2002

Pérez-Gil, Laura (2001): O sistema médico Yawanáwa e seus especialistas: cura, poder e iniciação xamânica, Cad. Saúde Pública [online]. 2001, vol.17, n.2, pp. 333-344,

Pérez-Gil, Laura y Miguel Carid Naveira (2013): Devenir otro, devenir pariente: las masateadas yaminahua (Amazonía peruana), Revista Española de Antropología Americana

2013, vol. 43, núm. 1, 267-284

Perrier Bruslé, Laetitia (2014) : L'intégration sud-américaine : des enjeux continentaux aux réalités locales. Un exemple à la tri-frontière BoliviePérou-Brésil. Yann Richard; Alia Gana. La régionalisation du monde. Construction territoriale et articulation global/local, Karthala, 2014. <halshs-01077985> 
Artigo original

Hegemonia - Revista Eletrônica de Relações Internacionais do Centro Universitário Unieuro

ISSN: $1809-1261$

UNIEURO, Brasília, número Especial, 2016, pp. 121-174.

Perruchon, Marie (2002): Magia en camino - chamanismo entre los shuar de la Amazonía del Oeste. University: Göteborg University

Pfrimer, Matheus Hoffmann y Antônio Marcos Roseira (2009): Transformações Territoriais na Bolívia: um novo triângulo Estratégico? In: $12^{\circ}$ Encuentro de Geógrafos de América Latina.Montevideo, 2009;

Pineda Camacho, Roberto (1988): El ciclo del caucho, 1850-1932, en Colombia Amazónica (Bogotá, Universidad Nacional de Colombia), pp. 181-209;

Pineda Camacho, Roberto (2000): Holocausto en el Amazonas: una historia social de la Casa Arana. Bogotá: Planeta Colombiana Editorial, 2000.

Pizarro, Ana (2009): Amazonía. El río tiene voces: imaginario y modernización (Chile: FCE);

Polanco Ochoa, Rocío (2013): Leguízamo: hacia una construcción histórica del territorio (Tropenbos Internacional Colombia);

Plotkin, Mark J. (1994): Tales of a Shaman's Apprentice: An Ethnobotanist Searches for New Medicines in the Amazon Rain Forest Penguin Books

Pons Muzzo, Gustavo (1961): Las fronteras del Perú : historia de los límites (Lima : Eds. del Colegio); 
Artigo original

Hegemonia - Revista Eletrônica de Relações Internacionais do Centro Universitário Unieuro

ISSN: $1809-1261$

UNIEURO, Brasília, número Especial, 2016, pp. 121-174.

Ponte Ribeiro, Duarte da (1870): Memoria sobre as questoes de limites entre o imperio do Brazil e a republica da Nova Granada (Rio de Janeiro);

Ponz Sejas, Elizabeth (2005): La medicina tradicional de los tacana y machineri: conocimientos prácticos (La Paz: FUNDACIÓN PIEB);

Porras Barrenechea, Raul (1981): Historia de los límites del Perú, Editorial Universitaria

Porro, A. (1994): Social organization and political power in the Amazon floodplain. In Amazonian Indians from prehistory to the present: Anthropological perspectives. Anna C. Roosevelt, ed. Tucson: University of Arizona Press, pp. 79-94.

Porro, Jesús María (2013): Un Mito geográfico de larga tradición: la perduración cartográfica de la Laguna Parimé, Revista Bibliográfica de Geografía y Ciencias Sociales (Barcelona: Universidad de Barcelona), v.XVIII, n.1032,

Posey, Darrell A. (1992): Kayapó science - alternatives to destruction, en Adelia E. Olivera, y Dense Hamú org., Kayapó science - alternatives to destruction (Belem: Museo Paraense Emilio Goeldi), 19-44;

Post, Charles Johnson (1912): Across the Andes (New York: Outing Publishing Co.);

Prada Alcoreza, Raúl (2003): Territorialidades secretas, Gazeta de Antropología, 19; 
Artigo original

Hegemonia - Revista Eletrônica de Relações Internacionais do Centro Universitário Unieuro

ISSN : $1809-1261$

UNIEURO, Brasília, número Especial, 2016, pp. 121-174.

Prado Robles, Gustavo A. (1996, 2008): Dependencia y subdesarrollo en Macondo: una lectura socio-histórica de Cien Años de Soledad, Revista de Humanidades y Ciencias Sociales, v.2, n.2, 83-110; y en Gustavo A. Prado Robles, Ensayos de historia económica, Instituto de Investigaciones Económicas y Sociales "José Ortiz Mercado", Universidad Autónoma Gabriel René Moreno, 2008, 145-170;

Pressler, Gunter Karl (2012): Gurupá - das ruínas aos cemitérios, Estudos Avanzados, vol.26 no.76 São Paulo Sept./Dec. 2012

Prudencio Lizón, Ramiro (2011). Historia de la negociación de Charaña. La Paz: Plural Editores

Puglisi, Giuseppe (1933): Dal Plata al Orinoco per viafluviale, publicado en la revista "Le Vie d'Italia e del Mondo" (año I, Nos. 11 y 12), noviembre y diciembre de 1933

Querejazu Lewis, Roy (1991): Arte rupestre del departamento de Santa Cruz. Sociedad de Investigación del ArteRupestre de Bolivia (SIARB). La Paz.

Quesada, Vicente G. (1881): "La alianza contra Rosas y Oribe. El Brasil, Montevideo y las Provincias de Entre Ríos y Corrientes". Nueva Revista de Buenos Aires, tomo III. Buenos Aires, 1881. 
Artigo original

Hegemonia - Revista Eletrônica de Relações Internacionais do Centro Universitário Unieuro

ISSN: $1809-1261$

UNIEURO, Brasília, número Especial, 2016, pp. 121-174.

Quesada, Vicente G. (1882): "Diplomacia americana. El Brasil y el Río de la Plata. Negociaciones internacionales. 1808-1812". Nueva Revista de Buenos Aires, n. ${ }^{\circ} 6$.

Buenos Aires, 1882

Quesada, Vicente G. (1920): La Política Imperialista del Brasil y las cuestiones de límites de las repúblicas sudamericanas (Buenos Aires : La Cultura Argentina);

Quijano, Aníbal (2006): El "movimiento indígena" y las cuestiones pendientes en América Latina, Argumentos, v.19, n.50, 51-77;

Quijano Otero, José María (1869): Memoria histórica sobre límites entre la República de Colombia y el Imperio del Brasil. Editorial: Bogotá: Imprenta de Gaitán;

Quintero Ramírez, Oscar Alejandro (2014): "El racismo cotidiano en la universidad colombiana desde la experiencia vivida por los estudiantes negros en Bogotá" . En: Universitas Humanistica ed: Editorial Pontificia Universidad Javeriana, v.77, fasc.N/A, p.71-94;

Ramirez, Luis Hernán (1997): Samuel Fritz (1654-1725) defensor de la peruanidad en el territorio amazónico. Revista Alma Mater N¹3-14, agosto de 1997;

Ramírez Bonilla, Juan José (2005): América Latina ante Asia-Pacífico: respuestas nuevas a problemas nuevos, Anuario Asia-Pacífico, No. 1; 
Artigo original

Hegemonia - Revista Eletrônica de Relações Internacionais do Centro Universitário Unieuro

ISSN: $1809-1261$

UNIEURO, Brasília, número Especial, 2016, pp. 121-174.

Ramírez Ponce, Abdie (2008): Informe antropológico. Etnías amazónicas en Vilcabamba (siglo XVI al XX), Institut français d'études andines, Fondo Editorial Universidad Nacional Mayor de San Marcos,p. 179-209

Ramos Pérez, Demetrio (1946): El Tratado de Límites de 1750 y la expedición de Iturriaga al Orinoco. Madrid: CSIC, 1946;

Ramos Pérez, Demetrio (1988): Las ideas geográficas del padre Gumilla. La comunicación Orinoco-Amazonas y su negación. En Estudios de Historia Venezolana (Academia Nacional de la Historia), p. 571-596;

Rausch, Jane M. (2013): The Controversial Career of Sophie Muller (19101995): An Assessment of her Influence as a Protestant Evangeliston Colombia's Far Eastern Frontier

Reeve, M. E. (1993): Regional Interaction in the Western Amazon: The Early Colonial Encounter and the Jesuit Years: 1538-1767. Ethnohistory 41(1):106-138

Renard-Casevitz, F-M. (2002): Social Forms and Regressive History: From the Campa Cluster to the Mojos and from the Mojos to the Landscape Terrace-Builders of the Bolivian Savanna. In Comparative Arawakan histories: Rethinking language family and culture area in Amazonia. J.D. Hill, and F. Santos-Granero, eds. Urbana: University of Illinois Press, pp. 123-146.

Renshaw, John (2002): The Indians of the Paraguayan Chaco: Identity and Economy.Lincoln and London: University of Nebraska Press, 2002. 
Artigo original

Hegemonia - Revista Eletrônica de Relações Internacionais do Centro Universitário Unieuro

ISSN: $1809-1261$

UNIEURO, Brasília, número Especial, 2016, pp. 121-174.

Reverte, Javier (1944): El río de la desolación (Madrid: Areté);

Reyes-García, V. y N. Martí Sanz (2007): Etnoecología: punto de encuentro entre naturaleza y cultura, en: Ecosistemas. Revista científica y técnica de ecología y medio ambiente, 16 (3): 46-55. Septiembre 2007

Reynoso, Carlos (2014): Crítica de la Antropología Perspectivista (Viveiros de Castro-Philippe Descola-Bruno Latour)

Ribeiro, Nelson de Figueiredo (2006): A questão geopolítica da Amazônia: da soberania difusa a soberania restrita. Belém: EDUFPA, 2006

Ribeiro, Darcy; Carlos de Araújo Moreira Neto, y Gisele Jacon de A. Moreira (1992): La Fundación de Brasil: testimonios, 1500-1700, Fundacion Biblioteca Ayacucho

Rice, Stephen P.; André G. Roy; y Bruce L. Rhoads, ed. (2008): River Confluences, Tributaries and the Fluvial Network, John Wiley and sons, Engl;

Richard, Nicolas (2008): Los baqueanos de Belaieff. La mediación indígena en la entrada militar al Alto Paraguay, en Nicolas Richard. Mala guerra. Los indígenas en la Guerra del Chaco, Asunción del Paraguay : Servilibro / Museo del Barro, pp. 291-333, 2008

Richardson, Lucas (2015): "For the Good of the King's Vassals" Francisco Xavier de Mendonça Furtado and the Portuguese Amazon, 1751-1759, Ph.D. Thesis University of Kentucky; 
Artigo original

Hegemonia - Revista Eletrônica de Relações Internacionais do Centro Universitário Unieuro

ISSN: $1809-1261$

UNIEURO, Brasília, número Especial, 2016, pp. 121-174.

Ricupero, Rubens (2011): Joaquim Nabuco e as fronteiras do Brasil, conferencia proferida na Academia Brasileira de Latras como parte do ciclo em memoria dos cem anos da norte de Joaquim Nabuco, Politica Externa, v.19, n.4, 175-184;

Riester, Jürgen \& Bernd Fischermann (1976): En busca de la Loma Santa. La Paz-Cochabamba, Editorial Los Amigos del Libro

Rival, Laura (1998): Domestication as a Historical and Symbolic Process: Wild Gardens and Cultivated Forest in the Ecuadorian Amazon, in Advances in Historical Ecology, ed. by William Balée (New York: Columbia University Press), 232-250;

Rival, Laura (2012): The materiality of life: Revisiting the anthropology of nature in Amazonia, Indiana, n.29, 127-143;

Roberts, Ralph Leon (1975): Migration and colonization in Colombian Amazonia : agrarian reform or neo-latifundismo? Ph. D. Syracuse University 1975

Rodrigues Ferreira, Manoel (1960): "A Ferrovia do Diabo- Historia de uma Estrada de Ferro na Amazonia".

Rodríguez Mir, Javier (2012): Los sinuosos caminos del racismo. Violencia y racismo ambiental en Argentina (Editorial Académica Española); 
Artigo original

Hegemonia - Revista Eletrônica de Relações Internacionais do Centro Universitário Unieuro

ISSN: $1809-1261$

UNIEURO, Brasília, número Especial, 2016, pp. 121-174.

Rodríguez, Carlos A. y María Clara van der Hammen (2012): Manejo indígena de la fauna en el medio y bajo río Caquetá (Amazonia Colombiana). Tradición, transformaciones y desafíos para su uso sostenible, Pp: 325-338, En: Polanco-Ochoa, R. (Ed.). Manejo de fauna silvestre en Amazonia y Latinoamérica. Selección de trabajos V Congreso Internacional. CITES, Fundación Natura. Bogotá.

Rodríguez Achung, Fernando (1995): El recurso del suelo en la Amazonía Peruana, diagnóstico para su investigación, Documento Técnico (Iquitos), n.14

Rodríguez Pardo, Javier (2009): Vienen por el oro, vienen por todo. Buenos Aires : Fundación Centro de Integración, Comunicación, Cultura y Sociedad (1a edición). Argentina: Ediciones CICCUS

Rodríguez R., Karla Juliana; y Maldonado, Jorge Higinio (2009): Importancia de los productos forestales maderables y no maderables en los hogares de Puerto Nariño (Amazonas, Colombia), Cuadernos de Desarrollo Rural, vol. 6, núm. 62, enero-junio, 2009, pp. 31-52

Rojas Grández, Franco y José Alvarez Alonso (2007): Plan de Manejo Adaptativo de Bosques Inundables ("Tahuampas") formulado de manera participativa con las comunidades de la RNAM, Instituto de Investigaciones de la Amazonía Peruana - IIAP

Rojas Zolezzi, Enrique (2014): El morral del colibrí. Mitología, chamanismo y ecología simbólica entre los Ashaninka del Oriente peruano (Lima); 
Artigo original

Hegemonia - Revista Eletrônica de Relações Internacionais do Centro Universitário Unieuro

ISSN: $1809-1261$

UNIEURO, Brasília, número Especial, 2016, pp. 121-174.

Roller, Heather Flynn (2013): Expedicoes coloniaias de coleta e a busca por oportunidades no sertao amazónico, c. 1750-1800, Revista de Hisatoria (Sao Paulo), n.168, 201-243;

Romero Gallardo, Michelle Vyoleta; Rodrigo Peña González; y Pablo Armando González Ulloa Aguirre (2012): Brasil: raíces geopolíticas y actual influencia en expansión, Polít. cult. no.37 México ene. 2012

Roosevelt, Theodore (1914): Through the Brazilian Wilderness (New York: Charles Scribner)

Rosas Moscoso, Fernando (2008): Del Río de la Plata al Amazonas. El Perú y el Brasil en la Época de la Dominación Ibérica" (Lima: Universidad Ricardo Palma)

Rosas Riaño, Diana (2007): El dinero aguas arriba en el Mirití-Paraná: Cuestión de líderes, en: Amazonia desde dentro. Aportes a la investigación de la Amazonia colombiana" Amazonia desde adentro: Aportes a la investigación de la Amazonia Colombiana ed: Editora Guadalupe Ltda, v. , p.51-77, 2007;

Rose, Françoise (2012): Mojeño trinitario, en: Mily Crevels y Pieter Muysken (eds.) Lenguas de Bolivia, tomo III Oriente. La Paz: Plural editores;

Roselló Osinaga, Jordi (2004): Falacia Histórica de "La Nación Camba, "Tribuna boliviana", (05/06/2004 
Artigo original

Hegemonia - Revista Eletrônica de Relações Internacionais do Centro Universitário Unieuro

ISSN : $1809-1261$

UNIEURO, Brasília, número Especial, 2016, pp. 121-174.

Rosenzweig, Franz (2015): Escritos sobre la Guerra (Salamanca, España:

Ed. Sígueme);

Roth, Walter E. (ed. and trans.) (1922-23): Richard Schomburgk's Travels in British Guiana 1840-1844, 2 vols (Georgetown: Daily Chronicle Office, 1922, 1923).

Rumrrill, Róger (2013): Extirpación de idolatrías, extractivismo desenfrenado,

chamanismo amazónico y la utopía social indígena del siglo XXI, en Varese, Stefano; Frédérique Apffel-Marglin; y Róger Rumrrill (coordinadores), Selva Vida. De La Destrucción de la Amazonía al Paradigma de la Regeneración (Editorial: IWGIA), 103-116;

Sala, María (1984): Geomorfologia actual: guia conceptual,temática y bibliográfica, En: Revista de geografía. -- Vol. 18 (ene-dic. 1984);

Sala Catalá, José (1994): La ciencia en las expediciones de límites hispano-portuguesas: su proyección internacional, Acta Hispanica ad Medicinae Scientiarumque Historiam Illustrandam. Vol. 12, 1992, pp. 23$3 \backslash 3$;

Salamanca, Carlos (2009): Revisitando Napalpí: Por una antropología dialógica de la acción social y la violencia, RUNA XXXI, (1), pp 67-87, 2009, FFyL - UBA 
Artigo original

Hegemonia - Revista Eletrônica de Relações Internacionais do Centro Universitário Unieuro

ISSN: $1809-1261$

UNIEURO, Brasília, número Especial, 2016, pp. 121-174.

Salamanca T., Demetrio (1916): La Amazonia colombiana: estudio geográfico, histórico y jurídico en defensa del territorial de Colombia, Volume 2. (Bogotá: Imprenta nacional);

Salazar Cardona, Carlos Ariel; Franz Gutiérrez Rey; y Martín Franco Angulo (2006): Vaupés: entre la Colonización y las Fronteras (Instituto Amazónico de Investigación Científica SINCHI);

Sampaio Goes Filho, Synesio (1991): Navegantes, bandeirantes, diplomatas. Aspectos da descoberta do continente, da penetraçao do território brasileiro extra-Tordesilhas e do estabelecimento das fronteiras da Amazonia. Brasilia : Fundaçao Alexandre de Gusmão, Instituto de pesquisa de relações internacionais, IPRI, 1991. http://sistemas.mre.gov.br/kitweb/datafiles/IRBr/ptbr/file/CAD/LXIII\%20CAD/ Direito/navegantes,\%20bandeirantes,\%20diplomatas.pdf

Sánchez-Gijon, Antonio (1990): La integración en la Cuenca del Plata. Madrid: Instituto de Cooperación Iberoamericana; Ediciones de Cultura Hispánica, 1990;

Sánchez Montañés, Emma (): El arte cerámico de la Amazonia

Sánchez Vásquez, Melisa (2010): Cambio social entre los machiguengas. El caso de las comunidades de Koribeni y Matoriato

Sanjad, Nelson (2004): Charles Frederick Hartt and the institutionalization of the natural sciences in Brazil. Hist. cienc. saudeManguinhos, vol.11 no.2 
Artigo original

Hegemonia - Revista Eletrônica de Relações Internacionais do Centro Universitário Unieuro

ISSN : $1809-1261$

UNIEURO, Brasília, número Especial, 2016, pp. 121-174.

Santos Granero, Fernando (1986): "Power, Ideology and the Ritual of Production in Lowland South America," Man, New Series, 21: 4, 657-679,

Santos Granero, Fernando (1996): Globalización y cambio en la Amazonía indígena (Editorial Abya Yala, Ene 1, 1996);

Santos Granero, Fernando (2004): Escribiendo la historia en el paisaje: espacio, mitología y ritual entre la gente yanesha, en Alexandre Surrallés, y Pedro García Hierro, ed., Tierra Adentro. Territorio indígena y percepción del entorno, IWGIA, 187-220

Santos Granero, Fernando ed. (2009): The ocult life of things: Native Amazonian Theories of Materiality and Personhood, Tucson: University of Arizona Press

Sathler, Douglas; Roberto L. Monte-Mór; José Alberto Magno de Carvalho; y Alfredo Costa (2010): Urban hierarchy in the brazilian Amazon, Rev. bras. estud. popul. vol.27 no.2 São Paulo July/Dec. 2010

Sayago, Doris, Jean-François Tourrand, Marcel Bursztyn, y José Augusto Drummond, coord. (2010): L'Amazonie, un demi-siècle après la colonisation, ed. Quae

Scarfi, Juan Pablo (2013): La emergencia de un imaginario latinoamericanista y antiestadounidense del orden hemisférico: de la Unión Panamericana a la Unión Latinoamericana (1880-1913), Revista Complutense de Historia de América, vol. 39, 81-104 
Artigo original

Hegemonia - Revista Eletrônica de Relações Internacionais do Centro Universitário Unieuro

ISSN: $1809-1261$

UNIEURO, Brasília, número Especial, 2016, pp. 121-174.

Schneider, David (1984): A Critique of the Study of Kinship (University of Michigan Press);

Seeger, Anthony (1980): Os índios e nós: estudos sobre sociedades tribais brasileiras (Campus, 1980);

Seeger, Anthony (1981): Nature and Society in Central Brazil: The Suyá Indians of Mato Grosso (Harvard University Press, 1981);

Seeger, Anthony (1987): Why Suyá Sing: A Musical Anthropology of an Amazonian People, Cambridge University Press, 1987

Selverston-Scher, Melina (2001): Ethnopolitics in Ecuador: Indigenous Rights and the Strengthening of Democracy (North-South Center Press)

Serje, Margarita (2005): El revés de la nación. Territorios salvajes, fronteras y tierra de nadie. Bogotá: Universidad de Los Andes.2005

Serje, Margarita (2013): El mito de la ausencia del estado: la incorporación económica de las "zonas de frontera" en Colombia, Cahier des Amérique Latines, 7, 95-117;

Severo, Luciano Wexell (2012): A importância geopolítica da Bolívia e a integração da América do Sul, Carta Maior, junho 2012, Seminário de PósGraduação: Associação Brasileira de RelaçõesInternacionais, Brasília, Julhode2012

http://cartamaior.com.br/?/Editoria/Internacional/A-importanciageopolitica-da-Bolivia-e-a-integracao-da-America-do-Sul/6/25649 
Artigo original

Hegemonia - Revista Eletrônica de Relações Internacionais do Centro Universitário Unieuro

ISSN: $1809-1261$

UNIEURO, Brasília, número Especial, 2016, pp. 121-174.

Sevilla Pérez, Ana (2013): La incompleta nacionalización de la amazonía ecuatoriana en el siglo XIX vista desde el mapa de Theodor Wolf (1892), Apuntes [online]. 2013, vol.26, n.1, 102-113;

Shanley, Patricia; Margaret Cymerys, Murilo Serra, y Gabriel Medina, editores

(2001): Fruit trees and useful plants in Amazonian life (FAO)

Shkrada Resk, Sucena (2010): Xingu- Um paraíso sobameaca http://leiturasdahistoria.uol.com.br/ESLH/Edicoes/19/artigo134622-

1.asp

Siemann, Yvonne (2012). "Descendientes de japoneses en Santa Cruz.en: Villar, Diego e Isabelle Combès: "Las tierras bajas de Bolivia: miradas históricas y antropológicas." Santa Cruz de la Sierra: El País.

Silva Fajardo, Germán (2009): Champanes, vapores y remolcadores. Historia de la navegación y la ingeniería fluvial Colombiana, en Academia Colombiana de la Ingeniería y las Obras Públicas, Cuaderno de Historia, n.1;

Silva Ugarte, Auxiliomar (2006): El avance misional hacia la parte alta de la Amazonia, en Patrícia Melo Sampaio y Regina de Carvalho Retal, eds. Rastros da Memória. Histórias e trajetórias das populações indígenas na Amazônia (Manaos: Universidade Federal do Amazonas, 2006).

Smith, Nigel J.H. (1980): «Anthrosols and human carrying capacity in Amazonia». Annals of the Association of American Geographers 
Artigo original

Hegemonia - Revista Eletrônica de Relações Internacionais do Centro Universitário Unieuro

ISSN: $1809-1261$

UNIEURO, Brasília, número Especial, 2016, pp. 121-174.

Smith, Richard Chase (1977): Deliverance from chaos for a song: a social and religious interpretation of the ritual performance of Amuesha music, thesis, Cornell University

Smith, Richard Chase (2012):"¿Un sustrato Arawak en los Andes centrales? La historia oral y el espacio histórico cultural Yánesha", en: Jean Pierre Chaumeil, Oscar Espinosa, Manuel Cornejo, Eds. Por donde sopla el viento. Lima: Pontifica Universidad Católica del Peru and Instituto Francés de Estudios Andinos

Śniadecka-Kotarska , Magdalena (2010): La Etnopolítica en Bolivia, Revista del CESLA, vol. 1, núm. 13, 2010, pp. 331-344

Soledad Suescún, Javier Iván y Carmen Egea Jiménez (2008): Migraciones y conflictos. El desplazamiento interno en Colombia, Convergencia. Revista de Ciencias Sociales, vol. 15, núm. 47, mayoagosto, 2008, pp. 207-235

Soto Holguín, Álvaro (1972): Mitos de los Cubeos. Bogotá: Universidad de Los Andes

Sousa Santos, Boaventura de, y José Luis Exeni Rodríguez ed. (2012): Justicia indígena, plurinacionalidad e interculturalidad en Bolivia (Ediciones Abya Yala Fundación Rosa Luxemburg);

Stanfield, Michael (2009): Caucho, conflicto y cultura en la Amazonía Noroeste: Colombia, Ecuador y Perú en el Putumayo, Caquetá, Napo, 1850-1933. Quito: Ediciones Abya Yala, 2009. 
Artigo original

Hegemonia - Revista Eletrônica de Relações Internacionais do Centro Universitário Unieuro

ISSN: $1809-1261$

UNIEURO, Brasília, número Especial, 2016, pp. 121-174.

Stang, Carla (2011): A Walk To The River In Amazonia: Ordinary Reality for the Mehinaku Indians, online article

Steiman, Rebeca (2002): A geografía das ciudades de frontera: un estado de caso de Tabatinga (Brasil) e Leticia (Colombia).

Stenzel, Kristine (2005): Multilingualism in the Northwest Amazon, Revisited, In: Memórias del Congreso de Idiomas Indígenas de Latinoamérica. Austin: University of Texas;

Suess, Pablo; Juan F. Gorski, M. M., y Beat Dietschy (1998): Desarrollo Histórico de la Teología India

Zhigao Sun a,b,c, Wenguang Sund, Chuan Tong a,b,c, Congsheng Zeng $a, b, c, \quad$ (2015): China's coastal wetlands: Conservation history, implementation efforts, existing issues and strategies for future improvement

Surrallés, Alexandres (2013): Destino, muerte y regeneración entre los Candoshi, en Varese, Stefano; Frédérique Apffel-Marglin; y Róger Rumrrill (coordinadores), Selva Vida. De la Destrucción de la Amazonía al Paradigma de la Regeneración (Editorial: IWGIA), 117-134;

Susnik, Branislava (1968): Chiriguanos I. Dimensiones etnosociales (Asunción Museo Etnográfico "Andrés Barbero"); 
Artigo original

Hegemonia - Revista Eletrônica de Relações Internacionais do Centro Universitário Unieuro

ISSN: $1809-1261$

UNIEURO, Brasília, número Especial, 2016, pp. 121-174.

Susnik, Branislava (1975): Dispersión tupí-guaraní prehistórica. Ensayo analítico (Asunción Museo Etnográfico "Andrés Barbero");

Suzuki, Taku (2010). "Embodying Belonging: Racializing Okinawan Diaspora in Bolivia and Japan", University of Hawai'i Press

Than, Ker (2006): Amazon River Flowed Backwards in Ancient Times

Tocantins, Leandro (1952, 1983): O rio comanda a vida: uma interpretação da Amazônia. Livraria J. Olympio, 1983

Tombini Wittman, Luisa (2011): La música en las aldeas de la amazonía portuguesa (siglo XVII), Vibrant, Virtual Brazilian Anthropology, v.8, n.1,

Toro Montalvo, César (2007): Mitología amazónica. Estudio de aproximación desde la diversidad de mitos, leyendas, cuentos maravillosos, mitólogos y compiladores orales de la Amazonia, en D’Angelo, Biagio y Maria Antonieta Pereira, orgs. (2007): Un Río de Palabras. Estudios sobre literatura y cultura de la Amazonia, Lima: Fondo Editorial de la Universidad Católica Sedes Sapientiae, 49-88;

Tournon, Jacques (2002): La merma mágica. Vida e historia de los Shipibo-Conibo del Ucayali, Lima, CAAAP, 2002

Townsley, Graham (1993): 'Song Paths: The Way and Means of Yaminahua Shamanic Knowledge'. L'Homme. Vol. 33 pp.449-468 
Artigo original

Hegemonia - Revista Eletrônica de Relações Internacionais do Centro Universitário Unieuro

ISSN: $1809-1261$

UNIEURO, Brasília, número Especial, 2016, pp. 121-174.

Troccaz, Antoine (2012): L'émergence d'un mouvement indigène organisé en Colombie: vers la redéfinition de la notion originelle de nation, Pandora $N^{\circ} 11-2012$,

Truffin, Barbara (2009): El papel de los derechos indígenas en la amazonia ecuatoriana Nueva antropología, vol.22, no.71, México jul./dic. 2009;

Trujillo-C., William y Victor H. Gonzalez (2011): Plantas medicinales utilizadas por tres comunidades indígenas en el noroccidente de la Amazonia colombiana, mundo amazónico 2, 2011,283-305;

Turtera Pereira, David Lugli (2009): Expansao dos Tupi-Guarani pelo Territorio Brasileiro: Correlacao entre a Familia Lingüística e a Tradicao Ceramica, Topos, v.30, n.1, 29-80;

Tyuleneva, Vera (2003): La leyenda del Paititi: versiones modernas y coloniales. Revista Andina, 36: 193-211.

Ulloa, Antonio de y Juan, Jorge (1746): Disertación histórica y geográfica sobre el meridiano de demarcación entre los dominios de España y Portugal, y los parages por donde pasa en la América meridional, conforme a los tratados y derechos de cada estado, y las más seguras y modernas observaciones. Madrid : Imprenta Real, A. Marin, 1746. Accesible en la Congress Library, acceso vía web: http://trapalanda.bn.gov.ar/jspui/handle/123456789/4069 p.e. 
Artigo original

Hegemonia - Revista Eletrônica de Relações Internacionais do Centro Universitário Unieuro

ISSN: $1809-1261$

UNIEURO, Brasília, número Especial, 2016, pp. 121-174.

Urban, Greg (1992): A Historia da Cultura Brasileira Segundo as Linguas

Nativas, en M. C. Cunha (Org.), Historia dos Indios no Brasil, Sao Paulo:

FAPESP/SMC, 87-102;

Uribe, Antonio José (1931): Colombia y el Perú: las cuestiones de límites y de libre navegación fluvial (Bogotá : Minerva);

Uribe Mosquera, Tomás (2013): Caucho, explotación y guerra: configuración de las fronteras nacionales y expoliación indígena en Amazonia, Mem.soc (Bogotá), 17 (34), 34-48;

Urzainki Mikeleiz, Asunción (2006): América Latina ante el paradigma y los desafíos de la globalización, Lurralde, n.29;

Uzendoski, Michael A. (2006): The Return of Jumandy: Historicity, Kinship, and Language in Napo, Iconos. Revista de Ciencias Sociales, n.26, 161-172;

Vacas Mora, Víctor (2008): Cuerpos, cadáveres y comida: canibalismo, comensalidad y organización social en la Amazonía, Antípoda, n.6, 271291;

Valdivia, Gabriela (2007): The "Amazonian Trial of the Century": Indigenous Identities, Transnational Networks, and Petroleum in Ecuador, Alternatives: Global, Local, Political, 32:1, 41-72; 
Artigo original

Hegemonia - Revista Eletrônica de Relações Internacionais do Centro Universitário Unieuro

ISSN: $1809-1261$

UNIEURO, Brasília, número Especial, 2016, pp. 121-174.

Valencia, Lenin coord. (2015): Las Rutas del Oro Ilegal. Estudios de Caso en Cinco Países Amazónicos (Lima: Sociedad Peruana de Derecho Ambiental);

Valenzuela, Pilar M. (2000): Cuando los Otros no son los Mismos Ideologia y Análisis Gramatical: un caso desde la Amazonía Peruana, Lexis XXIV 1 (2000): 49-81.

Vallvé Vallori, Frederic (2012): La Barraca Gomera Boliviana: etnicidad, mano de obra y aculturación (1880-1920), Boletín Americanista, año LXII, 2, n. 65, Barcelona, 2012, págs. 61-83;

Van Bredam, Orlando (2009): Rincon Bomba. Lectura de una matanza, Van Kessel, Juan (1993) La senda de los kallawayas. CIDAS, Chile

Vanzolini Figueiredo, Marina (2008): Imagens do Poder: a política xinguana na etnografía, cadernos de campo, São Paulo, n. 17, p. 89-109, 2008

Vasco-Palacios, Aída Marcela; Sandy Carolina Suaza; Mauricio CastanõBetancur; y Ana Esperanza Franco-Molano (2008): Conocimiento etnoecólogico de los hongos entre los indígenas Uitoto, Muinane y Andoke de la Amazonía Colombiana, Acta Amaz. vol.38 no.1 Manaus 2008; http://dx.doi.org/10.1590/S0044-59672008000100004

Vázquez Machicado, Humberto (1990): Para una historia de los límites entre Bolivia y el Brasil. Librería Editorial "Juventud", 1990 
Artigo original

Hegemonia - Revista Eletrônica de Relações Internacionais do Centro Universitário Unieuro

ISSN: $1809-1261$

UNIEURO, Brasília, número Especial, 2016, pp. 121-174.

Vega Orcacitas, Mario (2001): Etnobotánica de la Amazonía Peruana (Ediciones Abya-Yala).

Velilla Laconich, Julia (1994), El Reencuentro Paraguayo-Boliviano, 1994

Vianna, Hélio (1949): História das fronteiras do Brasil. Rio de Janeiro : Ministério da Guerra, 1949.

Vidal, Lux (1992): "A pintura corporal e a arte gráfica entre os KayapóXikrin do Cateté. en: Grafismo indígena, estudos de antropologia estética, São Paulo: Studio Nobel/FAPESP/ Edusp, 1992

Vidal, Mario (2008): Napalpí. La herida abierta (Resistencia: Librería de la Paz);

Villafañe Santos, Luis Claudio (2007): El Imperio del Brasil y las Republicas del Pacifico (Quito, Ecuador: Corporación Editora Nacional);

Villanueva Urquijo, Pedro (2006): "Los Peruanoides", Editorial: DESA SA

Villar, Diego (2015): Cuatro destinos del guerrero: teorías de la guerra indígena en las tierras bajas sudamericanas, Corpus, v.5, n.1

Villar, Diego; e Isabelle Combés (2013): La Tierra sin Mal. Leyenda de la creación y destrucción de un mito, Tellus, año 13, n.24, 202-225; 
Artigo original

Hegemonia - Revista Eletrônica de Relações Internacionais do Centro Universitário Unieuro

ISSN: $1809-1261$

UNIEURO, Brasília, número Especial, 2016, pp. 121-174.

Villar, Diego; Lorena Córdova, e Isabelle Combés (2013): "La reducción imposible: Las expediciones del padre Negrete a los Pacaguaras (17951800)", (Editorial UCB, colección "Scripta Atochtona");

Vincent, W.M. (1986): "Máscaras. Objetos rituais do Alto Rio Negro", en: suma etnológica brasileira, Ribeiro,B.G.(coord.), Petrópolis: Finep/Vozes, 1986;

Vinicius de Freitas, Marcus (2001): Hartt: expedições pelo Brasil imperial (1865-1878), São Paulo, Metalivros, 2001

Viola Recasens, Andreu (1993): La Cara Oculta de los Andes. Notas para una redefinición de la relación histórica entre sierra y selva, en: Boletín Americanista, 1993, n 42-43, 7-22;

Virtanen, Pirjo Kristiina (2008): Los procesos de modernización en la Amazonia brasileña: Lógicas sociales de los pueblos indígenas y la interacción entre campos socials, Sociológica (Méx.) vol.23 no.67 México may./ago. 2008;

Viveiros de Castro, Eduardo (2010): Metafísicas caníbales. Líneas de antropología postestructural (Madrid: Katz editores);

Viveiros de Castro, Eduardo (2012): Cosmological perspectivism in Amazonia and elsewhere (Manchester: HAU Network of Ethnographie);

Viveros Vigoya, Mara y Sergio Lesmes Espinel (2014): Cuestiones raciales y construcción de Nación en tiempos de multiculturalismo, Universitas Humanística, n.77; 
Artigo original

Hegemonia - Revista Eletrônica de Relações Internacionais do Centro Universitário Unieuro

ISSN: $1809-1261$

UNIEURO, Brasília, número Especial, 2016, pp. 121-174.

Walker, Harry (2009): Transformations of Urarina kinship, Journal of the Anthropological Society of Oxford JASO online, V.I, n.1

Walker, Harry (2013) State of play: the political ontology of sport in Amazonian Peru. American ethnologist, 40 (2). pp. 1-49

Walker, Harry (2014): Under a watchful eye: self, power, and intimacy in Amazonia London, Berkeley: Univ. of California Press;

Walker, Harry (2015): Justice and the dark arts: law and shamanism in Amazonia. American Anthropologist, 117 (1), pp. 47-58

Walker, Robert et al., (2011): The Amazonian Theater of Cruelty, Annals of the Association of American Geographers, Volume 101, Issue 5, 2011

Wasserman, Renata (2009): Exotic science and domestic exoticism: Theodore Roosevelt and J. A. LeiteMoraes in Amazonia, Ilha do Desterro, Journal of EnglishLanguage, Literatures in English andCultural Studies, n.57, pp.59-78UFSC

White, Jason Q. (2007): Tributary/mainstem interactions, the River Continuum Concept and the Grande Ronde River

Wright, Robin M. (1998): Cosmos, Self, and History in Baniwa Religion: For Those Unborn 
Artigo original

Hegemonia - Revista Eletrônica de Relações Internacionais do Centro Universitário Unieuro

ISSN: $1809-1261$

UNIEURO, Brasília, número Especial, 2016, pp. 121-174.

Wright, Robin M (2006): In Darkness and Secrecy: The Anthropology of Assault Sorcery and Witchcraft in Amazonia, Journal of Latin American Anthropology, November, 2006

Yataco, Myriam (2012): Politiques publiques et exclusion des langues indigènes au Pérou

Droit et Cultures[En ligne], 63, 110-142;

Zahluth Bastos, Rodolpho (2009): La biopiraterie : réalité ou manipulation médiatico-politique ? Le cas des Indiens Krahó en Amazonie brésilienne, Hérodote $3 / 2009$ (No 134) , p. 138-150

Zárate Botía, Carlos Gilberto (2001): "La formación de una frontera sin límites: los antecedentes coloniales del Trapecio Amazónico colombiano", en: C. Franky y C. Zárate (Eds). Imani Mundo. Estudios en la Amazonia colombiana.

Zárate Botía, Carlos Gilberto (2008): Silvícolas, siringueros y agentes estatales: El surgimiento de una sociedad transfronteriza en la Amazonia de Brasil, Perú y Colombia, 1880-1932. (Bogotá, Universidad Nacional);

Zárate Botía, Carlos Gilberto ed. (2013): Hacia un CONPES Indígena Amazónico: construyendo una política pública integral para los pueblos indígenas de la Amazonía colombiana

Ziegler-Otero, Larry y Lawrence Ziegler-Otero (2004): Resistance in an Amazonian Community: Huaorani Organizing Against the Global ... Berghahn Books 
Artigo original

Hegemonia - Revista Eletrônica de Relações Internacionais do Centro Universitário Unieuro

ISSN: $1809-1261$

UNIEURO, Brasília, número Especial, 2016, pp. 121-174.

Zugaib, Eliana (2006): A HidroviaParaguai-Paraná e seu Significado para a Diplomacia Sul-Americana do Brasil (Brasilia: Fundação Alexandre de Gusmão, Funag)

Zuluaga Ramírez, Germán (2001): Unión de Chamanes en la Amazonía Colombiana, Etnoecológica Vol. 5 No. 7, 93-99pp

Zuluaga Ramírez, Germán (2005): Conservación de la Diversidad Biológica y Cultural en el Piedemonte Amazónico Colombiano: La herencia del Dr. Schultes, Ethnobotany Research \& Applications, vol.3, 167-177 www.ethnobotanyjournal.org/vol3/i1547-3465-03-167.pdf

Zuluaga Ramírez, Germán (2009): La historia del Vaupés desde esta orilla, Universidad del Rosario, 2009 